Universidade de São Paulo

Faculdade de Filosofia Ciências e Letras de Ribeirão Preto

Departamento de Química

Programa de Pós-Graduação em Química

\title{
AVALIAÇÃO DOS AGREGADOS ("CLUSTERS”) DA AMILOPECTINA EM SOLUÇÃO AQUOSA
}

Jacques Antonio de Miranda

Profa. Dra. Laura Tiemi Okano

Tese apresentada à Faculdade de Filosofia, Ciências e Letras de Ribeirão Preto da Universidade de São Paulo, como parte das exigências para a obtenção do título de Doutor em Ciências, Área: Química.

RIBEIRÃO PRETO, SP 2008 


Miranda, Jacques Antonio
Avaliação dos Agregados (“Clusters") da Amilopectina em
Solução Aquosa, 2008.
128 p. : il.; $30 \mathrm{~cm}$
Tese de doutorado, apresentada à faculdade de Filosofia,
Ciências e Letras de Ribeirão Preto/USP - Área de
concentração: Química.
Orientadora: Okano, Laura Tiemi.
1. Biopolímeros. 2. Amilopectina. 3. Sondas Fotofísicas.


Dedico este trabalho à minha mãe Zélia Natália de Miranda (in memorian), pelo exemplo e determinação em todos os momentos.

A todos aqueles que mesmo diante da negação do direito de ser gente resistem e lutam. 


\section{Agradecimentos}

À Deus, pela oportunidade de concluir mais uma etapa dessa breve passagem.

À minha orientadora Profa. Dra Laura Tiemi Okano pela compreensão, respeito, amizade. Nada que eu escreva poderá demonstrar o que você significou em minha formação. Desculpe-me pelas limitações e preocupações pessoais. Caso eu não mude algumas de minhas atitudes, acredite que você pelo menos me ajudou a tirar uma tarja preta dos olhos, que talvez me impedisse de enxergar melhor as responsabilidades daqueles que querem se dedicar à ciência.

Aos meus familiares, José Maria, Joaquim, José Mauro, José Maria Filho, obrigado pelo apoio, compreensão, dedicação e incentivo durante esta caminhada.

Aos amigos Alessandro Ferreira, Francisco Barra, Michel Bragança, Bruno e Alexandre pela torcida e incentivo.

Ao professor e incentivador Dr. Antonio Eduardo da Hora Machado, pela amizade e confiança.

À Lizandra e ao Daniel, pela paciência, pelos momentos de alegria e pela constante demonstração de amor e carinho.

À Olimpia Paschoal Martins pela amizade, auxílio nos experimentos e exemplo.

À Natacha Cacita pela ajuda nos experimentos e pelo convívio.

À Oxiteno pela cessão dos tensoativos utilizados neste trabalho.

Aos colegas do IBERLAAR, CBNSP e UNICERP pelo convívio e partilha de algumas angústias.

Aos professores Dr. Iouri Borissevitch e Dra. Maria Elisabete D. Zaniqueli pelas sugestões durante o exame de qualificação.

Ao Prof. Dr. Antônio Cláudio Tedesco e colegas do laboratório de Fotobiologia Daniela Manfrim, Patrícia Macaroff, Daniela Maranho, Alessandra, Renata, Vânia e Fernando Primo, Marcilene, Andreza, Angelo pelo convívio e empréstimo de equipamentos. 
Aos Prof. Dr. Amando Siuiti Ito e Dra. Maria Elisabete D. Zaniqueli pela disponibilização de equipamentos.

Ao Prof. Dr. Paulo Marcos Donate pelo cátion 2-benzoflavílio utilizado neste trabalho.

Aos Profs. Dr. Antonio Luis Maçanita do Instituto Superior Técnico da Universidade Técnica de Lisboa e Dr. João Carlos de Lima da Universidade Nova de Lisboa pela disponibilização dos equipamentos.

Aos colegas de grupo de pesquisa Daniel de Oliveira, Jean Balan, Mariana Guzzo, Cristina, Plínio, Marco Túlio, Andressa, João, Marília, pelo convívio, amizade e disponibilidade.

Ao amigo Fabiano de Almeida Silva, pelos experimentos em Uberlândia.

À todos os funcionários do Departamento de Química por toda a ajuda.

À todos aqueles que contribuíram direta e indiretamente na realização deste trabalho.

Ao CNPq e FAPESP pelo apoio financeiro ao grupo de pesquisa. 
"Professores e professoras são pedreiros que colocam tijolos no edifício de uma nova sociedade, que não será feroz e excludente como a atual. Mestres e mestras são anunciadores de um tempo de delicadeza, que já aparece no olhar curioso das crianças, no idealismo de seus jovens alunos. Ou dos adultos de mão calosas, que teimam em aprender. Profissionais do ensino são, necessariamente, militantes de um projeto rebelde e amoroso de regeneração do mundo." Pablo Gentili 


\section{RESUMO}

O interesse em estudar as estruturas e o comportamento em solução de biopolímeros reside no seu grande potencial de aplicação industrial como, por exemplo, agentes controladores de viscosidade em formulações farmacêuticas, alimentícias, entre outras. Estudos recentes, tendo em vista o aumento da biodegradabilidade de polímeros sintéticos, obtiveram razoável sucesso na associação de polímeros naturais, como o amido, com plásticos, como o polietileno de baixa densidade.

Neste trabalho, investigamos o microambiente da amilopectina na ausência e presença de tensoativos não-iônicos como o éter dodecil (7 e 23)-polioxietilênico (Unitol L-70 e L-230) e o nonilfenol (9,5)-polioxietilênico (Renex 95), por meio das propriedades físico-químicas de sondas de polaridade: pireno, xantona e Reichardt. Os estudos foram realizados através de técnicas espectroscópicas em estado estacionário (absorção de luz ultravioleta-visível e fluorescência) e resolvidas no tempo (baseadas na contagem de fótons únicos da emissão de fluorescência e na absorção triplete-triplete (T-T) e de intermediários reativos formados após a fotólise da amostra por pulso de laser). Estas técnicas forneceram os valores de: concentração de agregação crítica (cac), concentração micelar crítica $(\mathrm{cmc})$, número de agregação $\left(\mathrm{N}_{\mathrm{ag}}\right)$ e polaridade (escala py e $\mathrm{E}_{\mathrm{T}} 30$ ) para os sistemas avaliados.

Os dados obtidos foram comparados com as soluções contendo a presença ou não dos tensoativos não-iônicos e a carboximetil celulose $(\mathrm{CMC})$ e 2-hidroxietil amido (2-HEAM). Por fim, a estabilidade do cátion 2-fenilbenzopirílio foi avaliada em diferentes solventes orgânicos, nas micelas dos tensoativos estudados, nos biopolímeros e nos complexos biopolímero-tensoativo.

Dois procedimentos experimentais diferentes foram adotados para o preparo das soluções de amilopectina. As diferenças na preparação das soluções de amilopectina tornaram evidente que este biopolímero possui diferentes ambientes para a localização das sondas. Estas diferenças não foram observadas na presença de CMC e de 2-HEAM.

Os resultados experimentais confirmaram a interação cooperativa entre a amilopectina e os tensoativos Unitol L-70 e L-230. Esta interação é menos 
pronunciada para os sistemas formados entre os tensoativos e 2-HEAM e desfavorecidos na presença de CMC.

Nos experimentos onde foi avaliado o equilíbrio monômero-excímero do pireno, verificou-se que os complexos amilopectina-tensoativo agrupam um número maior de moléculas de pireno do que os clusters de amilopectina sozinhos. Estes ambientes favoreceram ambos os movimentos de rotação e translação entre as moléculas, para a formação do excímero.

Os estudos resolvidos no tempo, utilizando a xantona como sonda fotofísica para as técnicas de fluorescência resolvida no tempo ou de fotólise por pulso de laser, demonstraram que na amilopectina, a sonda ocupa preferencialmente o ambiente aquoso, ao invés dos microambientes internos do polímero. Isto possivelmente é uma decorrência da proteção das cadeias ramificadas do seu esqueleto polimérico. Estes mesmos estudos indicaram que na presença de concentrações mais elevadas de CMC, a xantona migra do seio da solução aquosa para ambientes próximos à cadeia polimérica onde podem ocorrer sua protonação ou associação em sítios não protonados.

Em relação à estabilização do cátion 2-fenilbenzopirílio, nas condições estudadas envolvendo tanto os biopolímeros quanto os sistemas biopolímerotensoativo, predominaram os isômeros da chalcona. Os maiores tempos de meiavida foram observados em CMC, o que pode ser justificado pela maior viscosidade do meio. 


\section{ABSTRACT}

Nowadays in literature, there have been several papers studying the structure and behavior of biopolymers solutions, since these materials encounter a large application field in industry such as the viscosity agent in several pharmaceutical and food products, among many others. For instance, recently, some researchers have had success in increasing the biodegradability of synthetic polymers, adding starch to low density polyethylene.

In this work, the amylopectin microenvironment was studied in the presence and absence of the non-ionic surfactants polyoxyethylene (7 and 23 ) dodecyl ether (Unitol L-70, and L-230, respectively) and polyoxytethylene (9.5) nonylphenol ether (Renex 95), through the physical-chemical properties of the polarity probes: pyrene, xanthone, and Reichardt. Steady-state (UV-visible absorption, and fluorescence), and time-resolved (time-correlated single photon counting fluorometry, and laser flash photolysis) techniques were used to evaluate the critical aggregation concentration (cac), critical micellar concentration $(\mathrm{cmc})$, average micellar aggregation numbers $\left(\mathrm{N}_{\mathrm{ag}}\right)$, and polarity ( $p y$, and $\mathrm{E}_{\mathrm{T}} 30$ scales) of the complexes of amylopectin-non-ionic surfactants. The amylopectin experimental results were compared with the obtained ones from aqueous solutions of carboxymethyl cellulose (CMC) and 2-hydroxyethyl starch (2-HEAM) in the absence and presence of nonionic surfactants. The stability of 2-phenylbenzopyrilium cation was also investigated in several organic solvents, in the non-ionic surfactant micelles, in the biopolymers and in the complexes of biopolymer-surfactants.

The amylopectin aqueous solutions were prepared by two different experimental procedures. The determined results of the relative intensities of pyrene fluorescence emission bands 1 to 3 , and excimer and monomer ratio have pointed out that the amylopectin presents different microenvironments for photophysical probes relocation. Such differences were not observed in the presence of CMC and 2-HEAM.

The cooperative interaction between the amylopectin, and the Unitol-L70 and L230 surfactants were comproved by the experimental results. The complexes of 2HEAM-non-ionic surfactant were less stable than the amylopectin ones, while CMC does not form complexes of biopolymer-surfactants. 
The single-photon timing and laser flash photolysis techniques employing xanthone as probe have shown that this probe remains at the aqueous bulk of the amylopectin solutions. There is no interaction between xanthone and the amylopectin backbone, probably due to the great extent of the polymeric branching. On the other hand, in presence of higher concentrations of CMC solutions, xanthone can relocate from the aqueous solution to the polymeric microenvironment, where the probe can be or not protonated.

The evaluation of the stability of 2-phenylbenzopyrilium cation in the presence of biopolymer or complexes of biopolymer-surfactants has shown the predominance of the chalcone isomers. The higher half-life times were determined in the CMC because of the higher viscosity of the medium. 


\section{LISTA DE FIGURAS}

FIGURA 1. Representação estrutural de um fragmento de amilose .22

FIGURA 2. Representação para o empacotamento dos biopolímeros constituintes do amido.

FIGURA 3. Representação estrutural de um fragmento de amilopectina. .23

FIGURA 4. (a) torção das ligações entre as unidades de glicose nos biopolímeros do amido. (b) estrutura helicoidal resultante na amilose.

FIGURA 5. Micrografia eletrônica de varredura de grânulos de amido aquecidos. Barra de escala de $20 \mu \mathrm{m}$. (TESTER, KARKALAS \& QI, 2004). 25

FIGURA 6. Representação esquemática dos níveis de organização do grão de amido e seus biopolímeros. (BULÉON et al., 1998)... 27

FIGURA 7. Modos de organização das moléculas de tensoativo para a diminuição das energias interfacial e superficial. $(L=$ líquido, $V=$ vapor, S = sólido) (MYERS, 1999)......

FIGURA 8. Diagrama de Jablonski. 35

FIGURA 9. Estrutura do corante de Reichardt, utilizado como padrão de polaridade. 39

FIGURA 10. Derivado do corante de Reichardt utilizado para estudos em solventes de baixa polaridade. 41

FIGURA 11. Esquema representativo para a formação do exímero do pireno...42 
FIGURA 12. Espectro de emissão de fluorescência do pireno. (TURRO, 1991) ....43

FIGURA 13. Representação das equações envolvidas para a oenina, uma antocianina natural (MARKAKIS, 1992). .45

FIGURA 14. Estrutura do cátion 2-fenilbenzopirílio. .46

FIGURA 15. Estruturas dos tensoativos utilizados. 49

FIGURA 16. Espectro de emissão de fluorescência do pireno em (A) amilopectina 1\%, na presença de (B) Unitol L-70 1,0 mmol.L ${ }^{-1}$, and (C) $2,0 \mathrm{mmol} \cdot \mathrm{L}^{-1}$, a $25^{\circ} \mathrm{C}$. (I) pireno foi adicionado após o resfriamento as solução de amilopectina; (II) pireno e amilopectina foram aquecidos juntos. 58

FIGURA 17. Espectro de emissão de fluorescência do pireno em amilopectina $1 \%$.. (linha contínua) pireno foi adicionado após o resfriamento as solução de amilopectina; (linha tracejada) pireno e amilopectina foram aquecidos juntos. 58

FIGURA 18. Estrutura seca (nemático) (b) Estrutura esmética hidratada (WAIGH et al., 2000).

FIGURA 19. Esquema ilustrativo das hélices hidratadas (WAIGH et al., 1998)..60

FIGURA 20. Intensidade relativa das bandas $1 / 3$ de emissão do pireno em função de: (A) concentração de surfactante não-iônico ( $\mathbf{\square}$, Renex 95; •, Unitol L-70, e $\boldsymbol{\Delta}$, L-230); e (B) Unitol L-230 em soluções aquosas de amilopectina $(\square, 0,2 \% ; \bullet, 1,0 \%)$, a $25^{\circ} \mathrm{C}$. 62

FIGURA 21. Gráficos da razão 1/3 e excimero/monomero do pireno em função de Unitol L-70, Unitol L-230, Renex 95 em soluções com diferentes concentrações de 2-hidroxietilamido. Pireno foi adicionado durante o preparo da solução. 66

FIGURA 22. Interações entre as unidades de glicose nos biopolímeros de celulose. (b) conformação em camadas sobrepostas dos derivados de celulose. 
FIGURA 23. Gráficos da razão 1/3 e excimero/monomero do pireno em função de (A) Unitol L-230, (B) Unitol L-70, (C) Renex 95 em soluções com diferentes concentrações de carboximetilcelulose. Pireno foi adicionado durante o preparo da solução. 68

FIGURA 24. Gráficos da razão excímero/monômero do pireno em função de (A) Unitol L-230, (B) Unitol L-70, (C) Renex 95 em soluções de amilopectina ( - 0,2\%; - 1,0\%). (ESQUERDA) Pireno foi adicionado após o resfriamento da solução. (DIREITA) Pireno foi adicionado durante o preparo da solução. 69

FIGURA 25. Gráficos dos decaimentos cinético de fluorescência do pireno $(1 \mu \mathrm{M})$ em função dos comprimentos de onda de emissão em (A) Unitol L$230-0,3 \mathrm{mmol} / \mathrm{L}$, (B) Unitol L-230 - 0,9 mmol/L, (C) Unitol L-230 $1,8 \mathrm{mmol} / \mathrm{L}$ em soluções de amilopectina $1,0 \%$. Pireno foi adicionado durante o preparo da solução. (D) Decaimentos cinéticos do pireno, destacando a emissão do monômero e do excímero (TURRO, 1991) .........................................................72

FIGURA 26. Gráfico da supressão de emissão de fluorescência do pireno em Unitol L-230 ( $\square, 0 ; 0,0.4 ;-, 0.6 ; \diamond, 0.8$; and $\bullet, 1,0 \%)$

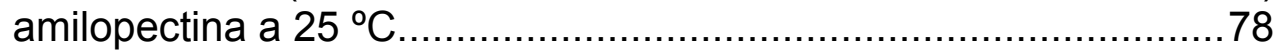

FIGURA 27. Espectros de emissão de fluorescência da xantona em água e em diferentes concentrações de amilopectina, exc $=340 \mathrm{~nm}$. $\mathrm{f} 1=\mathrm{f} 2=5$ nm. (A) Agitação por 24 horas; (B) Agitação por 72 horas. .83

FIGURA 28. Razão Io/l (Intensidade de fluorescência em $392 \mathrm{~nm}$ de solução saturada de xantona em água $\left(\mathrm{I}_{0}\right)$ e na presença de amilopectina(I)). (A) Agitação por 24 horas, (B) por 72 horas. ........83

FIGURA 29. Decaimentos cinéticos de fluorescência da xantona na ausência e presença de diferentes concentrações de amilopectina. (A) em água, (B) 0,2 ; (C) 0,5 ; (D) 0,7; (E) 1,0 e (F) 1,2\% de amilopectina. 85

FIGURA 30. Análise global da xantona na presença de concentração variável de amilopectina. .86

FIGURA 31. Relação entre componentes do tempo de vida da xantona em função da concentração da amilopectina. 
FIGURA 32. Relação entre as amplitudes dos componentes do tempo de vida da xantona em função da concentração da amilopectina.

FIGURA 33. Esquema utilizado na análise do tempo de vida da xantona na presença de amilopectina e na fase aquosa.

FIGURA 34. Ajuste de acordo com o modelo para descrição das amplitudes normalizadas e determinação das constantes de velocidade de desativação do estado excitado singlete da xantona presente em soluções de amilopectina (linha contínua ou pontilhada, valores calculados frente aos dados experimentais

FIGURA 35. Espectro de absorção T-T da xantona em $0,1 \%$ amilopectina registrado em (A) 20 ns e (B) $2 \mu$ s por divisão. .95

FIGURA 36. Espectro normalizado de absorção T-T da xantona em 0,1\% amilopectina registrado após $(\bullet)$ 27,5 ns e (ロ 1,15 $\mu$ s após a excitação do pulso de laser. 95

FIGURA 37. Espectro de absorção T-T da xantona em 0,5\% amilopectina registrado em (A) 20 ns e (B) $5 \mu$ s por divisão.

FIGURA 38. Espectro normalizado de absorção T-T da xantona em 0,5\% amilopectina registrado após $(\bullet)$ 27,5 ns e (ロ 2,89 $\mu$ s após a excitação do pulso de laser. 96

FIGURA 39. Espectro de absorção T-T da xantona em 1,0\% amilopectina registrado em (A) 50 ns e (B) $2 \mu$ s por divisão. .96

FIGURA 40. Espectro normalizado de absorção T-T da xantona em 1,0\%

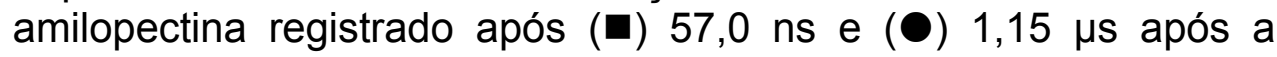
excitação do pulso de laser.

FIGURA 41. Espectro normalizado de absorção T-T da xantona em água (ロ, 5,8 $\mu \mathrm{s})$ e em $0,1 \%(\boldsymbol{\square}, 1,15 \mu \mathrm{s}), 0,5 \%(\bullet, 2,89 \mu \mathrm{s})$ e $1,0 \%(\boldsymbol{\Lambda}, 1,57 \mu \mathrm{s})$ de amilopectina após a excitação do pulso de laser.

FIGURA 42. Espectros de fluorescência da xantona ${ }^{1}$ em concentração variável de CMC, $\lambda_{\text {exc. }}=320 \mathrm{~nm}$. 
FIGURA 43. Decaimentos de fluorescência da xantona na ausência e presença de diferentes concentrações de CMC (A) em água, (B) 0,2; (C) 0,5; (D) 0,$7 ;$ (E) 1,0 e (F) $1,2 \%$ de CMC. 101

FIGURA 44. Decaimentos de fluorescência da xantona na ausência e presença de diferentes concentrações de CMC (A) $3 \%$ de CMC, (B) $2 \%$ de CMC. 102

FIGURA 45. Análise global da xantona em na presença de concentração variável de carboximetil celulose. 103

FIGURA 46. Gráfico do tempo de vida da xantona experimentalmente determinado na presença de concentração variável de monômeros de CMC. 104

FIGURA 47. Gráfico das amplitudes normalizadas em função da concentração do monômero da CMC. (A) $390 \mathrm{~nm}$ e (B) $475 \mathrm{~nm}$. 105

FIGURA 48. Análise dos decaimentos de fluorescência utilizando o método de entropia máxima $(\mathrm{A}) \mathrm{CMC}$ e (B) amilopectina. 107

FIGURA 49. (I) espectros de absorção molecular do cátion flavílio em acetonitrila não-tamponada. (II) Absorvâncias normalizadas do cátion flavílio monitoradas a (A) $394 \mathrm{~nm},(B) 244 \mathrm{~nm}$ e (C) $314 \mathrm{~nm}$. 109

FIGURA 50. Espectros de absorção molecular do cátion flavílio em meio aquoso. $\mathrm{HA}^{+}\left(\lambda_{\max }=394 \mathrm{~nm}\right), \mathrm{C}_{\mathrm{t}}\left(\lambda_{\max }=352 \mathrm{~nm}\right), \mathrm{B}\left(\lambda_{\max }=262 \mathrm{~nm}\right), \mathrm{C}_{\mathrm{c}}\left(\lambda_{\max }\right.$ $=304 \mathrm{~nm}$ ) 110 


\section{LISTA DE TABELAS}

TABELA 1. Características típicas da amilose e amilopectina .23

TABELA 2. Razão $1 / 3$ do pireno presença de amilopectina a várias concentrações e diferentes procedimentos de preparação da solução de biopolímero, a $25^{\circ} \mathrm{C}$ .57

TABELA 3. cac, cmc e $N_{a}$ para os surfactantes não-iônicos na presença de amilopectina a várias concentrações e diferentes procedimentos de preparação da solução de biopolímero, a $25^{\circ} \mathrm{C}$ 61

TABELA 4. Cac, cmc e $\mathrm{N}$ para soluções de surfactantes não-iônicos com biopolímeros, a $25^{\circ} \mathrm{C}$.

TABELA 5. Tempo de vida de fluorescência e amplitudes do pireno, em diferentes concentrações de Unitol L-230 e amilopectina 0,2\%, monitorados em diferentes comprimentos de onda de emissão.....73

TABELA 6. Comprimentos de onda máximos de absorção de soluções do corante de Reichardt, a $25^{\circ} \mathrm{C}$.

TABELA 7. N para o sistema tensoativo Unitol/amilopectina, empregando o procedimento de aquecimento da sonda e do biopolímero. .78

TABELA 8. Cmc e energia livre de Gibbs para o processo de micelização a diferentes temperaturas. .80

TABELA 9. Valores de tempo de vida da xantona na presença de concentração variável de amilopectina

TABELA 10. Valores das amplitudes (A) dos tempos de vida da xantona na presença de concentração variável de amilopectina, e os valores normalizados $\left(A_{n}\right)$. .88 
TABELA 11. Valores determinados de acordo com o modelo descrito em Noronha et al. 2004, para análise das amplitudes dos tempos de vida da xantona na presença de concentração variável de amilopectina.

TABELA 12. Valor do tempo de vida do estado triplete da xantona na presença de concentração variável de amilopectina, a $580 \mathrm{~nm}$.

TABELA 13. Tempos de vida da xantona presente em concentração vairável de CMC. 103

TABELA 14. Valores normalizados das amplitudes determinadas para cada comprimento de onda analisado. 105

TABELA 15. Tempos de meia-vida do cátion flavílio e em diferentes meios de dispersão. 


\section{SUMÁRIO}

CAPÍTULO 1

INTRODUÇÃO

1.1. O AMIDO

1.1.1. COMPOSIÇÃO, ORGANIZAÇÃO E APLICAÇÕES ...................................21

1.2. SURFACTANTES E SUAS INTERAÇÕES COM OS COMPONENTES DO



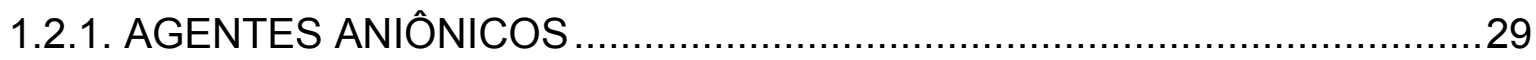

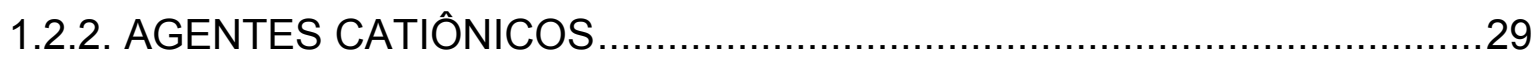

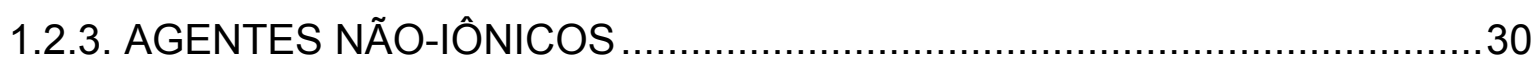

1.2.4. A DISPERSÃO DOS TENSOATIVOS EM ÁGUA. .....................................31

1.2.5. AMIDO E SUAS INTERAÇÕES COM SURFACTANTES ............................32

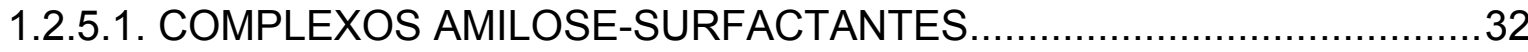

1.2.5.2. COMPLEXOS AMILOPECTINA-SURFACTANTE ................................34

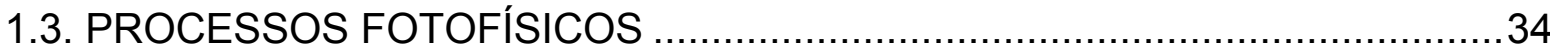

1.3.1. PRINCÍPIOS DE FOTOFÍSICA ORGÂNICA ………...............................34

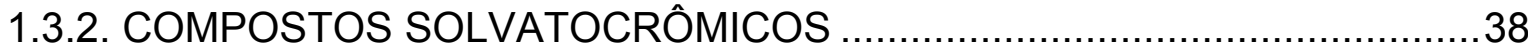

1.4. CÁTION FLAVÍLIO: UMA ESPÉCIE DE INTERESSE .................................44

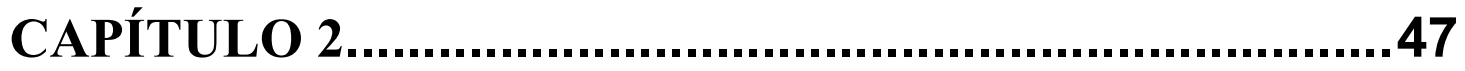

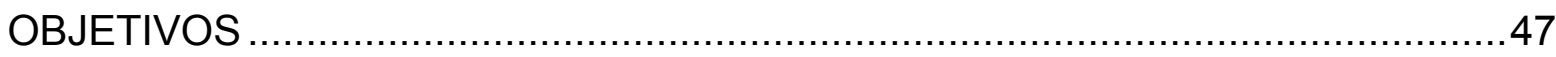


CAPÍTULO 3

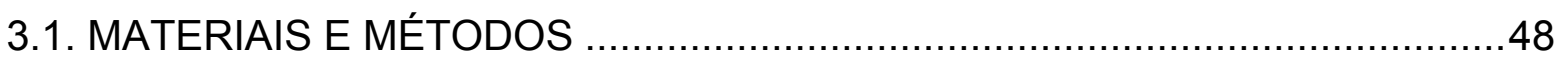

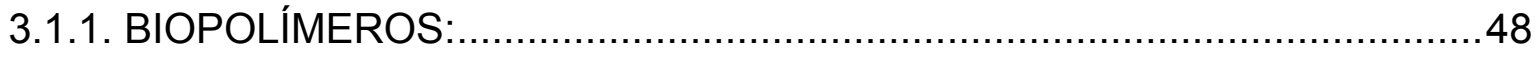

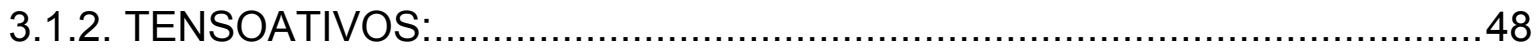

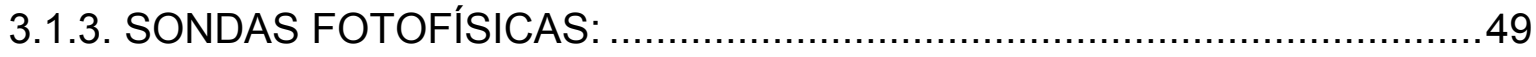

3.1.4. SOLVENTES E REAGENTES DIVERSOS: $\ldots \ldots \ldots \ldots \ldots \ldots \ldots \ldots \ldots \ldots \ldots \ldots . \ldots \ldots$

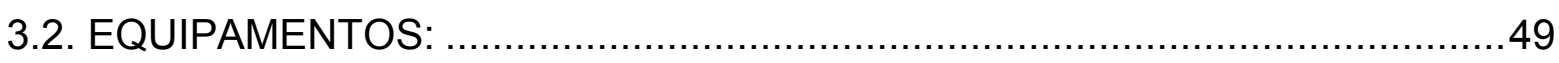

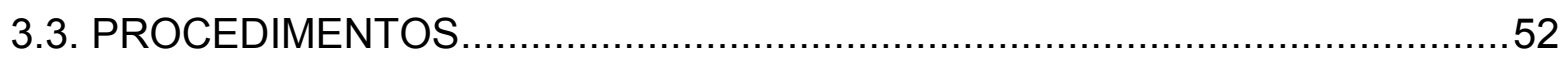

3.3.1. PURIFICAÇÃO DAS SONDAS SOLVATOFLUORESCENTES ................52

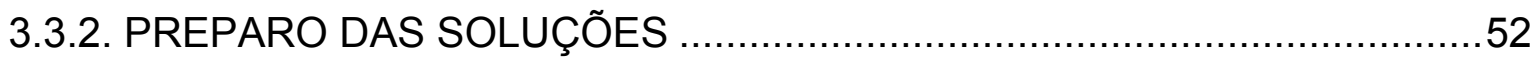

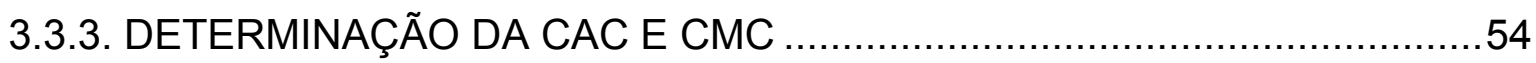

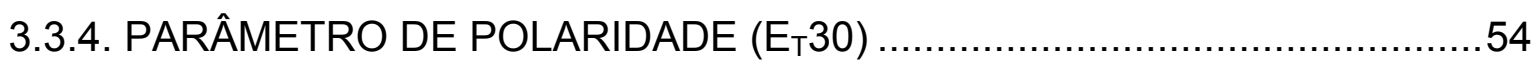

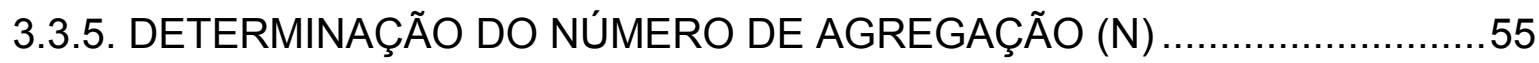

3.3.6. ESTABILIDADE DO CÁTION FLAVÍLIO ........................................... 55

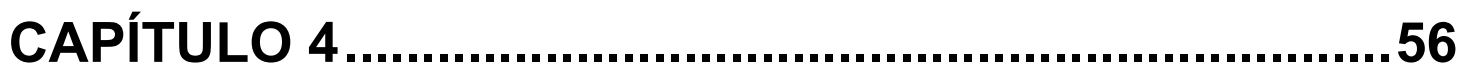

4.1. A ASSOCIAÇÃO COOPERATIVA ENTRE OS SURFACTANTES NÃO IÔNICOS E OS COMPONENTES DO AMIDO AVALIADA POR MEIO DA

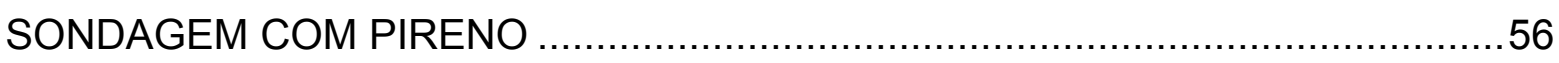

4.1.1. A RAZÃO 1/3 DO PIRENO. DETERMINAÇÃO DA CMC E CAC...............60

4.1.2. A RAZÃO EXCÍMERO/MONÔMERO DO PIRENO ...............................69

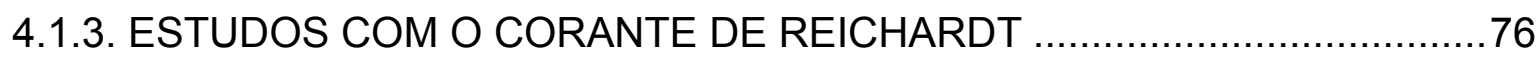

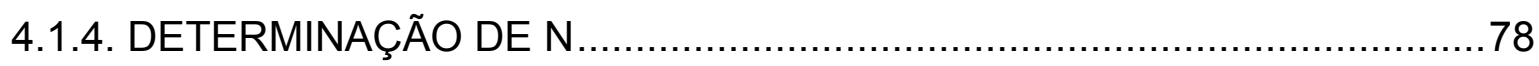

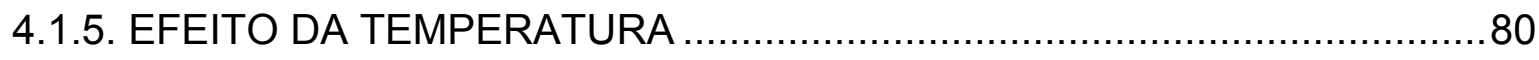


CAPÍTULO 5.

5.1 COMPORTAMENTO FOTOFÍSICO DA XANTONA EM SOLUÇÕES DE AMILOPECTINA 82

5.1.1. MEDIDAS DE FLUORESCÊNCIA EM PICOSEGUNDOS DA XANTONA EM SOLUÇÕES AQUOSAS DE AMILOPECTINA .84

5.1.2. MEDIDAS DO ESTADO EXCITADO TRIPLETE DA XANTONA EM SOLUÇÕES AQUOSAS DE AMILOPECTINA. .93

5.2. INTERAÇÃO DA XANTONA EM SOLUÇÕES AQUOSAS DE CARBOXIMETILCELULOSE. .99

CAPÍTULO 6 108

6.1. A ESTABILIZAÇÃO DO CÁTION FLAVÍLIO 108

CONCULSÕES 116 REFERÊNCIAS BIBLIOGRÁFICAS 118 


\section{CAPÍTULO 1}

\section{INTRODUÇÃO}

Polímeros naturais são compostos derivados de recursos naturais como plantas, animais e fermentação bacteriana. Possuem menor estabilidade à elevação de temperatura e menor tolerância a biodegradação que os sintéticos. Esta rapidez da deterioração confere a estes materiais um caráter mais ecológico. Os polímeros naturais que apresentam maior interesse comercial são resultantes da polimerização de moléculas de açúcar, os polissacarídeos. A polimerização das unidades de açúcar, monômero dos polissacarídeos, ocorre por meio de reações de condensação com remoção da água. O polissacarídeo resultante consiste nas unidades de açúcar ligadas entre si por átomos de oxigênio comuns. A cadeia principal destes polímeros naturais é mais complexa que os sintéticos, sendo constituída de carboidratos de estrutura anelar e os átomos de oxigênio que ligam os anéis entre si. Polímeros sintéticos têm ligações $\mathrm{C}-\mathrm{C}$ muito mais simples e resistentes (daí sua menor biodegradabilidade) (KROG, 1973).

Exemplos típicos destas espécies químicas podem ser enumerados de acordo com cada fonte natural de obtenção, sendo os mais conhecidos o amido, o glicogênio e a celulose. Ao longo dos anos, vários esforços têm sido direcionados à compreensão da estrutura e das propriedades industriais dos biopolímeros. Durante 
Capítulo 1

os últimos quatro anos, direcionamos nossa atenção à caracterização dos polímeros formadores do amido, em especial, a amilopectina, utilizando-se para isto, sondas e técnicas fotofísicas em estado estacionário e resolvidas no tempo. Por este motivo, esta introdução apresenta a seguir uma breve revisão bibliográfica abordando diferentes tópicos em relação ao estudo dos biopolímeros formadores do amido, a química envolvida no trabalho com tensoativos, suas interações com o amido e uma descrição sobre alguns princípios físico-químicos referentes aos processos fotofísicos e sondas utilizadas neste trabalho.

\subsection{O AMIDO}

\subsubsection{COMPOSIÇÃO, ORGANIZAÇÃO E APLICAÇÕES}

A amilose e a amilopectina são os dois polissacarídeos formadores do amido. A amilose (FIGURA 1) é um polímero essencialmente linear constituído por unidades a-ligadas de anidroglicose, sendo 99\% (1-4) e aproximadamente 1\% (1-6) (KROG, 1973; NIERLE \& EL BAYA, 1990)

Por sua vez, a amilopectina é uma molécula muito maior, com peso molecular típico (MW) na escala de $10^{8} \mathrm{~g} / \mathrm{mol}$, fortemente ramificada e compacta que contém unidades $\alpha$-ligadas de anidroglicose, sendo cerca de $95 \%$ de ligações $\alpha-(1-4)$ e $5 \%$ a-(1-6') (FIGURA 2). Os modelos atuais propõem que a estrutura da amilopectina é composta por cadeias lineares curtas, com 10 a 20 unidades de anidroglicose, arranjadas em conjunto de cadeias mais longas (FIGURA 3). O tamanho, a forma, a estrutura e a polidispersão molecular de ambos bioplímeros variam de acordo com a origem do amido. A Tabela 1 descreve algumas das características dos biopolímeros do amido. 
Capítulo 1

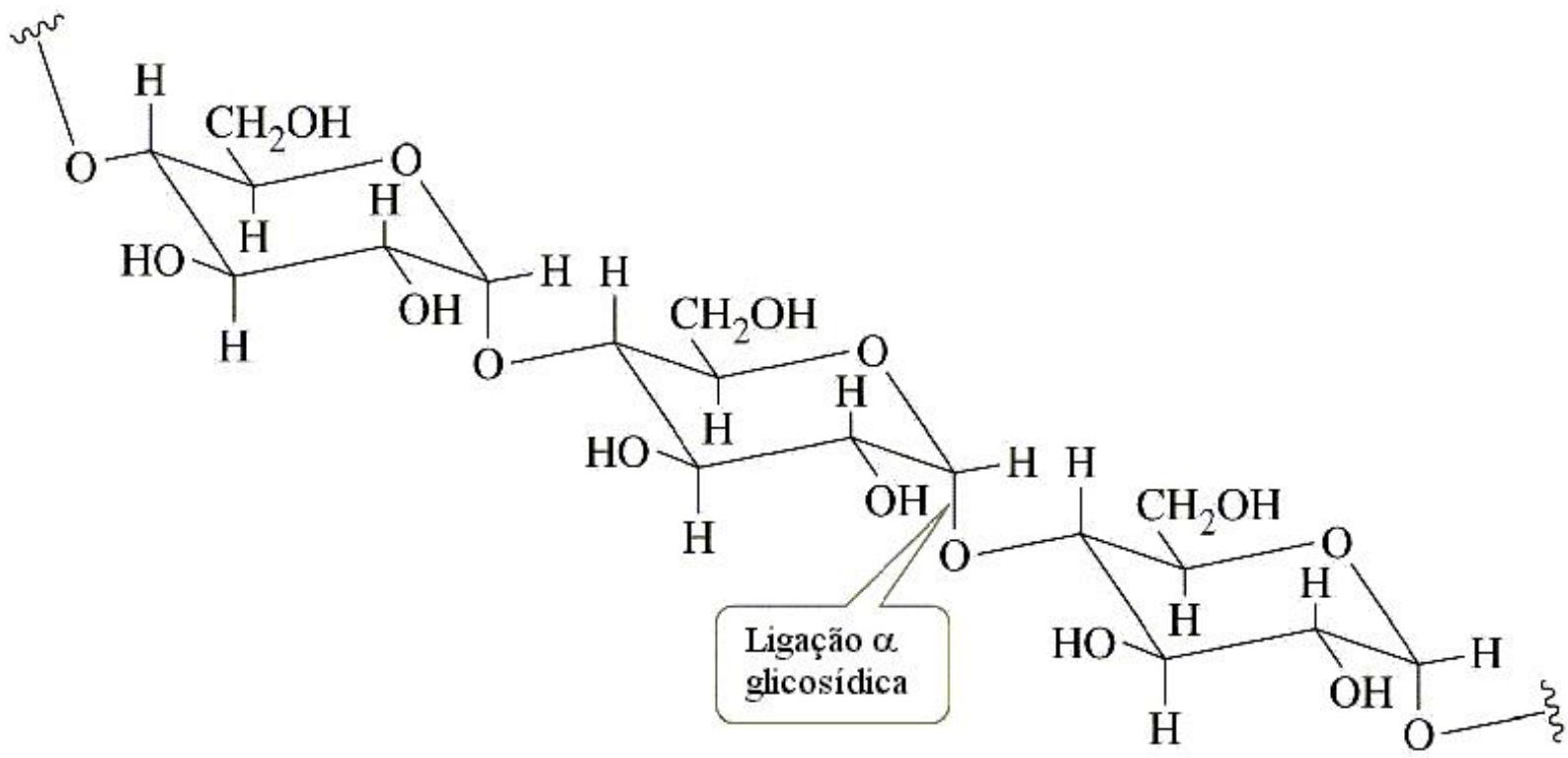

FIGURA 1. Representação estrutural de um fragmento de amilose.

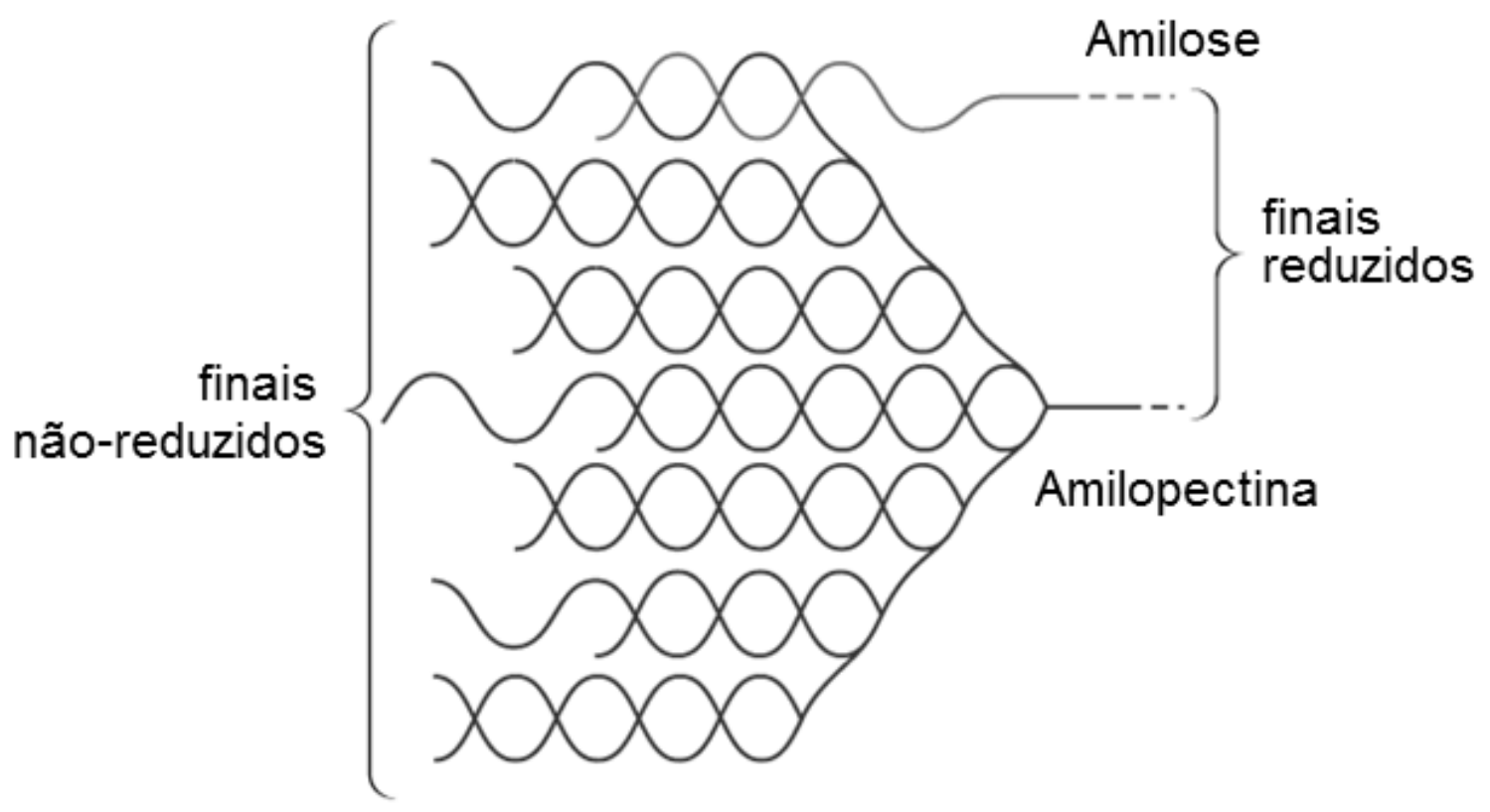

FIGURA 2. Representação para o empacotamento dos biopolímeros constituintes do amido. 


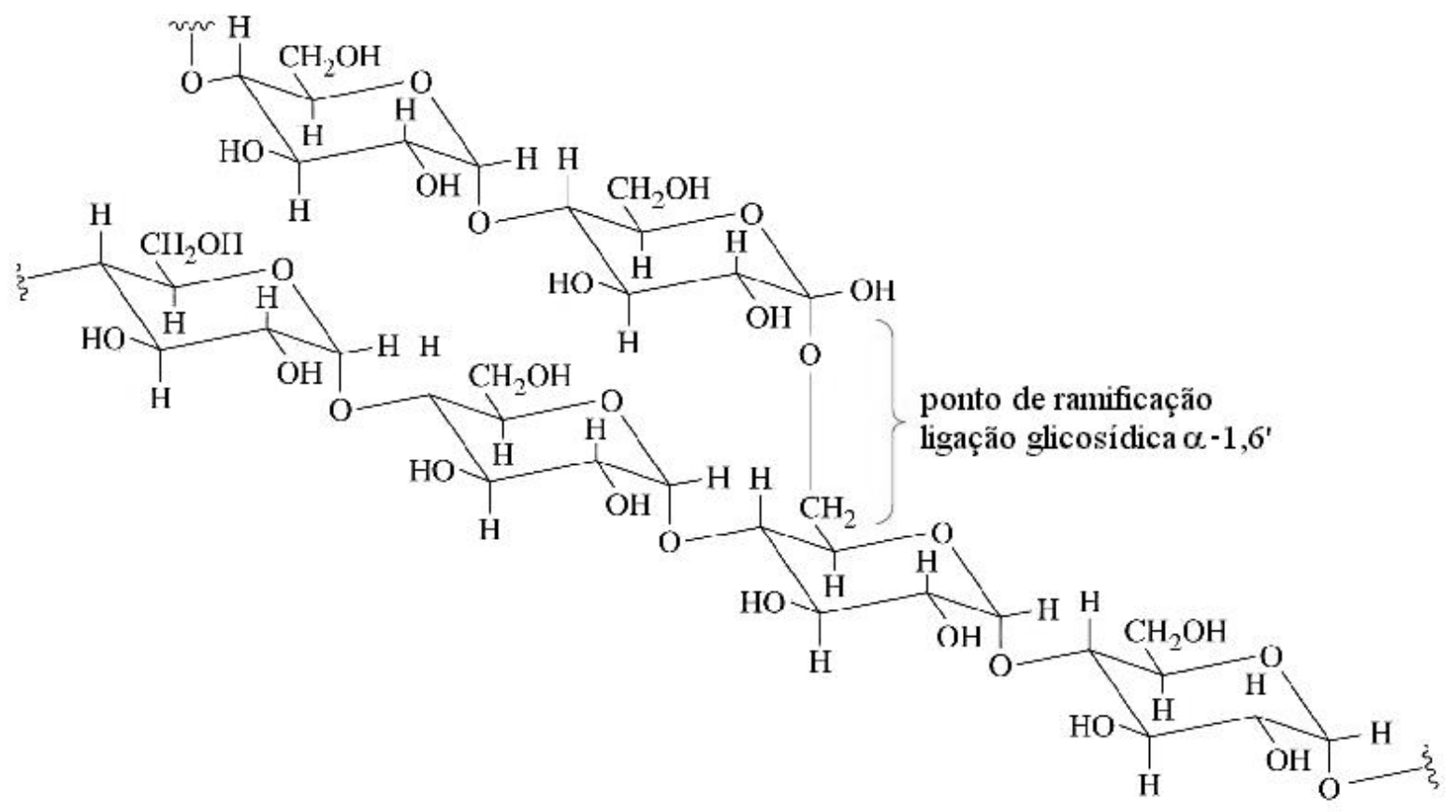

FIGURA 3. Representação estrutural de um fragmento de amilopectina.

TABELA 1. Características típicas da amilose e amilopectina

Propriedade $^{\mathrm{a}} \quad$ Amilopectina Amilose

\begin{tabular}{lll}
\hline Estrutura molecular & Altamente ramificada & Essencialmente linear \\
Massa molar $(\mathrm{g} / \mathrm{mol})$ & $1 \times 10^{6}-1 \times 10^{9}$ & $1 \times 10^{5}-1 \times 10^{6}$ \\
Grau de polimerização & $9600-15900$ & $320-4900$ \\
$\mathrm{~N}^{0}$ de unidades de glicose & $12-23$ nas cadeias curtas & Aproximadamente 1000 \\
por cadeia & $20-120$ nas cadeias \\
& longas
\end{tabular}

${ }^{a}$ TESTER; MORRISON, 1990

Nos polissacarídeos do amido, as a-hélices (de 1-4) dão uma torção gradual às moléculas de glicose, afetando fortemente seu comportamento em solução. A conformação da amilose em solução, por muito tempo, tem sido o assunto de várias pesquisas e é ainda carregada de controvérsias (TUFVESSON, WAHLGREN, \& ELIASSON, 2003; BULÉON et al., 1998; TESTER, KARKALAS \& QI, 2004; PARKER \& RING, 2001). A sugestão atual para soluções aquosas neutras de amilose é a de uma conformação média que se assemelha a uma bobina altamente desordenada 
que envolve muitas seqüências de estruturas helicoidais curtas irregulares e lábeis (BILIADERIS, 1998).

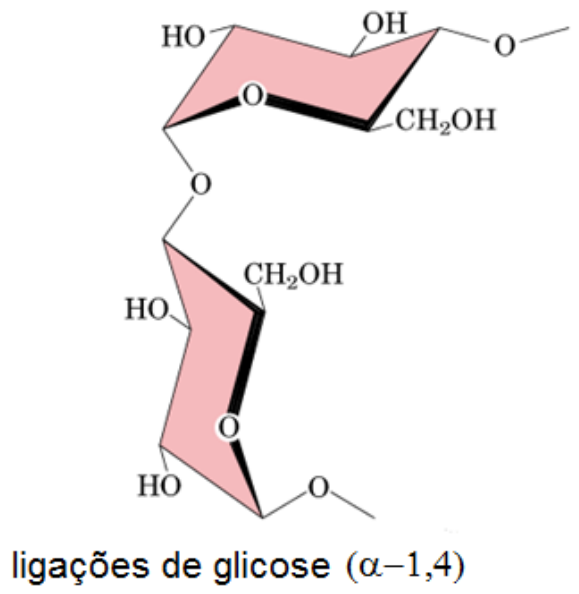

(a)

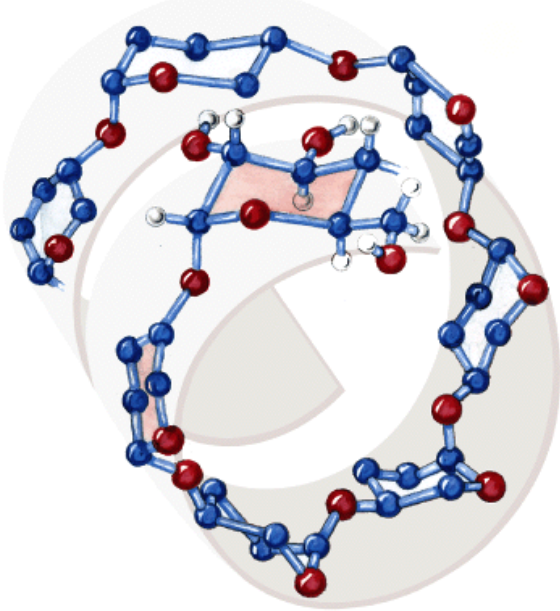

(b)

FIGURA 4. (a) torção das ligações entre as unidades de glicose nos biopolímeros do amido. (b) estrutura helicoidal resultante na amilose.

Tal conformação sugere a possibilidade em aplicar estas soluções em complexos helicoidais de inclusão na presença de um ligante apropriado (ELIASSON \& LARSSON, 1993). Um dos mais bem conhecidos complexos é o formado por uma unidade de amilose cercado por vários íons iodetos em solução aquosa (YAMAMOTO, SANO \& YASUNAGA, 1982). Nesta associação, amilose e iodeto formam um complexo azul-escuro que configura uma cor azul característica. Já a habilidade da amilopectina de dar forma a tais complexos é muito mais restrita e a associação desta molécula com iodo resulta em uma solução marrom-avermelhada. Esta diferença é a base para um dos métodos mais extensamente usado para a identificação dos dois biopolímeros.

Outra característica da amilose em solução está relacionada com o interrelacionamento entre as cadeias do biopolímero. Isto faz com que as soluções da amilose sejam mais instáveis quando comparadas às soluções de amilopectina (ZOBEL, 1988). A ocorrência das associações intramoleculares da amilose resulta também no fenômeno denominado retrogradação (COLLISON, 1968). Ele ocorre durante a refrigeração de soluções aquosas quentes de amilose, quando submetidas a temperaturas superiores a $130^{\circ} \mathrm{C}$ (COLLISON, 1968; BANKS \& GREENWOOD, 1975; MILES, MORRIS \& RING, 1984). 
Capítulo 1

Quando submetidos a uma concentração crítica (cerca de $1 \% \mathrm{~m} / \mathrm{m}$ para amilose (GIDLEY \& BULPIN, 1989) e de aproximadamente $20 \% \mathrm{~m} / \mathrm{m}$ para a amilopectina (NOEL, RING \& WHITMAN, 1993)) os dois biopolímeros têm uma tendência a formar géis. A gelatinização ocorre em conseqüência da formação de uma rede interconectada. A associação e/ou a cristalização molecular que ocorre nos géis resulta em ligações de hidrogênio transversais. Tais interações são interessantes pois proporcionam géis com diferente resistência à tensão (amilose forma géis mais duros e amilopectina mais macios).

\section{Composição}

Os grânulos de amido podem ser encontrados sob uma variedade de tamanhos (aproximadamente de 1 a $100 \mu \mathrm{m}$ de diâmetro), formas (redondo, lenticular, poligonal) e distribuições de tamanho (uni- ou bimodal) dependendo da fonte de obtenção. A FIGURA 5 representa uma micrografia de uma amostra de amido de trigo.

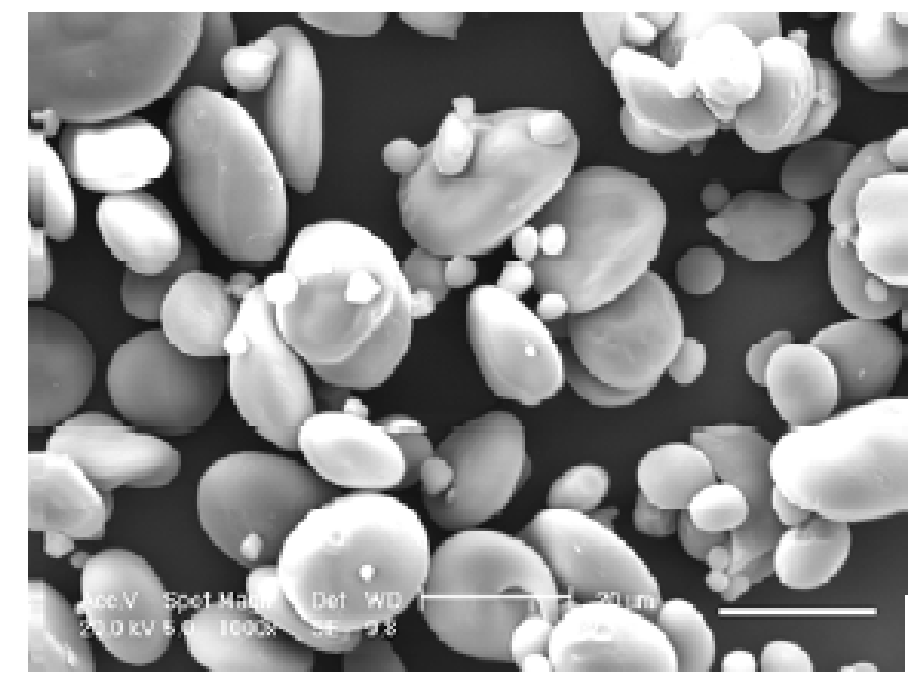

FIGURA 5. Micrografia eletrônica de varredura de grânulos de amido aquecidos. Barra de escala de $20 \mu \mathrm{m}$. (TESTER, KARKALAS \& QI, 2004).

Os dois biopolímeros do amido representam cerca de 98 a $99 \%$ do peso seco do grão, com proporção dependente da fonte. De acordo com seu índice de amilose, os amidos podem ser classificados como "maisena" (menos de 15\% amilose), "normal" (20-35\% amilose) e amidos "elevados" de amilose (mais que 40\% amilose) (TESTER, KARKALAS \& QI, 2004). 
Os componentes menores do amido consistem principalmente de lipídeos e proteínas. Apesar de estarem presentes em quantidades pequenas, os lipídeos e as proteínas têm efeitos importantes na funcionalidade dos grânulos (TESTER \& MORRISON, 1990; NIERLE et al., 1990; DEBET \& GIDLEY, 2006).

Os lipídios, geralmente encontrados na maior parte dos amidos cereais, correlacionam-se com o índice de amilose e podem representar cerca de 1,5\% do grânulo. Existem lipídeos na superfície do grânulo (MORRISON, 1981), principalmente os triglicerídeos, os ácidos graxos livres, os glicolipídeos e os fosfolipídeos (MORRISON, 1981; VASANTHAN \& HOOVER, 1992), e lipídeos internos, que consistem essencialmente de lisofosfolipídeos (VASANTHAN \& HOOVER, 1992) e ácidos graxos livres (TAKAHASHI \& SEIB, 1988). Já o índice de proteínas é menor que $0,6 \%$. Da mesma forma, as proteínas ocorrem na superfície e dentro da matriz dos grânulos. As proteínas internas têm um peso molecular mais elevado do que as encontradas na superfície (50-150 kDa e 15-30 kDa, respectivamente) e incluem resíduos de enzimas envolvidas na síntese do amido, especialmente a amido sintetase (BALDWIN, 2001). Contém também quantidades relativamente pequenas $(<0,4 \%)$ de minerais tais como: cálcio, magnésio, fósforo, potássio e sódio.

\section{Estrutura e organização do grânulo}

A estrutura dos grânulos de amido pode ser pensada em função de 4 escalas ou níveis de organização: molecular (cerca de $1 \AA$ ); estrutura lamelar (9 nm); anéis de crescimento (100 nm) e a morfologia inteira do grânulo ( 1 $\mu \mathrm{m})$ (FRENCH, 1984). Uma representação esquemática de um grânulo de amido mostrando estes diferentes níveis da organização é mostrada na FIGURA 6. As regiões cristalinas no grânulo do amido consistem de duplas hélices de amilopectina, que são radialmente empacotadas no tipo-A (monoclínico) ou tipo-B (hexagonal) (IMBERTY \& PEREZ, 1989). As lamelas consistem de regiões alternadas de material amorfo e semicristalino cuja periodicidade total é $9 \mathrm{~nm}$ em toda as espécies já examinadas (JENKINS \& DONALD, 1998; DONALD et al., 1997). As distâncias de repetição entre essas zonas alternadas de material semicristalino e amorfo representam o que tem sido chamado de anéis de crescimento. Zonas semicristalinas surgem numa periodicidade de $100 \mathrm{~nm}$, com zonas amorfas onde as moléculas de amilopectina 
estão em um estado menos organizado e na qual a maior parte da amilose está concentrada (DONALD et al., 1997; RIDOUT et al., 2002).



FIGURA 6. Representação esquemática dos níveis de organização do grão de amido e seus biopolímeros. (BULÉON et al., 1998)

Economicamente, o amido é um produto com alto valor agregado e de baixo custo na obtenção. Além de ser facilmente encontrado para realçar a textura e viscosidade em diversos tipos de produtos alimentícios, pode ter aplicação como adesivos e aditivos da indústria papeleira, estabilizadores e modificadores da viscosidade em pinturas e nos líquidos utilizados em perfuração de poços de petróleo (DEFFENBAUGH \& WALKER, 1990; ROACH \& HOSENEY, 1995). Em todos estes casos, explora-se a propriedade relativa à primeira etapa de gelatinização do amido em meio aquoso. Este processo é induzido geralmente por aquecimento. Envolve o rompimento das estruturas conformacionais dos grânulos do amido, liberação dos polissacarídeos que o constituem na solução, causando o inchamento extensivo do polímero. Todo este processo conduz a um aumento na viscosidade da suspensão, provocando a formação de uma pasta. Alguns estudos sugerem que surfactantes são hábeis em afetar o processo de gelatinização e, com isto, as propriedades de inchamento do amido e as características das pastas resultantes (ROACH \& HOSENEY, 1995; ELIASSON, 1985; AZIZI \& RAO, 2005).

Devido a sua relevância em muitas aplicações industriais alimentícias, a maioria das investigações sobre o efeito dos surfactantes no inchamento e nas 
propriedades adesivas do amido envolveu o uso dos emulsificantes de grau alimentar, como por exemplo, monoglicerídeos de cadeia longa $\left(\mathrm{C}_{14}-\mathrm{C}_{18}\right)$ e os ésteres de glicose (KROG, 1973; NIERLE \& EL BAYA, 1990; DEFFENBAUGH \& WALKER, 1990; ROACH \& HOSENEY, 1995; ELIASSON, 1985; AZIZI \& RAO, 2005; RICHARDSON et al., 2003). Entretanto, em uma tentativa de aprofundar estes estudos sobre os mecanismos de interação atuantes no processo de gelatinização, surfactantes não-alimentares (SDS, CTAB, monoesterato de glicerila) também foram usados em sistemas-modelo (ELIASSON, 1985; EVANS, 1986; BILIADERIS \& TONOGAI, 1991). Contudo, apesar do número cada vez mais crescente de artigos publicados a respeito da utilização de biopolímeros em associação cooperativa com surfactantes, não se encontraram trabalhos que investigassem a influência da estrutura química do surfactante sobre as propriedades de amidos. Isto se deve à dificuldade em comparar resultados devido: i) a natureza do processo de inchamento ser constituído por múltiplos estágios de equílibrio, ii) a suscetibilidade dos amidos oriundos de distintas fontes botânicas e iii) o uso dos emulsificantes alimentícios, que são geralmente misturas de compostos químicos com diferentes pesos moleculares. Estas complicações têm retardado a compreensão dos mecanismos da interação envolvendo surfactantes e amido.

\subsection{SURFACTANTES E SUAS INTERAÇÕES COM OS COMPONENTES DO AMIDO}

Os agentes ativos de superfície, (tensoativos ou surfactantes) são compostos capazes de alterar as propriedades superficiais e interfaciais de um líquido (SCHICK, 1967; JUNGERMANN, 1970; LINFIELD 1976). São adequados para uma ampla gama de aplicações industriais envolvendo: detergência, emulsificação, lubrificação, capacidade espumante, capacidade umectante, solubilização e dispersão de fases (SCHICK, 1967; JUNGERMANN, 1970; LINFIELD, 1976; ATTWOOD \& FLORENCE, 1983; ZAGO NETO \& DEL PINO, 2006).

Suas moléculas contêm um segmento lipossolúvel (chamado de cauda e solúvel em óleo) e outro hidrossolúvel (cabeça de grupo, solúvel em água). A 
Capítulo 1

solubilidade parcial tanto em água quanto no ambiente apolar permite ao surfactante ocupar a interface de duas substâncias imiscíveis.

Os surfactantes podem ser classificados pela carga iônica da cabeça da molécula. Nos surfactantes aniônicos, a carga molecular é negativa; nos catiônicos, positiva; nos não-iônicos, não há carga e nos anfóteros existem cargas positivas e negativas na mesma molécula (ZAGO NETO \& DEL PINO, 2006).

\subsubsection{AGENTES ANIÔNICOS}

Os tensoativos aniônicos geralmente contêm um dos quatro grupos polares carboxilato, sulfonato, sulfato ou fosfato - combinados com uma cadeia de hidrocarbonetos hidrofóbica. Se esta cadeia é muito curta, são solúveis em água, senão têm baixa solubilidade em água e atuam em sistemas não-aquosos como óleos lubrificantes (ATTWOOD \& FLORENCE, 1983). Dentro desta classificação, encontram-se os compostos como o sulfonato de alquilbenzeno linear, os sulfatos de alquila derivados principalmente do petróleo e com ampla utilização na indústria de sabões e detergentes.

\subsubsection{AGENTES CATIÔNICOS}

Os surfactantes catiônicos comumente utilizados em detergentes, agentes limpadores líquidos de lava-louça e cosméticos estão os compostos contendo um ou vários grupos terciários ou quaternários de amônio. Os sais de amônio terciário com cadeia longa obtidos por neutralização de aminas com ácidos orgânicos ou inorgânicos, raramente são utilizados em detergentes e produtos de limpeza. A sua principal aplicação é no tratamento de têxteis e como amaciantes para roupas (ZAGO NETO \& DEL PINO, 2006).

Os sais de amônio quaternário com um único grupo alquil (C12 - C18), ou dois mais curtos (C8 - C10) são utilizados como substâncias antimicrobianas. Devido à sua capacidade de adsorção em fibras ou fios de cabelo, podem servir também como condicionadores para cabelos (ZAGO NETO \& DEL PINO, 2006). 


\subsubsection{AGENTES NÃO-IÔNICOS}

Ao contrário de seus pares iônicos, os surfactantes não-iônicos não se dissociam em íons hidratados quando em meio aquoso. As propriedades hidrofílicas são promovidas pela hidratação dos grupos amido, amino, éter ou hidroxila. Quando existe um número suficiente destes grupos, a solubilidade aquosa é comparável com a dos surfactantes iônicos. As aplicações são várias e dependem da quantidade de grupos polares presentes, que determinam a solubilidade tanto em água quanto em ambientes apolares (quantificada na prática mediante o índice HLB, ou balanço hidrofílico-lipofílico) (ATTWOOD \& FLORENCE, 1983). Em geral, os surfatantes nãoiônicos são melhores para quebrar interações entre lipídios e entre lipídios e proteínas, que entre proteínas. Por isso, eles são considerados surfactantes nãodesnaturantes e são amplamente usados no isolamento de proteínas de membranas em suas formas biologicamente ativas (BHAIRI, 2001).

Como exemplos da aplicação dos surfactantes não-iônicos derivados de alcoóis lineares (éteres alquil polioxietilenos) pode-se destacar: extração de proteínas de membrana (ADAMO et. al., 2000; ESMANN \& SKOU, 1984; CHO et al., 2000; LE MAIRE, CHAMPEIL \& MOLLER, 2000; VICTORIA \& MAHAN, 1981), separação de outros componentes químicos (BERTHOD et al., 2001; CLOTHIER \& TOMELLINI, 1996) coadjuvante para liberação controlada de droga (YAMAMOTO et al., 1989).

Muitos detergentes não iônicos derivados do polioxietileno têm importância econômica mundial, dadas as suas propriedades de solubilização, que permitem que sejam usados na fabricação de produtos industriais, na área de farmácia, cosméticos, química, etc. Éteres nonilfenóis polioxietilênico como os detergentes da série Renex são usados como agentes espermicidas em preservativos (GALEMBECK, ALONSO \& MEIRELES, 1998). Estes pesquisadores mostraram que Renex de cabeças polares muito longas não são hemolíticos, embora interajam com as membranas de eritrócitos, tornando-as mais fluidas (GALEMBECK, ALONSO \& MEIRELES, 1998). 


\subsubsection{A DISPERSÃO DOS TENSOATIVOS EM ÁGUA.}

De acordo com sua estrutura, composição do meio ou da concentração do tensoativo, este pode se agregar formando micelas, vesículas ou cristais líquidos liotrópicos, além de outros agregados (FIGURA 7). Em casos particulares, a agregação em meio orgânico apolar e de baixa constante dielétrica pode formar as micelas reversas (ATTWOOD \& FLORENCE, 1983; HIEMENZ \& RAJAGOPALAN, 1986).

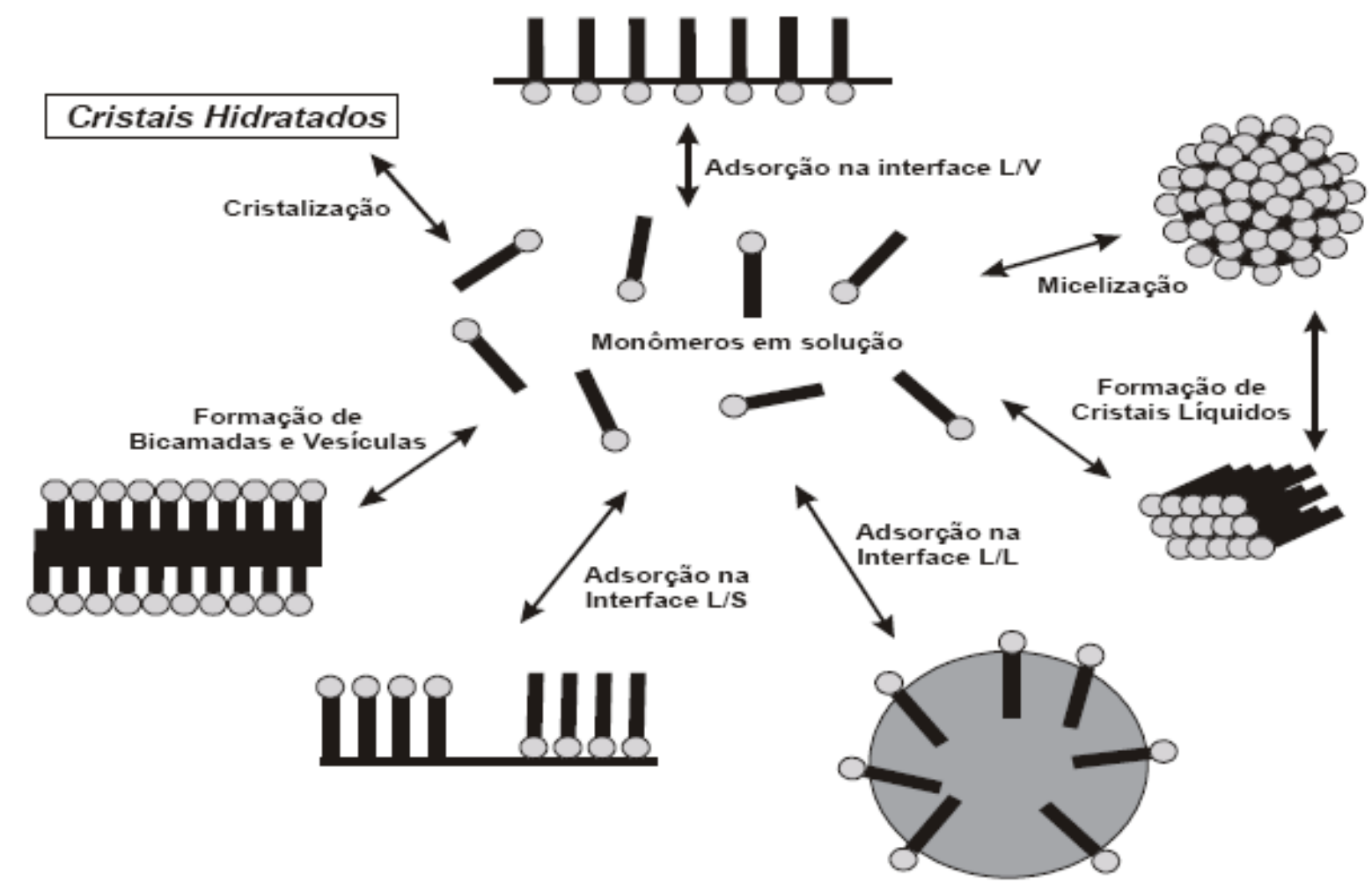

FIGURA 7. Modos de organização das moléculas de tensoativo para a diminuição das energias interfacial e superficial. ( $L=$ líquido, $V=$ vapor, $S=$ sólido) (MYERS, 1999).

Quando em água, sua dissolução provoca o surgimento de interações em geral desfavoráveis entre a parte apolar do surfactante e o meio aquoso. Os principais fatores que ocasionam tal comportamento, seriam a elevada tensão superficial águacadeia hidrocarbônica, redução do grau de liberdade das cadeias hidrocarbônicas e ordenamento das moléculas de água ao redor da cadeia hidrofóbica (MOROI, 1992; TANFORD, 1961). A dissolução de tensoativos não-iônicos em água é descrita como cadeias poliméricas dissolvidas em água. Estas cadeias poliméricas podem ser 
Capítulo 1

imaginadas como pequenas molas que repelem gotas, interrompendo sua "coalescência”, conhecido como estabilização estérica (HARTLEY, 1939; GRUEN, 1985).

Diversos parâmetros físico-químicos servem para caracterizar estes compostos, tais como: a concentração micelar crítica $(\mathbf{c m c})$, concentração mínima necessária de monômeros para constituição de uma micela; o número de agregação, $\mathbf{N}_{\mathrm{ag}}$, (número médio de monômeros presentes nos agregados), o raio hidrodinâmico, $\mathbf{R}_{\mathbf{h}}$, (raio da micela), o grau de dissociação micelar, $\boldsymbol{\alpha}$, entre muitos outros. Todos estes parâmetros sofrem interferência das condições experimentais, tais como: temperatura, pressão, presença de aditivos associadas à natureza do tensoativo etc. (LINDMAN \& ZANA, 1980; FENDLER, 1982; LINDMAN, 1984).

\subsubsection{AMIDO E SUAS INTERAÇÕES COM SURFACTANTES}

A A habilidade de interação entre surfactantes com amido e amido gelatinizado foi reportada por alguns pesquisadores (GHIASI, VARRIANO-MARSTON \& HOSENEY, 1982; ELIASSON, 1985; ELIASSON, 1986; EVANS \& HAISMAN, 1982; ELIASSON, 1994; SVENSSON, AUTIO \& ELIASSON, 1998). Contudo, durante este trabalho, analisando a literatura até o momento, notamos que pouco tem sido realizado em relação à capacidade de interação entre surfactante e os diversos tipos de amido existentes. Os estudos mais representativos referem-se particularmente aos componentes do amido, estudados separadamente.

\subsubsection{COMPLEXOS AMILOSE-SURFACTANTES}

A associação entre agentes tensoativos e amilose sugere o envolvimento de complexos moleculares formados com a conformação helicoidal simples do biopolímero. A literatura descreve forte evidência para este modelo com base em estudos de difração de raios-X dos complexos cristalinos em estado sólido (MIKUS, HIXON \& RUNDLE, 1946; FRENCH, PULLEY \& WHELAN, 1963; TAKEO, TOKUMURA \& KUGE, 1973; GODET et al., 1995) e algumas suposições 
complementares de estudos estruturais em solução aquosa (BULPIN, WELSH \& MORRIS, 1982; BULPIN, CUTLER \& LIPS 1987). Buléon e colaboradores publicaram em 1998 um estudo teórico sobre a associação entre ácidos graxos e amilose. Neste estudo, resultados de modelagem molecular evidenciam a inclusão da parte hidrofóbica do ácido graxo dentro da parte hidrofóbica da cavidade helicoidal da amilose.

Vale ressaltar que a cavidade helicoidal da amilose, a qual tem um caráter hidrofóbico, possui cerca de 0,5 nm de diâmetro (BULÉON et al.. 1998), dimensão que satisfaz os requisitos necessários para a solvatação e complexação de diversos surfactantes. Esta cavidade possui ainda característica similar àquela apresentada pelas ciclodextrinas, com o diferencial em relação à sua flexibilidade em tamanho e comprimento em relação aos sítios de ligação. Outro ponto interessante apontado pelos estudos de modelagem diz respeito à situação energeticamente favorável tanto para o surfactante quanto para a amilose, o que resulta em complexos dificilmente dissociáveis.

Estudos de complexos cristalinos da amilose e uma variedade de moléculas orgânicas, indicam que cada volta completa da hélice contém de 6,7 ou 8 resíduos de glicose [59-63], sendo este número dependente do tamanho e da forma da molécula (TAKEO, TOKUMURA \& KUGE, 1973; JANE, 1984). Os estudos de modelagem molecular sugerem que a parte apolar dos ácidos graxos existe em uma média de duas a três voltas para cada complexo formado, enquanto que as cabeças polares não são facilmente incluídas pela cavidade da hélice em virtude das repulsões eletrostáticas e estéricas (GODET et al., 1993).

Já estudos calorimétricos indicam que a estabilidade térmica e a formação dos complexos são dependentes da natureza química do ligante (grau de insaturação, tamanho da cadeia, características da cabeça polar), do grau de polimerização do biopolímero, condições experimentais (temperatura, templo e solvente utilizado) (KOWBLANSKY, 1985; BILIADERIS \& SENEVIRATNE, 1990; RAPHAELIDES \& KARKALAS, 1988; KARKALAS et al., 1995; TUFVESSON, WAHLGREN \& ELIASSON, 2003). 


\subsubsection{COMPLEXOS AMILOPECTINA-SURFACTANTE}

Há alguns registros sobre a formação de complexos entre amilopectina e surfactantes, contudo, em uma quantidade bem inferior aos atribuídos para os complexos com amilose. Alguns estudos em solução (SVENSSON, GUDMUNDSSON \& ELIASSON, 1996; LUNDQVIST, ELIASSON \& OLOFSSON, 2002) e algumas evidências indiretas obtidas por meio de estudos calorimétricos de algumas variedades de amido na presença de surfactantes (BILIADERIS \& TONOGAI, 1991; ELIASSON, FINSTAD \& LJUNGER, 1988; LUNDQVIST, ELIASSON \& OLOFSSON, 2002) reforçam a possibilidade de formação de complexos também com este biopolímero. Estes estudos, entretanto, não permitem analisar a natureza dos complexos, permitindo apenas que se faça referência à sua existência. Além disso, a literatura sugere que a ligação é mais cooperativa (LUNDQVIST, ELIASSON \& OLOFSSON, 2002) e é extremamente sensível a pequenas mudanças na estrutura molecular da amilopectina (LUNDQVIST et al., 2002).

Neste trabalho de Doutoramento, estudou-se a interação cooperativa entre alguns tensoativos não-iônicos e a amilopectina, através de processos fotofísicos. Por este motivo, o tópico a seguir descreve os príncipios básicos envolvidos nas sondas estudadas.

\subsection{PROCESSOS FOTOFÍSICOS}

\subsubsection{PRINCÍPIOS DE FOTOFÍSICA ORGÂNICA}

Moléculas orgânicas podem atuar como sondas fotofísicas que permitem a determinação indireta de várias características físico-químicas do meio de dispersão. Se tomarmos como exemplo um polímero disperso em água, poderemos indiretamente, inferir sobre a polaridade do ambiente em que se encontra a molécula, o tamanho da cavidade que a comporta, a microviscosidade local, dentre outras. 
Capítulo 1

Os fenômenos fotofísicos estão associados ao processo iniciado pela absorção de radiação eletromagnética por uma molécula e seguido por sua relaxação (GILBERT \& BAGGOTT, 1991; LAKOWICZ, 1999). Toda a cinética envolvendo estes processos é adequadamente explicada pelo diagrama de energia de estados eletrônicos moleculares desenvolvido pelo físico Alexander Jablonski (JABLONSKI, 1933).

A forma atual do diagrama de Jablonski representa o estado fundamental $\left(\mathrm{S}_{0}\right)$ de uma molécula e seus estados excitados singletes $\left(S_{n}\right)$ e tripletes $\left(T_{n}\right)$, conforme FIGURA 8. A denominação singlete e triplete se fundamenta pela multiplicidade destes níveis que é dada através da expressão $2 S+1$, sendo $S$ o número quântico de spin eletrônico total. Em um estado singlete a soma dos spins de todos os elétrons da molécula (spin total) é nulo $(S=0)$, enquanto que em um estado triplete encontram-se dois elétrons com os spins paralelos e $S=1$.

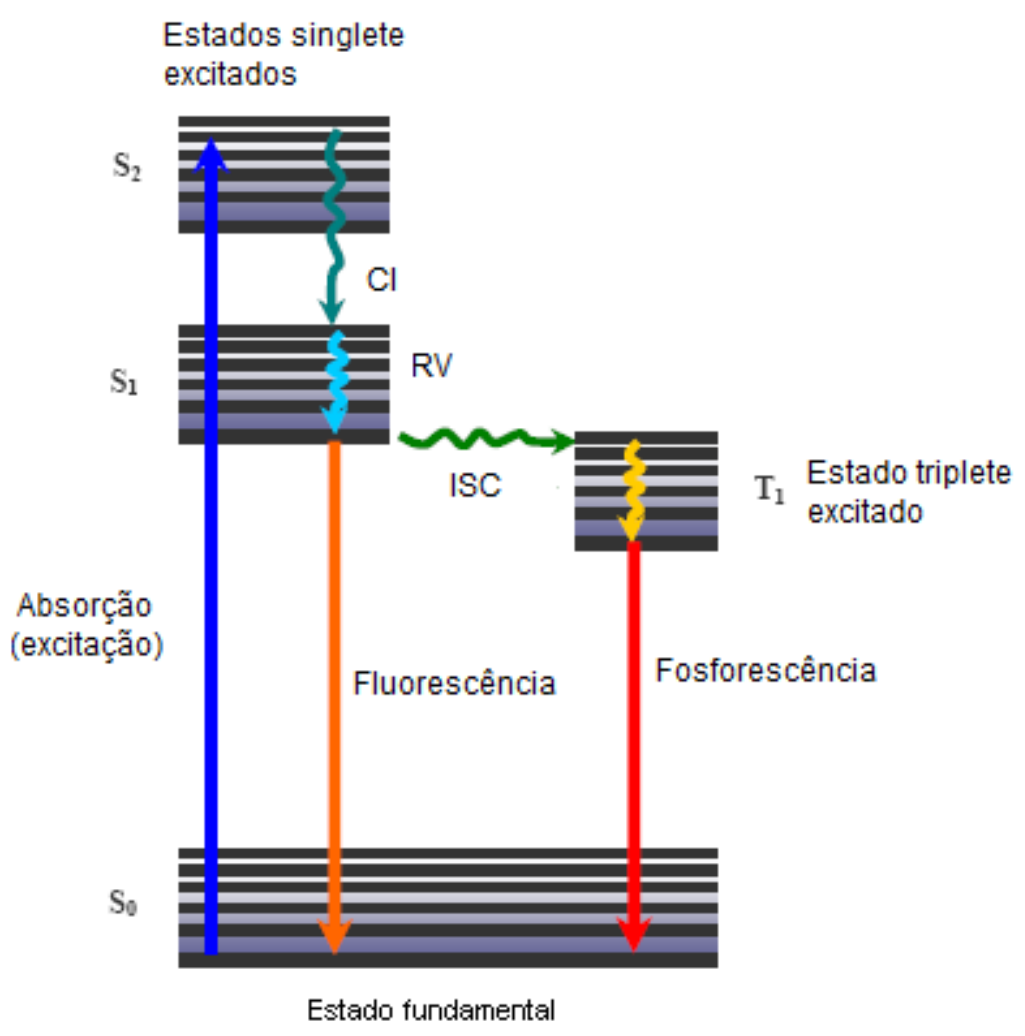

FIGURA 8. Diagrama de Jablonski.

Os níveis de energia eletrônicos moleculares são indicados pelas linhas horizontais (ilustrando a natureza quase instantânea da absorção e emissão de luz) 
separadas verticalmente pela diferença de energia entre eles. Para cada nível eletrônico (n) estão associados níveis vibracionais (menores) (v).

O estado caracterizado pela menor energia eletrônica possível $\left(\mathrm{S}_{0}\right)$ é denominado estado fundamental e à temperatura ambiente o nível mais povoado desse estado é de nível vibracional $v=0$. Se a energia do fóton incidente é muito pequena para excitar o elétron até um de seus níveis superiores, a espécie permanece no estado fundamental ou o fóton é espalhado.

Já quando o fóton possui energia suficiente para excitar um elétron do estado fundamental (So) para um nível energético superior $S_{n}$, ocorre uma transição óptica (absorção de energia) entre esses estados. Cada um desses níveis eletrônicos possui vários níveis vibracionais para os quais as transições ópticas podem ocorrer. Os estados excitados mais energéticos têm um tempo vida muito curto e os elétrons nesses níveis rapidamente relaxam para o nível vibracional mais baixo do $\mathrm{S}_{1}$.

A perda de energia entre dois estados eletrônicos pode ser representada por processos não-radiativos ou radiativos. Os não-radiativos que ocorrem entre estados eletrônicos de mesmo spin, $S_{n} \rightarrow S_{m}$ ou $T_{n} \rightarrow T_{m}(n>m)$, são chamados de conversão interna (IC) e são caracterizados pela taxa $k_{i c}$. Aqueles que ocorrem entre os estados do spin diferente $S_{n} \rightarrow T_{m}$ são denominados de cruzamento entre sistemas (ISC) e são caracterizados pela $k_{i s c}$. Em geral, $k_{i c} \gg k_{i s c}$, uma vez que as transições entre estados de diferentes multiplicidades são proibidas, em virtude da regra de seleção de spin. Ambos os processos não radiativos são representados pelas setas onduladas. Os radiativos consistem na relaxação por emissão de luz e são denominados de fluorescência $\left(S_{1} \rightarrow S_{0}\right)$ e fosforescência $\left(T_{1} \rightarrow S_{0}\right)$. Geralmente são caracterizados por $k_{r}$.

Em um estado eletrônico a relaxação parte dos níveis vibracionais de maior $\left(S_{n v}\right.$ ou $\left.T_{n v}\right)$ finalizando no nível da energia menor possível $\left(S_{n 0}\right.$ ou $\left.T_{n 0}\right)$. Este processo é denominado de relaxação vibracional e está representado na FIGURA 8 como RV. Em casos específicos a relaxação da molécula pode ser obtida ainda por meio de reações químicas envolvendo as espécies excitadas, tanto nos estados singlete quanto tripletes. 
Capítulo 1

Em termos cinéticos, pode-se imaginar a situação onde a concentração de moléculas eletronicamente excitadas, $\left[\mathrm{M}^{\star}\right]$, decai a zero em função do tempo devido à emissão radiativa espontânea:

$$
M^{*} \rightarrow M+h v^{\prime}
$$

onde: hv' é uma energia menor à absorvida pela molécula. Como conseqüência, a cinética do decaimento será de primeira ordem:

$$
-\frac{d}{d t}[M *]=k_{r}^{0}[M *]
$$

resultando em,

$$
[M *]=[M *]_{0} e^{-k_{r}^{0} t}
$$

Entretanto, se considerarmos o processo radiativo de fluorescência em competição com os demais processos, a velocidade para o decaimento de [ $\left.\mathrm{M}^{*}\right]$ é dada por:

$$
-\frac{d}{d t}\left[M^{*}\right]=k_{f}\left[M^{*}\right]+k_{I S C}\left[M^{*}\right]+k_{I C}\left[M^{*}\right]
$$

A concentração de moléculas no estado excitado, [M*], decai exponencialmente para zero, com uma constante de velocidade $k_{\text {exp }}$, dependente de todos os processos que levem à desativação do estado $M^{*}$,

$$
\left[M^{*}\right]=\left[M^{*}\right]_{0} e^{-k_{\exp } t}, \quad k_{\exp }=k_{f}+k_{I S C}+k_{I C}
$$

ou seja, $k_{\exp }=\Sigma k_{i}$. Logo, a medida do tempo de vida experimental é dada por:

$$
\tau_{\exp }=\frac{1}{k_{\exp }}=\frac{1}{\Sigma k_{i}}
$$

Sob certas circunstâncias, onde fotoprocessos adicionais competem efetivamente com a fluorescência, a medida do tempo de vida será menor quando

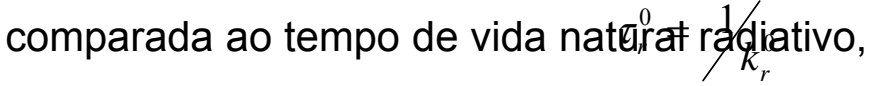

(GILBERT \& BAGGOTT, 1991).

Assim, o tempo de vida também pode ser considerado o tempo médio que uma molécula permanece no estado excitado e pode ser medido através de técnicas resolvidas no tempo. 
Capítulo 1

No caso da fluorescência, o tempo $\tau_{S 1}$ pode ser medido por meio do decaimento da intensidade da fluorescência da molécula em função do tempo, comumente denominado "tempo de vida da fluorescência" $\left(\tau_{\mathrm{fl}}\right)$, geralmente com valores na ordem de nanosegundos. Nos processos radiativos envolvendo os estados triplete, o tempo de vida é da ordem de microsegundos. A análise da absorção óptica dos estados excitados de intermediários reativos produzidos após a excitação pode ser realizada por meio de técnicas como a fotólise por pulso de laser, que resumidamente, emprega dois pulsos de luz defasados por um intervalo de tempo. Outra possibilidade é utilizar técnicas que empregam feixes de laser de altas intensidades (como a varredura-Z). Em outras palavras, em um campo eletromagnético intenso, podem surgir efeitos de índice de refração não linear, absorção multifotônica, absorção pelos estados excitados, espalhamento não linear, (BOYD, 1992; SHEN, 1984) dentre outros.

\subsubsection{COMPOSTOS SOLVATOCRÔMICOS}

Quando o espectro de absorção de uma molécula é obtido em meios com diferentes polaridades, a posição, a intensidade e a largura da banda podem se alterar na região do ultravioleta e visível (UV/Vis) (LEROSEN \& REID, 1952; PAINELLI \& TERENZIANI, 1999; LAKOWICZ, 1999). Este fenômeno foi chamado de solvatocromismo por Hantzsch em 1922 (REICHARDT, 1988; SUPPAN \& GHONEIM, 1997). Isto é devido às interações físicas intermoleculares solutosolvente (tais como: íon-dipolo, dipolo-dipolo, dipolo-dipolo induzido, ligação de hidrogênio, dentre outras), que tendem a modificar a diferença de energia entre os estados fundamental e excitado (LAKOWICZ, 1999) dos cromóforos presentes na molécula. Um deslocamento hipsocrômico (para a região do azul), observado com o aumento da polaridade do solvente, é usualmente chamado de solvatocromismo negativo. O deslocamento batocrômico (para a região do vermelho) é chamado de solvatocromismo positivo (LAKOWICZ, 1999).

Muitas avaliações quantitativas do efeito do solvente nas transições eletrônicas têm usado corantes zwitteriônicos, que possuem grupos doadores de elétrons ligados por sistemas conjugados a grupos receptores de elétrons. A transição 
eletrônica dos mesmos é associada a uma transferência de carga entre estes dois grupos, produzindo um estado excitado com um momento de dipolo diferente do estado fundamental eletrônico. Se o estado fundamental é mais dipolar do que o excitado, a banda de absorção sofre uma mudança hipsocrômica com um aumento da polaridade do solvente, caracterizando um solvatocromismo negativo. Já a mudança batocrômica com o aumento da polaridade do solvente é característica de compostos que exibem solvatocromismo positivo (BUCKINGHAM et al., 1978).

Vários pesquisadores tentaram desenvolver escalas para quantificar o efeito observado de solvatocromismo relacionado com as propriedades de polaridade de solventes (Von LIPPERT, 1957; MATAGA, KAIFU \& KOIZUMI, 1956 e KOSOWER, 1958). Neste trabalho, foi utilizado o corante de Reichardt, cujas características estão descritas a seguir.

\subsubsection{Estudo do Deslocamento Espectral de sondas fotofísicas.}

Dentre as escalas polaridade baseadas nas propriedades de cromóforos, destaca-se a escala $\mathrm{E}_{\mathrm{T}}(30)$ de Reichardt, baseada no solvatocromismo negativo do corante 2,6-difenil-4-(2,4,6)-trifenilpiridíniofenolato (REICHARDT, 1988).



FIGURA 9. Estrutura do corante de Reichardt, utilizado como padrão de polaridade.

Este corante foi escolhido por Dimroth e Reichardt em 1963 (REICHARDT, 1988) para desenvolver uma escala de polaridade de solventes, baseada na variação do seu comprimento de onda de absorção máxima ( $\lambda$ máx). O corante de Reichardt exibe um pronunciado solvatocromismo negativo, devido às ligações de hidrogênio com o solvente (REICHARDT, 1994; CATALÁN et al., 1995). A banda de absorção é deslocada hipsocromicamente $(\Delta \lambda$ máx $=357 \mathrm{~nm})$ quando se troca 0 solvente de éter difenílico $\left(\lambda_{\text {máx }}=810 \mathrm{~nm}\right)$ para água $(\lambda \operatorname{máx}=453 \mathrm{~nm})$. A solução 
deste corante é vermelha em metanol, violeta em etanol, azul em álcool isoamílico, verde em acetona e verde-amarelada em acetato de etila, englobando toda a região visível e permitindo uma estimativa visual da polaridade do meio (REICHARDY \& HARBUSCH-GORNET,1983). De acordo com tais informações, foi elaborada a escala conhecida como $\mathrm{E}_{\mathrm{T}}(30)$, que se refere à energia de transição da betaína $\mathrm{n}^{\circ}$ 30 (REICHARDT, 1994).

A estabilização desta betaína no solvente ocorre devido a mudança de um estado fundamental bastante polarizado para um estado excitado mais apolar, tendo como características principais: (1) exibe um momento dipolar permanente forte, adequado para registrar interações dipolo-dipolo induzido e dipolo-dipolo; (2) possui um sistema $\pi$-elétron polarizado, adequado para registrar 8 interações de dispersão e (3) o átomo de oxigênio fenóxido exibe um forte centro básico doador de par de elétrons, sendo adequado para interações com ácidos de Brönsted (ligações de hidrogênio) e ácidos de Lewis (receptores de par de elétrons). A carga positiva do corante de Reichardt é deslocalizada e estericamente alterada. Desta forma, a absorção de transferência de carga intramolecular desse corante depende da força de solvatação eletrofílica dos solventes (REICHARDT, 1994; KAMLET, ABBOUD \& TAFT, 1981).

Os valores de $\mathrm{E}_{\mathrm{T}}(30)$ são estimados a partir da equação,

$$
E_{T}(30)=28591 / \lambda_{\text {máx }}(n m)
$$

onde $\lambda_{\text {máx }}$ representa o valor do comprimento de onda do máximo de absorção da banda de transferência de carga do corante.

Devido às recomendações do $\mathrm{SI}$, os valores de $\mathrm{E}_{\mathrm{T}}(30)$ têm sido reportados em uma escala adimensional, através da normalização dos resultados, usando-se água e tetrametilsilano (TMS) como solventes nos limites extremos da escala,

$$
E_{T}^{N}=\frac{E_{T}(\text { solvente })-E_{T}(T M S)}{E_{T}(\text { água })-E_{T}(T M S)}=\frac{E_{T}(\text { solvente })-30,7}{32,4}
$$

A grande limitação da escala decorre da insolubilidade do corante de Reichardt em solventes apolares, como hidrocarbonetos alifáticos. A saída obtida foi obter, a partir do corante, um derivado mais lipofílico, como aquele representado na FIGURA 
Capítulo 1

10. Este derivado permitiu obter os valores das energias de transição nos solventes, onde o corante de Reichardt não era solúvel (KAMLET, ABBOUD \& TAFT, 1981).

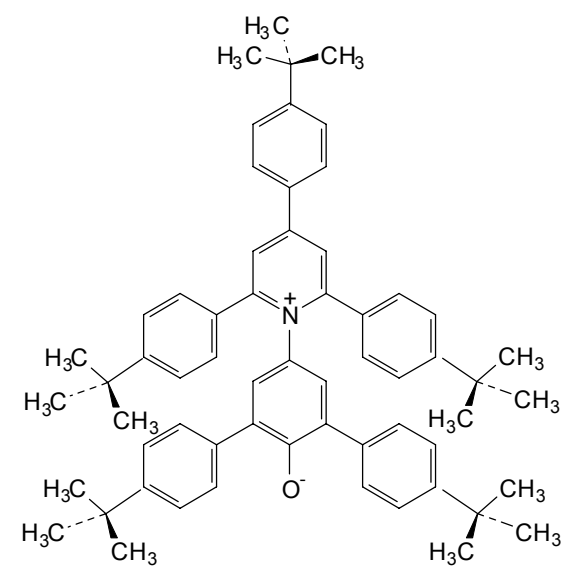

FIGURA 10. Derivado do corante de Reichardt utilizado para estudos em solventes de baixa polaridade.

\subsubsection{Efeitos do Solvente no Espectro de Emissão.}

A polaridade do solvente também provoca grandes efeitos na emissão de fluoróforos polares (LAKOWICZ, 1999; BUNCEL \& RAJAGOPAL, 1990; GILBERT \& BAGGOTT, 1991; REZENDE, 1997). Esses efeitos são mais bem exemplificados com as propriedades fotofísicas do pireno.

O espectro de fluorescência do pireno foi relatado pela primeira vez por Nakajima (1971) e, posteriormente, usado por Kalyanasundaram e Thomas (1977) e por Dong e Winnik (1982) para a introdução de um parâmetro empírico de polaridade do solvente, a chamada escala Py. O espectro apresenta cinco bandas vibrônicas principais bem resolvidas entre 370 e $400 \mathrm{~nm}$, (a banda $0 \rightarrow 0$ é chamada de 1 e assim por diante). A banda vibrônica 3 , correspondente à transição $S_{1}(v=0) \rightarrow S_{0}$ $(v=2)(0,2)$, traduz uma transição fortemente permitida por simetria sendo a sua intensidade insensível à variação da polaridade do meio. Porém, as bandas restantes correspondem a transições electrônicas proibidas, evidenciando alterações da sua intensidade de emissão com a polaridade do meio, sendo o pico $\mathrm{I}_{1}$ (correspondente à transição $\left.S_{1}(v=0) \rightarrow S_{0}(v=0)(0,0)\right)$ o que apresenta uma variação mais acentuada. Assim, a razão das intensidades de emissão das bandas vibrônicas 1 e 3 servem como uma medida quantitativa da polaridade do solvente $(P y=1 / 3)$ embora ela seja difícil de ser determinada com exatidão. O mecanismo 
exato de como os solventes polares aumentam a intensidade das transições vibrônicas proibidas por simetria por meio de uma redução na simetria local ainda hoje não é completamente compreendido. Para se ter uma idéia da sensibilidade desta escala, em dioxano a razão $1 / 3>1$ enquanto que em n-heptano $1 / 3<1$.

Uma segunda característica do pireno é a formação de um excímero (contração de 'excited dimer' que origina 'excimer'). A existência e formação do excímero do pireno em solução foi primeiramente observada por Förster e Kasper (1955) que observaram a existência de uma banda adicional no espectro de emissão de fluorescência, para além da emissão usual do monômero do pireno. Muitos hidrocarbonetos aromáticos podem formar excímeros (ex.: naftaleno, pireno). A banda de fluorescência correspondente ao excímero está localizada a maiores comprimentos de onda em comparação com a do monômero, são alargadas e não apresentam estrutura vibracional.

O excímero é o produto resultante do encontro entre uma molécula de pireno no estado singlete excitado e uma molécula de pireno no estado fundamental a uma distância de contato de aproximadamente 3,5 A (FIGURA 11) (TURRO, 1991):

$$
{ }^{1} \mathrm{Py}^{*}+{ }^{1} \mathrm{Py} \rightarrow{ }^{1}\left[\mathrm{PyP} \mathrm{]}{ }^{*}\right.
$$

Onde [PyPy] $]^{\star}$ representa que a energia de excitação está delocalizada entre as duas moléculas.
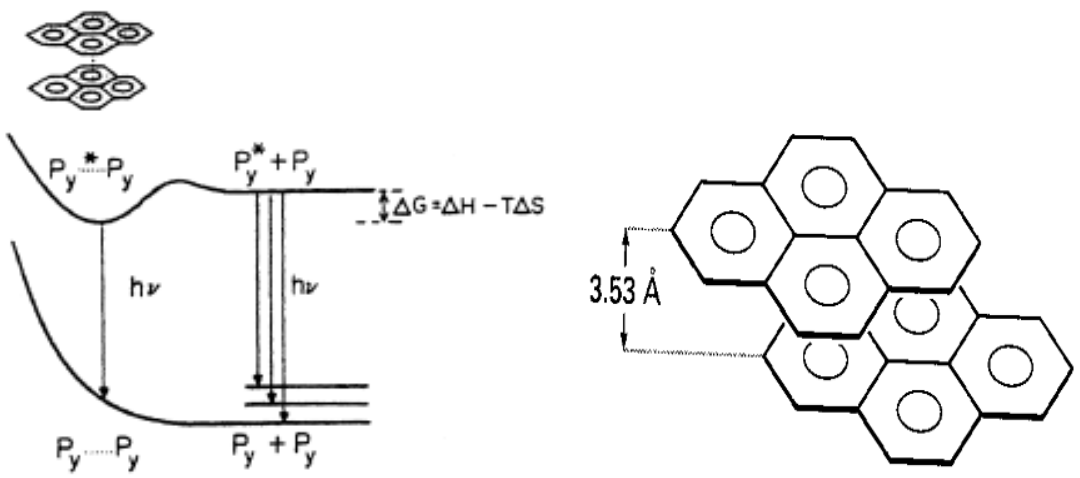

FIGURA 11. Esquema representativo para a formação do exímero do pireno.

Esta nova espécie emite em comprimentos de onda superiores (aproximadamente $480 \mathrm{~nm}$ ) ao do monômero do pireno (370 nm) (FIGURA 12). Na formação do excímero, as duas moléculas têm de adotar uma geometria face-a-face 
Capítulo 1

(também designada conformação em sanduíche), que permite uma maior sobreposição dos orbitais $\pi$ estabilizando o complexo formado



FIGURA 12. Espectro de emissão de fluorescência do pireno. (TURRO, 1991)

A importância dos excímeros, na caracterização de vários sistemas, deve-se ao fato da sua formação estar dependente das características do meio em que se encontra e destas se refletirem na razão da sua intensidade de emissão relativa à do monômero (correntemente conhecida como razão excímero/monômero). A formação de excímero pode efetuar-se intermolecularmente (necessitando-se para isso concentrações da ordem de $10^{-2}-10^{-3} \mathrm{M}$ ) ou intramolecularmente, (neste caso, a concentração do pireno necessária para originar excímero pode ser muito mais baixa, em torno de $\left.10^{-6}-10^{-7} \mathrm{M}\right)$.

Quando se trabalha com tensoativos ou para avaliar a cooperação entre tensoativos e polímeros, pode-se utilizar tanto a razão entre as bandas 1/3 quanto excímero/monômero em função da concentração do surfactante para estimar a cmc ou cac do sistema (SILVERIO \& OKANO, 2004). 


\subsection{CÁTION FLAVÍLIO: UMA ESPÉCIE DE INTERESSE}

Antocianinas são importantes indicadores de qualidade em alimentos e quimiotaxonômicos, além serem capazes de aumentar a capacidade de defesa vegetal contra insetos (CLIFFORD, 2000). Evidências sugerem que este grupo fitoquímico pode exibir ação antioxidante-antiradical, antimicrobiana, antiinflamatória, inibição na agregação de plaquetas, prevenção do colesterol, tratamento da retinopatia diabética (CLIFFORD, 2000; ESPIN et al., 2000; MAZZA \& MINIATI, 1993; WANG, CAO \& PRIOR, 1997; KONG et al., 2003).

Fazem parte do grupo dos flavonóides, compostos fenólicos caracterizados pelo núcleo básico flavílio (cátion 2-fenilbenzopirílio) que consiste de dois anéis aromáticos unidos por uma unidade de três carbonos e condensada por um oxigênio. A antocianina é constituída por duas ou três porções, uma aglicona (antocianidina), um grupo de açúcares e, freqüentemente, um grupo de ácidos orgânicos. Existem cerca de 400 antocianinas diferentes (KONG et al., 2003), encontradas em numerosas famílias de plantas (JACKMAN \& SMITH, 1996), contribuindo para a cor de flores e frutas e atuando como filtro das radiações UV nas folhas. Em certas plantas estão associadas com a resistência aos patógenos (MAZZA \& MINIATI, 1993). A identificação em extratos brutos por meio dos espectros de UV-Visível é complexa, pois há sobreposição das bandas de absorção das espécies presentes (WANG, CAO \& PRIOR, 1997).

A reatividade química das antocianinas é bastante complexa, pois a estabilidade da sua cor é fortemente dependente do $\mathrm{pH}$. Em geral, as antocianinas são mais estáveis em soluções ácidas do que em neutras e alcalinas. Em soluções aquosas, as antocianinas podem existir sob a forma de pelo menos cinco diferentes estruturas acopladas entre si via reações de equilíbrio dependentes do $\mathrm{pH}$, conforme mostrado na FIGURA 13 (MARKAKIS, 1982). 


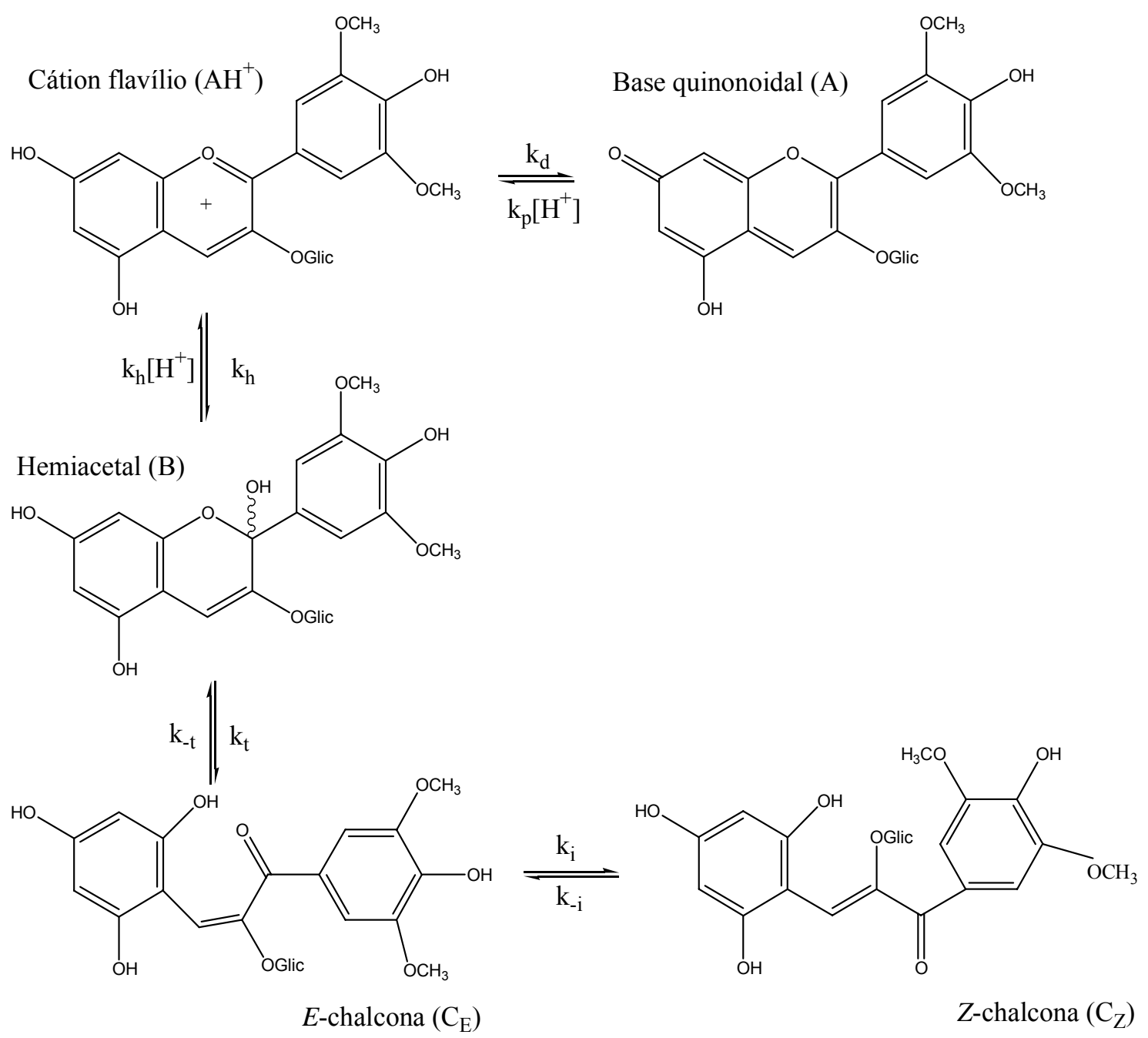

FIGURA 13. Representação das equações envolvidas para a oenina, uma antocianina natural (MARKAKIS, 1992).

Em soluções com pH abaixo de três, a estrutura predominante é o íon flavílio $\left(\mathrm{AH}^{+}\right)$que é um aceptor de elétrons. Isto torna esta estrutura um agente pró-oxidante com um potencial de redução muito maior do que suas formas neutras. Em soluções de $\mathrm{pH}$ fisiológico, onde as propriedades antioxidantes se manifestam, a estrutura predominante é tipicamente o hemiacetal $(B)$ em equilíbrio com pequenas quantidades das chalconas isoméricas $\left(\mathrm{C}_{E}\right.$ e $\left.\mathrm{C}_{Z}\right)$. Um exemplo deste esquema de reações é a oenina, uma antocianina de ocorrência natural, encontrada nas cascas de uvas. A perda do próton do cátion flavílio (vermelho), que prevalece em soluções aquosa de $\mathrm{pH}$ 2, produz a base quinonoidal (A) de cor azul. Por outro lado, em soluções com pH acima de quatro, a hidratação do cátion flavílio forma os dois hemiacetais diastereoisômeros (B) que são incolores, os quais podem subseqüentemente abrir para a E-chalcona $\left(C_{E}\right)$ e a Z-chalcona $\left(C_{Z}\right)(M A R K A K I S, 1982)$. 
Na natureza, as antocianinas tipicamente contêm um ou mais resíduos de açúcar (o primeiro resíduo de açúcar encontra-se ligado sempre na posição três, podendo ser glicose, ramnose, galactose, xilose ou arabinose). Na planta, na flor ou na fruta, a cor persiste mesmo em valores de $\mathrm{pH}$ mais elevados que em solução aquosa, inclusive na faixa de $\mathrm{pH}$ neutro. Esta persistência da cor in natura deve-se provavelmente a complexação da forma colorida da antocianina (o íon flavílio) com uma molécula incolor (o co-pigmento), que inibe a reação de hidratação em pH ácidos. Este fenômeno, conhecido como "co-pigmentação", também provoca, em alguns casos, profundas mudanças na cor da antocianina, alterando-a, por exemplo, de vermelho para azul (PAULO et al., 2006; FREITAS et al., 2006; RODRIGUES et al., 2006).

Várias estratégias têm sido propostas na literatura para promover a estabilização ou a manipulação das cores das antocianinas em $\mathrm{pH}$ elevado. Entre essas, incluem-se: (a) a auto-associação dos cátions flavílios coloridos; (b) a copigmentação intermolecular envolvendo a associação entre a forma colorida e uma molécula apropriada incolor (co-pigmento); (c) a co-pigmentação intramolecular como ocorre em antocianinas que possuem um grupo cinamato ou uma flavona ligada covalentemente a um dos resíduos de açúcar da antocianina e (d) incorporação das antocianinas em agregados micelares, em ciclodextrinas e em polieletrólitos (PAULO et al., 2006; FREITAS et al., 2006; RODRIGUES et al., 2006). Muitas dessas estratégias de estabilização das cores das antocianinas baseiam-se na formação de complexos moleculares capazes de inibir ou impedir o ataque nucleofílico da água sobre o cátion flavílio, provocando uma diminuição da constante de equilíbrio do processo de hidratação, $\left(K_{h}\right)$, que é o fator que controla a perda de cor. No presente trabalho, focamos nosso estudo no cátion 2-fenilbenzopirílio (FIGURA 14). A ausência de grupos substituintes em sua estrutura permite melhor visualização das reações de hidratação do cátion.

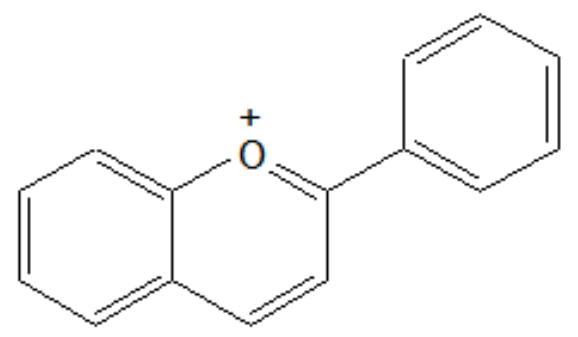

FIGURA 14. Estrutura do cátion 2-fenilbenzopirilio. 
Capítulo 2

\section{CAPÍTULO 2}

\section{OBJETIVOS}

O objetivo desta Tese de Doutorado foi o estudo dos agregados (clusters) da amilopectina na presença e ausência dos tensoativos não-iônicos éteres dodecil (7 e 23)-polioxietilênico (Unitol L-70 e L-230) e nonilfenol (9,5)-polioxietilênico (Renex 95), por meio das propriedades físico-químicas de sondas de polaridade: pireno, xantona e Reichardt.

Os estudos foram realizados através de técnicas espectroscópicas em estado estacionário (absorção de luz UV/visível e fluorescência) e resolvidas no tempo (fluorescência baseada na contagem de fótons únicos e fotólise por pulso de laser). Determinaram-se os valores de: concentração de agregação crítica (cac), concentração micelar crítica $(\mathrm{cmc})$, número de agregação $\left(\mathrm{N}_{\mathrm{ag}}\right)$ e polaridade (escala py e $\mathrm{E}_{\uparrow} 30$ ) para os sistemas avaliados.

Os dados obtidos foram comparados com as soluções contendo a presença ou não dos tensoativos não-iônicos e a carboximetil celulose $(\mathrm{CMC})$ e 2-hidroxietil amido (2-HEAM). Por fim, a estabilidade do cátion 2-fenilbenzopirílio foi avaliada em diferentes solventes orgânicos, nas micelas dos tensoativos estudados, nos biopolímeros e nos complexos biopolímero-tensoativo 
Capítulo 3

\section{CAPÍTULO 3}

\subsection{MATERIAIS E MÉTODOS}

\subsubsection{BIOPOLÍMEROS:}

Amilose (Lote: 103K3785) e amilopectina (Lote: 30K3798) foram adquiridas da Sigma. Da Aldrich, foram utilizados dois tipos de carboximetil celulose. A primeira com viscosidade ultrabaixa $10-55 \mathrm{cPs}, 4 \%$ solubilizada em água, a $25{ }^{\circ} \mathrm{C}$ e a segunda com MM de 90.000 e grau de substituição de 0,7. Foi utilizado, também, o 2-hidroxietilamido (Lote: 16709MQ) da Aldrich.

\subsubsection{TENSOATIVOS:}

Os detergentes não-iônicos éteres dodecil (7 e 23)-polioxietilênico (Unitol L-70 e L-230) nonilfenol (9,5)-polioxietilênico (Renex 95) foram amostras gentilmente cedidas pela Oxiteno. Cloreto de cetilpiridínio monohidratado (CPCI) (96-101\%) da Acros Organics. Todos os tensoativos foram utilizados sem purificação prévia. 
Capítulo 3
$\mathrm{CH}_{3}\left(\mathrm{CH}_{2}\right)_{10} \mathrm{CH}_{2} \mathrm{O}\left(\mathrm{CH}_{2} \mathrm{CH}_{2} \mathrm{O}\right) \mathrm{nH}$
A. $n=7$ Unitol L-70
B. $n=23$ Unitol L-230
$\mathrm{CH}_{3}\left(\mathrm{CH}_{2}\right)_{7} \mathrm{CH}_{2}$
$\mathrm{O}\left(\mathrm{CH}_{2} \mathrm{CH}_{2} \mathrm{O}\right)_{9-10} \mathrm{H}$
C. Renex 95

FIGURA 15. Estruturas dos tensoativos utilizados.

\subsubsection{SONDAS FOTOFÍSICAS:}

Pireno (99 \%), xantona (97\%) foram comprados da Aldrich. Corante de Reichardt Dye da Acros Organics. Cátion flavílio gentilmente sintetizado e cedido pelo Prof. Dr. Paulo Marcos Donate - DQ - FFCLRP/USP.

\subsubsection{SOLVENTES E REAGENTES DIVERSOS:}

Foram ainda utilizados os seguintes soventes e reagentes sem purificação prévida: água destilada ultrapura do sistema Millipore Milli-Q; acetato de etila, acetonitrila, butanol, ciclo-hexano, $n$-hexano, etanol, éter etílico, etileno glicol, metanol, propanol, tetrahidrofurano, tolueno (grau espectroscópico ou PA) da J.T. Baker ou Mallinckrodt. Hidróxido de sódio da Mallinckrodt, tetraborato de sódio monohidratado (99,5 \%), fosfato de sódio dibásico da Merck, ácido clorídrico, citrato de sódio dihidratado (99\%) da Aldrich, tetraborato de sódio monohidratado (98\%) da Mallinckrodt.

\subsection{EQUIPAMENTOS:}

Espectros de absorção de luz UV-visível foram obtidos por meio de um espectrofotômetro HITACHI U-3000 de duplo feixe, empregando-se cubetas de $1 \mathrm{~cm}$ de caminho óptico.

Os experimentos de fluorescência foram realizados em um espectrofluorímetro Hitachi F-4500 acoplado a um banho termostático. Todos os espectros de emissão 
corrigidos foram feitos com soluções na presença de oxigênio a $25^{\circ} \mathrm{C}$, usando uma cubeta de $1 \mathrm{~cm}$ de caminho óptico.

Os tempos de vida de fluorescência, baseados no método de Contagem de Fótons Únicos (SPC, single photon counting) foram obtidos por meio de dois equipamentos:

(1): fluorímetro resolvido no tempo do laboratório do Prof. Dr. Amando Siuiti Ito - DFM - FFCLRP - USP, utilizando como fonte de excitação um sistema laser titânio-safira da Tsunami 3950 Spectra Physics, excitado pelo laser de estado sólido Millenia Spectra Physics. A velocidade de repetição de pulsos foi 5 ps, em conjunto com uma freqüência de $8,0 \mathrm{MHz}$ usando o coletor de pulsos Spectra Physics 3980. O laser foi ajustado na freqüência em 315 nm e o cristal BBO (GWN-23PL Spectra Physics) gerou o seu terceiro harmônico. Pulsos de excitação em 335 nm foram direcionados para o espectrofotômetro Edinburgh FL900. O comprimento de onda de emissão foi selecionado por um monocromador na faixa de 370 a $550 \mathrm{~nm}$. A fotomultiplicadora Hamamatsu R3809U do tipo placa de microondas refrigerada detectou os fótons emitidos. O programa da Edinburgh Instruments foi usado para analisar as curvas de decaimento cinético de fluorescência. $\mathrm{O}$ ajuste adequado de um decaimento multiexponencial foi considerado pela inspeção da representação gráfica do resíduo e pelos parâmetros estatísticos como a redução do chi-quadrado $\left(\chi^{2}\right)$

(2) O fluorímetro resolvido no tempo utilizou como fonte de excitação um laser de Ti-Safira (Spectra-Physics Tsunami) excitado por um laser Millenia X (SpectraPhysics). A velocidade de repetição dos pulsos na saída do laser Ti-Safira foi de 82 $\mathrm{MHz}$. A freqüência de luz da saída deste laser Ti-Safira $(900 \mathrm{~nm})$ foi ajustada por um cristal BBO gerador de terceiro harmônico. Os pulsos de luz foram monitorados com um fotodiodo rápido e usados como sinais para parar a contagem no conversor de tempo para amplitude (Time-to-Amplitude Converter, TAC), sinais de STOP. A emissão de fluorescência foi coletada em ângulo de $90^{\circ}$, depois que passou através de um polarizador ajustado no ângulo mágico (54,7 - prisma polarizador de laser da Spindler \& Hoyer Glan) e de um monocromador (Jobin-Yvon H20 Vis). Os fótons foram detectados com uma fotomultiplicadora de placas de microcanais (Hamamatsu R3809u-50, MCPT, microchannel plate photomultiplier). Os sinais da MCPT deram o início no TAC aos sinais de START. O sistema eletrônico de detecção consistiu em 
um módulo de cartão de contagem SPC-630, da Becker-Hickl. Os discriminadores de fração constantes (Constant Fraction Discriminators, CFD), o conversor de tempo para amplitude (TAC), o conversor de analógico para digital (Analog-to-Digital Converter, ADC) e o analisador de multicanais (Multichannel Analyser, MCA) são integrados ao circuito eletrônico (GIESTA et al., 2003). A resposta do instrumento foi de 19 ps.

Medidas automáticas do perfil do pulso de excitação e emissão de amostras foram feitas até valores de $6 \times 10^{3}$ contagens fossem coletadas no máximo de emissão coletando-se simultaneamente dois comprimentos de onda para uma mesma amostra. Decaimentos de fluorescência foram deconvoluídos do pulso de excitação utilizando-se o programa Sand, que permite a análise global e individual dos decaimentos com otimizações de deslocamentos individuais de máximos (STRIKER et al., 1999). Este equipamento foi gentilmente cedido para utilização pelo Prof. Dr. Antonio Luis Maçanita do Instituto Superior Técnico da Universidade Técnica de Lisboa.

Utilizou-se, também, o equipamento de fotólise por pulso de laser da Applied Photophysics, modelo LKS.60. O laser Brilliant Compact Q-Switched Nd : YAG da Quantel, ajustado em 355 nm, com potência variável de 65 a 100 mJ e duração de pulso de 4 ns, foi utilizado como fonte de excitação das soluções de biopolímeros. Estas soluções foram colocadas em cubetas de quartzo com comprimento óptico de $1 \mathrm{~cm}$, de colo longo. As soluções foram degaseadas com nitrogênio espectroscópico (cerca de 99,9\% de pureza) durante 20 minutos, no mínimo, antes da realização das medidas experimentais. As amostras foram trocadas frequentemente devido à possível degradação das mesmas pela ação incidente do laser. A fonte de monitoramento dos intermediários reativos foi uma fonte pulsada do arco da lâmpada de Xe de 150 W (03-102 Arclamp pulser).

Os espectros e decaimentos cinéticos dos intermediários reativos formados pela ação do laser sobre as amostras foram coletados e analisados inicialmente pelo programa Spectra Kinetic Analyser System Software (versão 4.74, de novembro de 2006), da Applied Photophysics Limited. Cada espectro e decaimento tiveram a potência do laser ajustada ao redor de 45 a $60 \mathrm{~mJ}$ para evitar a ocorrência do aniquilamento T-T da xantona. As medidas experimentais para determinados comprimentos de onda e escala de tempo são o resultado da média de oito disparos 
Capítulo 3

consecutivos do laser sobre a amostra. Este equipamento foi gentilmente cedido pelo Prof. Dr. João Carlos de Lima da Universidade Nova de Lisboa.

\subsection{PROCEDIMENTOS}

\subsubsection{PURIFICAÇÃO DAS SONDAS SOLVATOFLUORESCENTES}

A xantona utilizada foi previamente recristalizada utilizando-se etanol como solvente. O excesso do solvente foi removido por meio de filtração a vácuo. Os cristais foram mantidos em um dessecador acoplado a uma trompa de vácuo até a completa secagem (cristais com ponto de fusão na faixa de $\left.172-174^{\circ} \mathrm{C}\right)^{1}$.

O pireno foi recristalizado três vezes do metanol. Os cristais apresentaram ponto de fusão dentro da faixa especificada na literatura $\left(149-151^{\circ} \mathrm{C}\right)^{2}$.

\subsubsection{PREPARO DAS SOLUÇÕES}

\section{Pireno}

Uma solução-estoque $1 \mathrm{mmol} / \mathrm{L}$ de pireno foi preparada em etanol $95 \%$. Alíquotas desta solução estoque foram utilizadas para obter uma solução aquosa de pireno da ordem de $1 \mu \mathrm{mol} / \mathrm{L}$.

\section{Soluções aquosas de detergentes não-iônicos na presença de pireno}

Soluções-estoque aquosas dos tensoativos não-iônicos (Unitol L-70 e L-230 e Renex 95) a $40 \mathrm{mmol} / \mathrm{L}$ foram preparadas utilizando-se etanol 95\% como cosolvente, mantendo seu volume em $1 \%$ e completando-se o volume final com solução aquosa de pireno $1 \mu \mathrm{mol} / \mathrm{L}$.

\footnotetext{
${ }^{1}$ Valor na literatura: $174{ }^{\circ} \mathrm{C}($ BOLZ \& TUVE, 1973)

${ }^{2}$ Valor na literatura: $151{ }^{\circ} \mathrm{C}$ (BOLZ \& TUVE, 1973)
} 


\section{Soluções aquosa do corante Reichardt}

O corante de Reichardt $10 \mu \mathrm{mol} / \mathrm{L}$ foi preparado em tampão borato $(\mathrm{pH}=9,0)$ (REICHARDT, 1992).

\section{Soluções aquosas de biopolímero na presença de pireno}

Foram adotados dois procedimentos para o preparo das soluções de aquosas de amilopectina $(0,2-1,0 \% \mathrm{~m} / \mathrm{m})$ totalmente límpidas e homogêneas. No primeiro, o pireno foi adicionado após a completa solubilização da amilopectina em água. No segundo, uma solução aquosa de pireno na concentração de $1 \mu \mathrm{mol} / \mathrm{L}$, serviu como solvente para solubilizar a amilopectina. Assim, após a pesagem da massa apropriada de amilopectina adicionou-se o solvente (água quente ou solução aquosa de pireno) e manteve-se o sistema sob agitação e aquecimento a $80-90{ }^{\circ} \mathrm{C}$ durante 30 min (NAGANINE \& KONAE, 1996). Em seguida, a solução foi mantida a $50{ }^{\circ} \mathrm{C}$ por 18 horas. O sistema foi então resfriado lentamente até atingir temperatura ambiente, sem agitação por 6 horas. No caso específico da solução preparada utilizando-se água quente como solvente, a alíquota da solução de pireno foi adicionada neste momento, mantendo-se a solução sob agitação baixa por cerca de $30 \mathrm{~min}$ antes de seu uso. O procedimento experimental adotado para o preparo de soluções de carboximetilcelulose e 2-hidroxietilamido seguiu a adição da solução aquosa de pireno como solvente para solubilizar ambos polímeros. De acordo com cada experimento, adicionaram-se alíquotas das soluções-estoque de tensoativo, permitindo uma variação de 0,1 a $40 \mathrm{mmol} / \mathrm{L}$ na concentração do tensoativo e mantendo-se a concentração de polímero fixa.

\section{Xantona}

Uma solução aquosa saturada de xantona foi preparada pesando-se cerca de 2 $\mathrm{mg}$ de xantona que foi adicionada em $250 \mathrm{~mL}$ de água Milli-Q. Esta solução permaneceu sob agitação e abrigo de luz por, no mínimo, 24 horas. Posteriormente, foi filtrada através de filtros $0,45 \mu \mathrm{m}$ da MilliPore. Esta solução aquosa saturada de xantona foi utilizada como solvente para as soluções de amilopectina e de carboximetil celulose. 
Capítulo 3

\section{Soluções aquosas de biopolímero na presença de xantona}

Após a pesagem da massa necessária de biopolímero (amilopectina ou carboximetil celulose) para fornecer uma concentração da ordem de 0,1 a 3,0 \% $(\mathrm{m} / \mathrm{v})$, foi adicionado o volume necessário para esta concentração em frascos de vidro com tampas. Estes frascos tampados foram aquecidos em banho-maria à $80^{\circ} \mathrm{C}$, por meia hora, sob agitação constante. Após este aquecimento, as soluções foram resfriadas naturalmente, ainda sob agitação até o dia seguinte, para a realização de medidas de fluorescência resolvida no tempo ou de fotólise por pulso de laser.

\section{Cátion flavílio}

Para os estudos de estabilização do cátion flavílio, solubilizou-se o composto diretamente no solvente de interesse e em soluções de amilopectina, carboximetilcelulose, hidroxietilamido, todos a 0,2\% e nos tensoativos não-iônicos a $30 \mathrm{mmol} / \mathrm{L}$, ajustando a absorbância, em seu comprimento de onda máximo, para valores entre 1,0 e 1,8. As soluções, quando possível, foram também tamponadas em tampão citrato/fosfato $(\mathrm{pH} 3,5)$, de modo a favorecer a presença do cátion em solução.

\subsubsection{DETERMINAÇÃO DA CAC E CMC}

A determinação da cac e cmc dos agregados formados por solução de amilopectina e tensoativo não iônico foi feita através da análise das razões das intensidades das bandas de emissão de fluorescência do pireno. Razão 1/3 (considerando $\lambda_{1}=373 \mathrm{~nm}$ e $\lambda_{3}=384 \mathrm{~nm}$ ) e razão excímero/monômero $\left(\lambda_{\mathrm{exc}}=474 \mathrm{e}\right.$ $\left.\lambda_{\text {mon }}=394 \mathrm{~nm}\right)($ SILVERIO \& OKANO, 2004; MIGUEL, 2001).

\subsubsection{PARÂMETRO DE POLARIDADE $\left(E_{T} 30\right)$}

A estimativa de um parâmetro de polaridade $\left(\mathrm{E}_{\mathrm{T}} 30\right)$ do meio foi avaliada pelas mudanças solvatocrômicas no espectro de absorção UV-visível de uma solução 10 
Capítulo 3

$\mu \mathrm{mol} / \mathrm{L}$ do corante de Reichardt em amilopectina $(1 \% \mathrm{~m} / \mathrm{m})$ e nos tensoativos nãoiônicos. Para avaliar a polaridade das soluções com concentrações entre a cac e cmc dos tensoativos utilizaram-se $0,20 \mathrm{mmol} / \mathrm{L}, 0,80 \mathrm{mmol} / \mathrm{L}$ e $1,9 \mathrm{mmol} / \mathrm{L}$ para Renex 95, Unitol L-70 e L-230, respectivamente, além de soluções com concentração de $30 \mathrm{mmol} / \mathrm{L}$ para todos os tensoativos (região acima da $\mathrm{cmc}$ ).

\subsubsection{DETERMINAÇÃO DO NÚMERO DE AGREGAÇÃO (N)}

Os números de agregação foram estimados por meio da supressão de fluorescência em estado estacionário do pireno, utilizando cloreto de cetilpiridínio (CPCI) $(0,10$ a 0,50 mmol/L) como supressor (WINNIK \& REGISMOND, 1996). As intensidades de fluorescência na presença $(F)$ e na ausência $\left(F_{0}\right)$ de $\mathrm{CPCl}$ foram relacionadas com a concentração micelar por meio da relação:

$$
\frac{F}{F_{0}}=\exp -\left(\frac{[C P C l]}{[M]}\right)
$$

onde a concentração micelar, $\mathrm{M}$, é dada pela concentração total de tensoativo não-iônico, S, menos a cac ou cmc, dividido pelo número de agregação:

$$
[M]=\frac{([S]-c m c)}{N}
$$

\subsubsection{ESTABILIDADE DO CÁTION FLAVÍLIO}

A estabilidade do cátion flavílio foi avaliada por meio de medidas espectrofotométricas de absorção de luz UV-visível, monitorando os máximos de emissão em função do tempo, em função de solventes com diferentes polaridades. As medidas foram interrompidas após a redução da intensidade de absorção pela metade (tempo de meia-vida). 
Capítulo 4

\section{CAPÍTULO 4}

\subsection{A ASSOCIAÇÃO COOPERATIVA ENTRE OS SURFACTANTES NÃO IÔNICOS E OS COMPONENTES DO AMIDO AVALIADA POR MEIO DA SONDAGEM COM PIRENO}

Em solução, a estrutura química do biopolímero adota uma conformação dependente de fatores, tais como as interações específicas com o solvente, temperatura e modo de preparo de suas soluções. Esta conformação pode formar microambientes, que fornecerão condições parecidas ou não com aquelas do meio de dispersão.

Determinações diretas (utilizando técnicas que explorem propriedades intrínsecas do biopolímero) ou indiretas (por exemplo, utilização de sondas fotofísicas para estudos de polaridade e de interações específicas) permitem entender o comportamento do biopolímero quando em solução. Neste trabalho, analisamos o comportamento fotofísico do pireno, numa concentração inferior a 1 $\mu \mathrm{mol} / \mathrm{L}$ (WINNIK \& REGISMOND, 1996). Registrou-se que em água, a razão 1/3 (TABELA 2) apresenta valores próximos a 1,9, enquanto que na presença de amilopectina, decresce para valores entre 1,4 e 1,6, dependentes do procedimento de preparo experimental destas soluções (MIRANDA, CACITA \& OKANO, 2007). 
Capítulo 4

TABELA 2. Razão 1/3 do pireno presença de amilopectina a várias concentrações e diferentes procedimentos de preparação da solução de biopolímero, a $25^{\circ} \mathrm{C}$

Amilopectina, \%

Razão 1/3

Sem aquecimento do pireno Com aquecimento do pireno

$\begin{array}{ccc}0 & 1,85 \pm 0,03 & 1,85 \pm 0,09 \\ 0,2 & 1,72 \pm 0,01 & 1,62 \pm 0,03 \\ 0,4 & 1,71 \pm 0,03 & 1,59 \pm 0,01 \\ 0,6 & 1,64 \pm 0,04 & 1,50 \pm 0,02 \\ 0,8 & 1,66 \pm 0,01 & 1,46 \pm 0,02 \\ 1,0 & 1,62 \pm 0,01 & 1,42 \pm 0,01\end{array}$

Esses valores foram tomados como referência para o estudo da associação cooperativa dos surfactantes não-iônicos éteres dodecil (7 e 23)-polioxietilênico (Unitol L-70 e L-230, respectivamente) e nonilfenol (9,5)-polioxietilênico (Renex 95) com amilopectina. A seguir são apresentados os resultados obtidos por meio de análises das intensidades relativas das bandas de emissão de fluorescência do pireno.

A FIGURA 16 mostra gráficos representativos da emissão da fluorescência do pireno $(1 \mu \mathrm{mol} / \mathrm{L})$ em amilopectina $1 \%$ na presença e ausência de diferentes concentrações de Unitol L-70, em função do método de preparação da solução. A FIGURA 16 (I) exibe os espectros obtidos da solução na qual o pireno foi adicionado quando o procedimento de aquecimento já havia sido finalizado. Já a FIGURA 16 (II) demonstra o comportamento espectral do pireno quando aquecido juntamente com a amilopectina. O mesmo comportamento é observado para outros dois surfactantes (Unitol L-70 e Renex 95). 


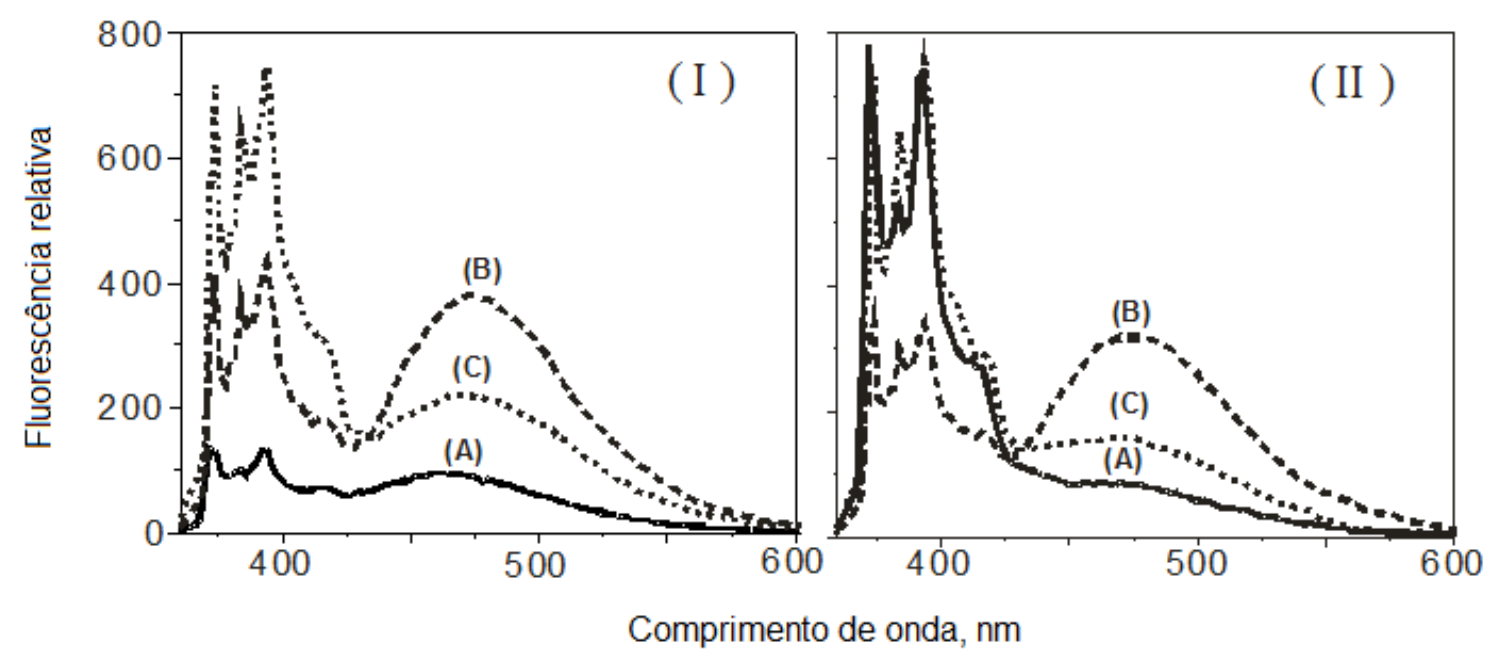

FIGURA 16. Espectro de emissão de fluorescência do pireno em (A) amilopectina $1 \%$, na presença de (B) Unitol L-70 1,0 mmol. $\mathrm{L}^{-1}$, and (C) $2,0 \mathrm{mmol} . \mathrm{L}^{-1}$, a $25^{\circ} \mathrm{C}$. (I) pireno foi adicionado após o resfriamento as solução de amilopectina; (II) pireno e amilopectina foram aquecidos juntos.

Para uma melhor comparação são apresentados na FIGURA 17 os espectros de fluorescência normalizados do pireno em amilopectina $1 \%$, na ausência de tensoativos, totalmente dependentes da condição na qual a sonda foi incorporada na solução do biopolímero.

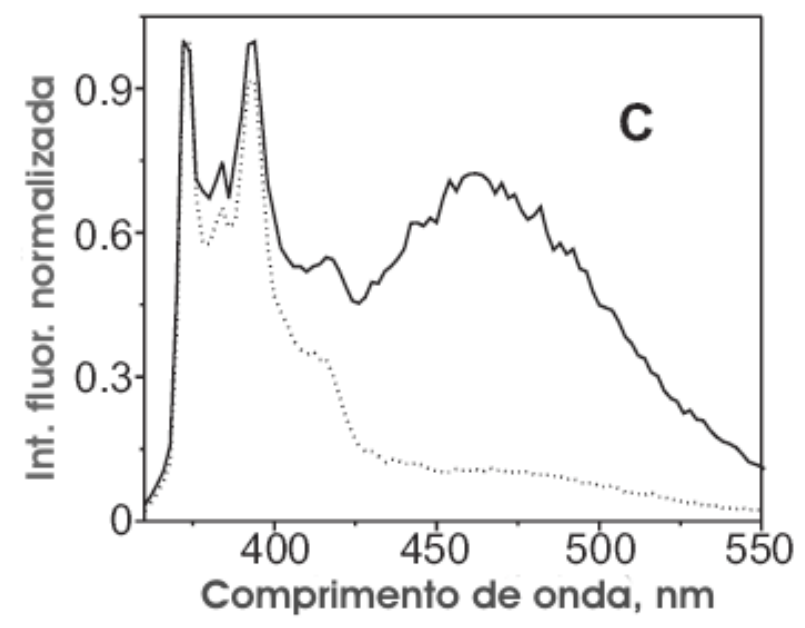

FIGURA 17. Espectro de emissão de fluorescência do pireno em amilopectina 1\%.. (linha contínua) pireno foi adicionado após o resfriamento as solução de amilopectina; (linha tracejada) pireno e amilopectina foram aquecidos juntos.

O aumento na emissão de fluorescência da banda do monômero do pireno (de 374 a $394 \mathrm{~nm}$ ) evidencia que a incorporação da sonda é favorecida onde ela foi aquecida juntamente com a amilopectina. Na literatura, a estrutura da amilopectina 
nos grão de amido é descrita como uma conformação super-hélice (BERTOFT, 2004; WAIGH et al., 2000). O aquecimento de uma solução aquosa dos grãos de amido provoca os seguintes processos: a fusão destas hélices de amilopectina, inchamento do grão provocado pela presença de solvente e aumento da viscosidade em solução. Posteriormente, dando seqüência ao processo de aquecimento, este último em conjunto com a agitação provocam o desordenamento da estrutura do grão, que se solubiliza em solução aquosa e a viscosidade desta solução diminui (JOBLING, 2004; WAIGH et al., 2000). A extensão do conteúdo de água, a presença de solutos adicionados, a taxa de aquecimento, a origem do amido afetam a transição nemática-esméctica que o grão sofre do estado seco para o hidratado (FIGURA 18). Na configuração dupla-hélice das cadeias de amilopectina como descrito por Imberty e Perez (1998), existe também a possibilidade do biopolímero conter um poro central com um diâmetro de cerca de $19 \AA$ (FIGURA 19). O conteúdo de água de cerca de $27 \%$ leva ao ponto de saturação deste poro (DI BARI et al., 2003). Neste trabalho, a temperatura de aquecimento $\left(80-90^{\circ} \mathrm{C}\right)$ usada para o preparo das soluções de amilopectina não atingiu a temperatura empregada para o estudo de retrogradação das amostras (geralmente maiores que $130{ }^{\circ} \mathrm{C}$ ) (LUNDQVIST et al., 2002). Entretanto, a estrutura ramificada da amilopectina atribui características únicas a este polímero. Por exemplo, recentemente a amilopectina foi escolhida como composto modelo para investigações do comportamento de difusão em soluções semidiluídas de polímeros ramificados (YANG et al., 2006). Os resultados dispostos na FIGURA 16 sugerem que o procedimento de aquecimento para solubilização da amilopectina em solução promove a formação de vários clusters poliméricos. Quando a sonda é aquecida juntamente com a amilopectina, os monômeros do pireno localizam-se preferencialmente dentro dos clusters. Quando o pireno é adicionado após o resfriamento da solução, não há difusão em solução o suficiente para levar a sonda ao mesmo microambiente, intensificando a banda de emissão de fluorescência do excímero de pireno. Uma pesquisa realizada sobre a dependência angular do espalhamento de luz dinâmico de frações de amido (GALINSKY \& BURCHARD, 1997) também concluiu que o movimento dos segmentos da amilopectina é afetado pela sua estrutura ramificada. 


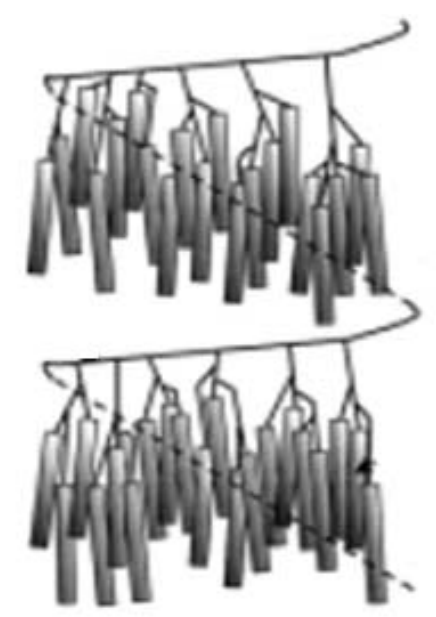

(a)

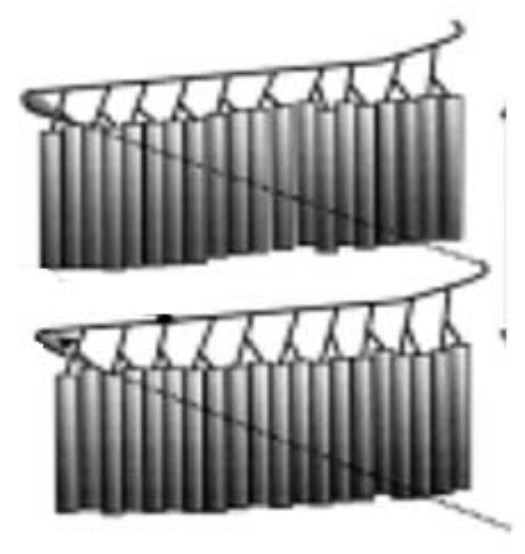

(b)

FIGURA 18. Estrutura seca (nemático) (b) Estrutura esmética hidratada (WAIGH et al., 2000).



FIGURA 19. Esquema ilustrativo das hélices hidratadas (WAIGH et al., 1998).

\subsubsection{A RAZÃO 1/3 DO PIRENO. DETERMINAÇÃO DA CMC E CAC.}

O pireno empregado em baixa concentração (cerca de 1,0 $\mu \mathrm{mol} / \mathrm{L}$ ) em soluções homogêneas mostra-se sensível quanto à intensidade de emissão de fluorescência das bandas 1 e 3 dependendo da polaridade do meio, fornecendo a escala 
Capítulo 4

experimental py de polaridade de solventes (WINNIK \& REGISMOND, 1996). Neste trabalho, a razão 1/3 do pireno nos microambientes de amilopectina é 1,57. Quando as concentrações de surfactante não-iônico aumentam (FIGURA 20A), o valor decresce para $1,2-1,3$, representando a mesma ordem da $\mathrm{cmc}$ do dodecilsulfato de sódio $(1,1)$ e de emulsões de tensoativos polioxietilênicos (1,3) (WINNIK \& REGISMOND, 1996). Na ausência de amilopectina, os surfactantes não-iônicos se auto-agregam para formar micelas normais. Os valores de $\mathrm{cmc}$ dos surfactantes não-iônicos estão dispostos na TABELA 3

TABELA 3. cac, $\mathrm{cmc}$ e $N_{a}$ para os surfactantes não-iônicos na presença de amilopectina a várias concentrações e diferentes procedimentos de preparação da solução de biopolímero, a $25^{\circ} \mathrm{C}$.

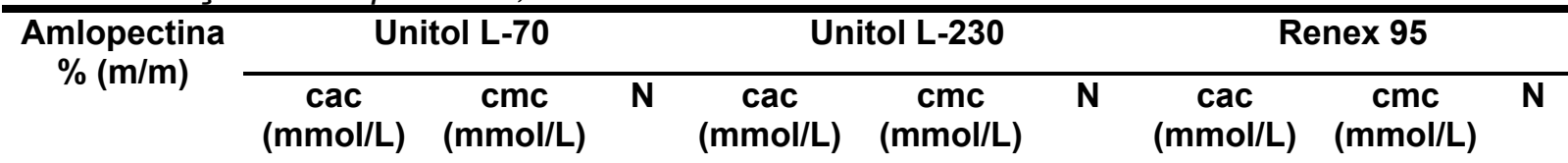

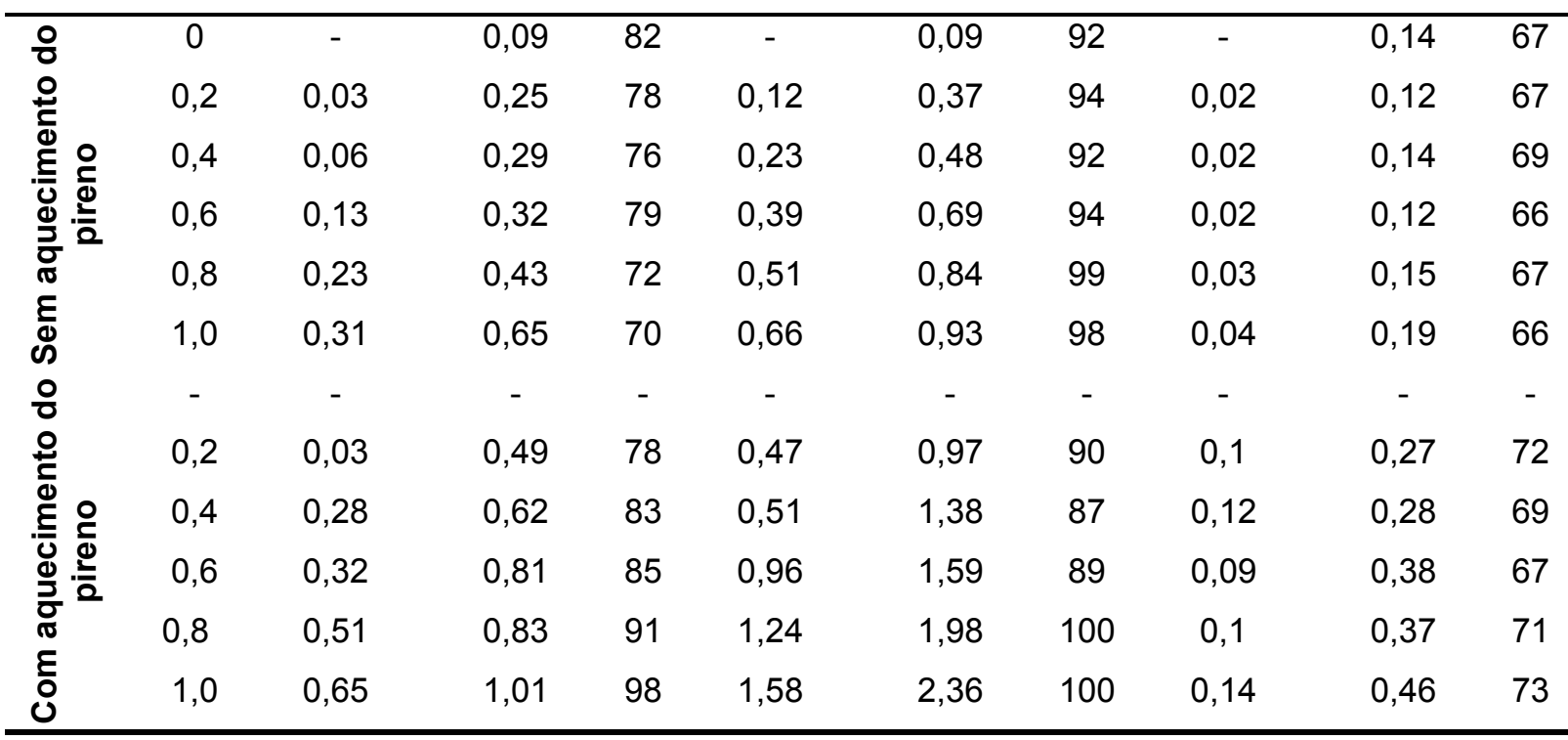

a $N$ foi determinado para soluções de surfactante não-iônico $30 \mathrm{mmol} / \mathrm{L}$ (após a $\mathrm{cmc}$ ) $b \mathrm{cmc}=0,08 \mathrm{mmol} / \mathrm{L}$ (WONG et al.,.1999), 0,07 mmol/L (McINTIRE, 1990), $N=56-84$ (TÓTH \& MADARASZ, 2006).

$c$ éter nonilfenol (5)-polioxietilênico $\mathrm{cmc}=0,47 \mathrm{mmol} / \mathrm{L}$, and $N=72(\mathrm{GHOSH}, \mathrm{KHATUA}$ \& BHATTACHARYA, 2004); éter nonilfenol (9)-polioxietilênico $\mathrm{cmc}=0,072 \mathrm{mmol} / \mathrm{L}$ (DAI \& TAM, 2003) 

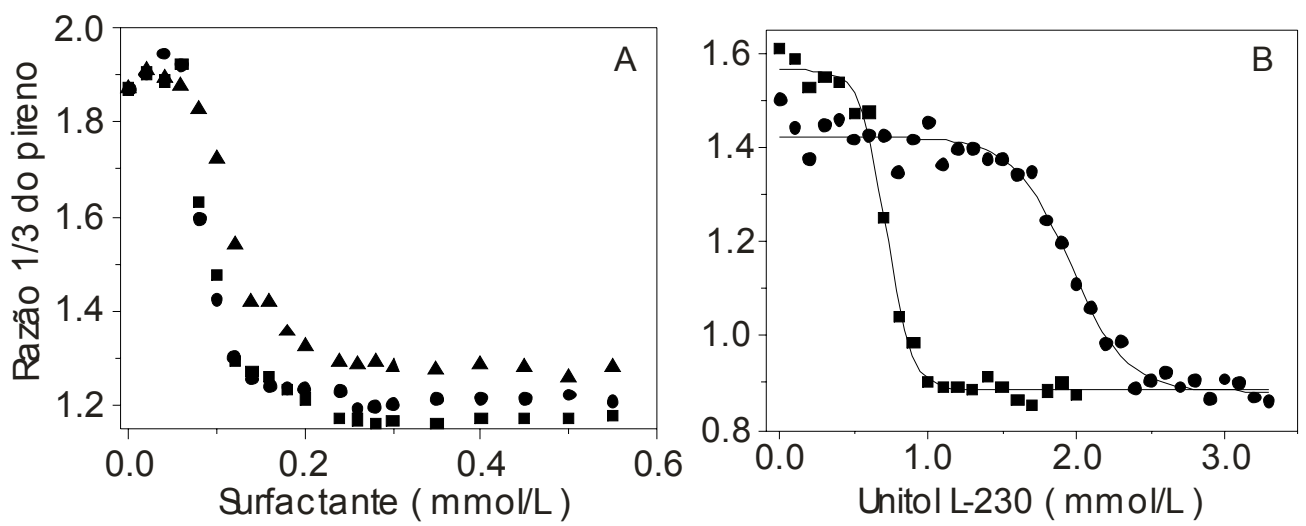

FIGURA 20. Intensidade relativa das bandas $1 / 3$ de emissão do pireno em função de: (A) concentração de surfactante não-iônico ( $\boldsymbol{\bullet}$, Renex 95; •, Unitol L-70, e $\boldsymbol{\Lambda}, L-$ 230); e (B) Unitol L-230 em soluções aquosas de amilopectina ( $\boldsymbol{\bullet}, 0,2 \%$; $, 1,0 \%)$, a $25^{\circ} \mathrm{C}$.

A cmc experimental do Unitol L-230 (0,09 mmol/L) está de acordo com dados já publicados: 0,08 mmol/L (WONG et al., 1999) e 0,07 mmol/L (McINTIRE, 1990). A cmc do Renex 95 (derivado do nonilfenol contendo 9,5 unidades de oxietileno) é $0,14 \mathrm{mmol} / \mathrm{L}$, enquanto que na literatura, a $\mathrm{cmc}$ de $0,47 \mathrm{mmol} / \mathrm{L}$ foi reportada para um derivado contendo 5 unidades de $\mathrm{EO}$ e $0,072 \mathrm{mmol} / \mathrm{L}$ para o derivado contendo 9 EO, ambas estimadas por meio de microcalorimetria (TÓTH \& MADARÁSZ, 2006). A diferença entre esses valores é provavelmente devido ao comprimento da cadeia polioxietilênica e do grau de pureza dos surfactantes.

A FIGURA 20B representa o gráfico da razão $1 / 3$ na presença de amilopectina em função do aumento das concentrações de Unitol L-230. É possível notar a clara indicação de uma associação cooperativa entre a estrutura da amilopectina e os surfactantes não-iônicos (Unitol L-70 e L-230) (SILVÉRIO \& OKANO, 2004; MIGUEL, 2001). Isto deve acontecer da mesma forma como tem sido descrito para surfactantes catiônicos (LUNDQVIST, ELIASSON \& OLOFSSON, 2002a,b) e aniônicos (SVENSSON, GUDMUNDSSON \& ELIASSON, 1996). As ramificações da amilopectina são capazes de formar complexos com vários ligantes, como lipídios, e surfactantes (SVENSSON, GUDMUNDSSON \& ELIASSON, 1996). Concluímos que a formação dos complexos independe da carga do surfactante.

As cac (SILVÉRIO \& OKANO, 2004; MIGUEL, 2001) são muito dependentes do método de preparação das soluções de amilopectina (TABELA 3). Tanto a cmc quanto a cac são diretamente dependentes da concentração do polímero. Em outras palavras, as maiores concentrações de amilopectina promovem um aumento no 
número de ramificações superficiais do biopolímero, que são responsáveis pela formação dos clusters de amilopectina em solução. Eles representam excelentes microambientes para interagir com monômeros de surfactante. Quantidades adicionais desses surfactantes saturam os clusters com monômeros dos tensoativos não-iônicos ou dos complexos polímero/surfactante. A partir deste ponto, ao adicionar maior quantidade de tensoativo, o processo conduz à formação das micelas em meio aquoso.

O tensoativo Renex 95 apresenta resultados distintos. Quando analisadas as soluções onde a sonda foi adicionada após o resfriamento da solução de amilopectina, existia apenas uma cmc média de 0,14 mmol/L. Duas hipóteses podem ser levantadas: (1) o surfactante não interage cooperativamente com a estrutura do biopolímero, provavelmente em virtude da presença do anel aromático em sua estrutura química. A densidade eletrônica produzida grupo aromático não permite a aproximação do monômero até a hidroxila da amilopectina. (2) A interação entre os monômeros de Renex 95 e a estrutura da amilopectina ocorre a uma concentração muito baixa de amilopectina $(<1 \mathrm{mmol} / \mathrm{L})$. Contudo, esta segunda hipótese é a menos provável. Quando a sonda e a amilopectina são aquecidas juntas (TABELA 3), o Renex 95 apresenta uma cac muito baixa e quase constante $(0,11 \mathrm{mmol} / \mathrm{L})$ e a $\mathrm{cmc}$ é diretamente proporcional à concentração de biopolímero. Entretanto, a variação da cmc do Renex é muito baixa, quando comparada aos outros dois surfactantes não-iônicos.

Como a cmc e cac da TABELA 3 foram determinadas a partir das propriedades fotofísicas do pireno, existe uma clara diferença entre os valores, dependendo do método de preparação da solução, o qual é mais evidente em concentrações maiores de amilopectina. O procedimento de aquecimento quando a sonda está presente com o biopolímero leva a microambiente de polaridade (razão 1/3) de 1,57, menor que pireno em água pura, 1,92. Por esta razão, propõem-se que as moléculas de pireno estajam localizadas dentro de clusters da amilopectina, próximos da parte polar da estrutura do esqueleto polimérico. Como o pireno é uma sonda hidrofóbica e não está hidratado, a principal conclusão é que os grupos hidroxila da amilopectina desempenham um papel similar ao da água dentro destes clusters. Quando a concentração de surfactante não iônico aumenta, a solução aquecida com pireno e amilopectina produz um deslocamento no espectro de emissão de fluorescência 
Capítulo 4

para comprimentos de onda maiores com relação àqueles em água. Ao mesmo tempo, a razão 1/3 decresce de 1,6 para 0,8-0,9 após a cmc. Deslocamento similar é observado para pireno solubilizado em meios apolares e muito hidrofóbicos (índice de baixa polaridade de 0,6) (WINNIK \& REGISMOND, 1996). Por causa da presença da estrutura ramificada da amilopectina, a difusão do pireno é menor neste caso, levando a um aumento nos valores de cmc e cac. Os valores de $\mathrm{cmc}$ e cac do Renex são conseqüências da pouca difusão da sonda no sistema.

Por outro lado, após o resfriamento da solução de amilopectina, a sonda demonstra dificuldade para entrar no mesmo microambiente de antes, uma vez que a mobilidade dos segmentos de amilopectina é impedida pelas ramificações (GALINSKY \& BURCHARD, 1997). A razão 1/3 do pireno, sem aquecimento inicia em 1,85 e decresce até 0,85 . Aqui, o pireno é mais sensível à concentração aquosa de surfactante não-iônico, fornecendo valores de cmc e cac menores do que aqueles, onde a sonda foi aquecida juntamente com o biopolímero.

A título de comparação, a associação cooperativa do surfactante não-iônico com 2-hidroxietilamido e carboximetilcelulose foi investigada, preparando soluções nas mesmas condições que as de amilopectina, aquecendo a sonda com 0 biopolímero. Os valores de cac e cmc são apresentados na TABELA 4. 
Capítulo 4

TABELA 4. Cac, $\mathrm{cmc}$ e $N$ para soluções de surfactantes não-iônicos com biopolímeros, a $25^{\circ} \mathrm{C}$.

\begin{tabular}{|c|c|c|c|c|c|c|c|c|c|c|}
\hline \multirow{2}{*}{\multicolumn{2}{|c|}{$\begin{array}{l}\text { Amilopectina } \\
\%(\mathrm{~m} / \mathrm{m})\end{array}$}} & \multicolumn{3}{|c|}{ Unitol L-70 } & \multicolumn{3}{|c|}{ Unitol L-230 } & \multicolumn{3}{|c|}{ Renex 95} \\
\hline & & $\begin{array}{c}\mathrm{cmc} \\
(\mathrm{mmol} / \mathrm{L})\end{array}$ & $\begin{array}{c}\mathrm{cmc} \\
(\mathrm{mmol} / \mathrm{L})\end{array}$ & $\mathbf{N}$ & $\begin{array}{c}\mathrm{cmc} \\
(\mathrm{mmol} / \mathrm{L})\end{array}$ & $\begin{array}{c}\text { cmc } \\
(\mathrm{mmol} / \mathrm{L})\end{array}$ & $\mathbf{N}$ & $\begin{array}{c}\text { cmc } \\
(\mathrm{mmol} / \mathrm{L})\end{array}$ & $\begin{array}{c}\mathrm{cmc} \\
(\mathrm{mmol} / \mathrm{L})\end{array}$ & $\mathbf{N}$ \\
\hline \multirow{5}{*}{ 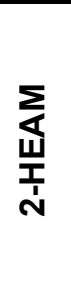 } & 0,2 & 0,11 & 0,41 & 82 & 0,08 & 0,30 & 85 & - & 0,12 & 65 \\
\hline & 0,4 & 0,11 & 0,45 & 84 & 0,09 & 0,32 & 84 & - & 0,23 & 63 \\
\hline & 0,6 & 0,18 & 0,49 & 90 & 0,08 & 0,34 & 86 & - & 0,22 & 65 \\
\hline & 0,8 & 0,25 & 0,60 & 92 & 0,11 & 0,41 & 88 & - & 0,23 & 64 \\
\hline & 1,0 & 0,28 & 0,70 & 92 & 0,15 & 0,37 & 86 & - & 0,23 & 67 \\
\hline \multirow{5}{*}{$\sum_{U}^{U}$} & 0,25 & - & 0,16 & 80 & - & 0,14 & 80 & - & 0,23 & 65 \\
\hline & 0,50 & - & 0,17 & 82 & - & 0,14 & 80 & - & 0,25 & 68 \\
\hline & 1,0 & - & 0,12 & 79 & - & 0,13 & 79 & 0,08 & 0,36 & 65 \\
\hline & 1,5 & - & 0,16 & 81 & - & 0,13 & 81 & 0,08 & 0,40 & 63 \\
\hline & 2,0 & - & 0,19 & 82 & - & 0,14 & 79 & 0,09 & 0,40 & 69 \\
\hline
\end{tabular}

É possível notar um comportamento similar entre os valores obtidos para o 2hidroxietilamido (2-HEAM) e para a amilopectina. Os grupos 2-hidroxietila nas estruturas principais da amilose e amilopectina aumenta a solubilidade do 2hidroxietilamido em água. Entretanto, a intensidade da mudança da razão excímero/monômero é menor do que em amilopectina pura. A conformação do 2hidroxietilamido em solução não deve ser a mesma, afetando as características dos clusters do biopolímero, tais como tamanho, a interpenetração com as ramificações de outros polímeros, assim por diante. Além disso, os grupos 2-hidroxietila afetam a interação dos surfactantes não-iônicos (Unitol L-70 e L-230) com os clusters do biopolímero. Para ambos surfactantes, não há um drástico aumento na cac ou cmc, sendo menores que os complexos amilopectina-surfactante não-iônico. Por outro lado, não há associação cooperativa do 2-hidroxietilamido com Renex 95. Os valores de $\mathrm{cmc}$ do Renex $(0,21 \mathrm{mmol} / \mathrm{L})$ são comparáveis com os determinados com amilopectina sem aquecimento da solução.

A seguir são apresentados os gráficos referentes à associação entre o 2hidroxietilamido (2-HEAM) e os tensoativos. 
Capítulo 4
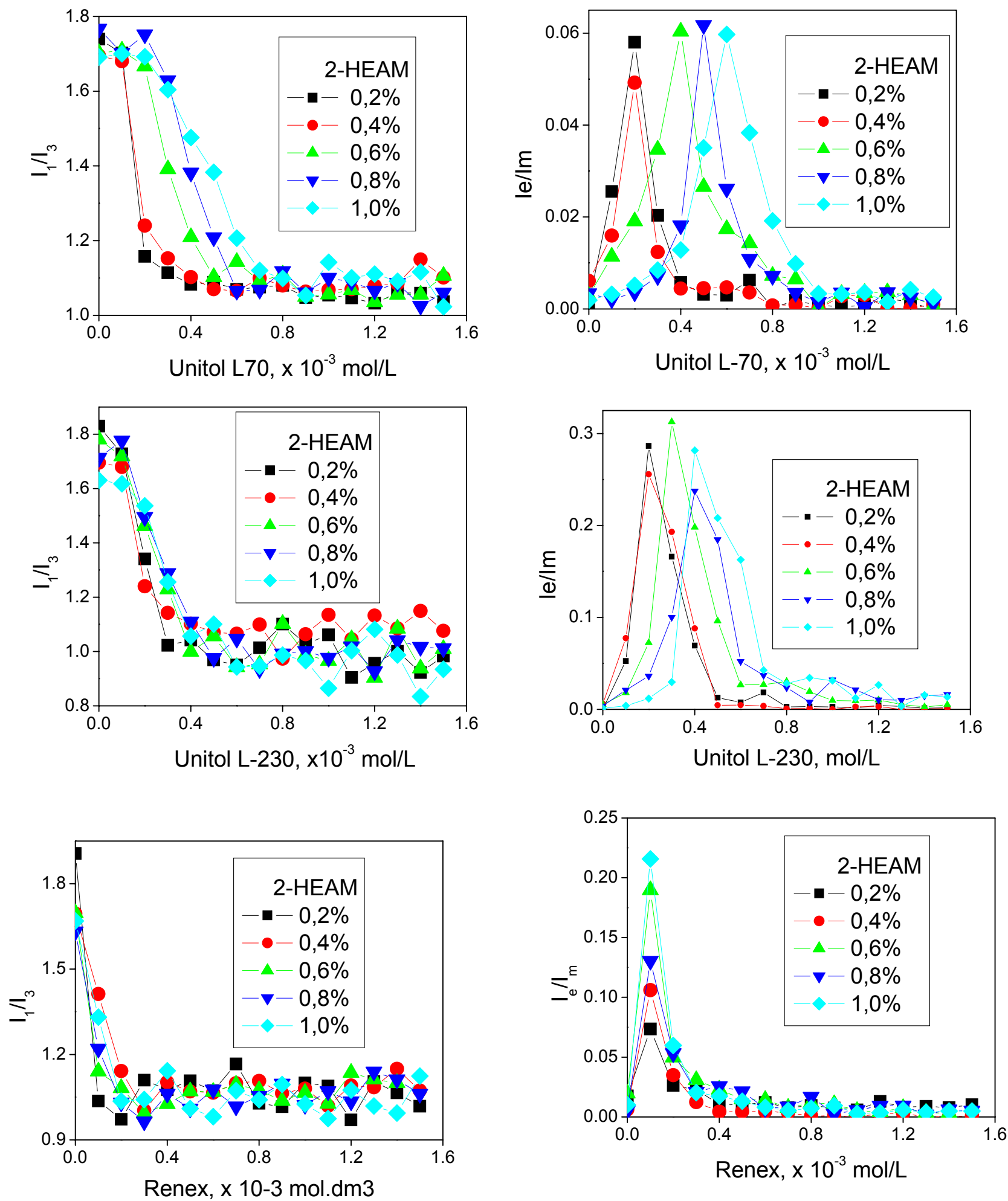

FIGURA 21. Gráficos da razão 1/3 e excimero/monomero do pireno em função de Unitol L-70, Unitol L-230, Renex 95 em soluções com diferentes concentrações de 2hidroxietilamido. Pireno foi adicionado durante o preparo da solução. 
Capítulo 4

Os dados dispostos na TABELA 4 mostram uma clara diferença entre a amilopectina ramificada e a carboximetilcelulose linear. Como verificado em outro trabalho (THURESSON \& LINDMAN,1997), o polímero deve ter sítios suficientemente hidrofóbicos para permitir a associação com surfactantes nãoiônicos. A cmc é pouco maior que a do surfactante puro, e é quase constante. Por outro lado, com o aumento da concentração de carboximetilcelulose, o Renex é capaz de ligar cooperativamente ao polímero devido à sua estrutura química.

Polímeros de celulose, como é o caso da carboximetilcelulose, apresentam uma organização espacial bastante distinta em relação à amilopectina. As interações intermoleculares apresentadas pelas cadeias de celulose seguem o comportamento trivial de camadas sobrepostas (FIGURA 22), proporcionada pela ausência de torção nas ligações das unidades de glicose. Já no caso da amilopectina, as torções levam à formação das hélices e conseqüentemente aos clusters discutidos anteriormente.

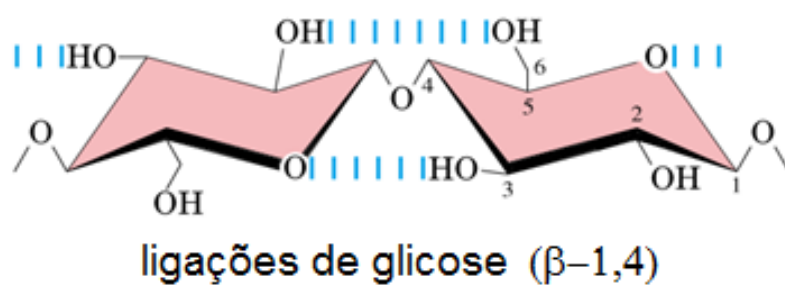

(a)

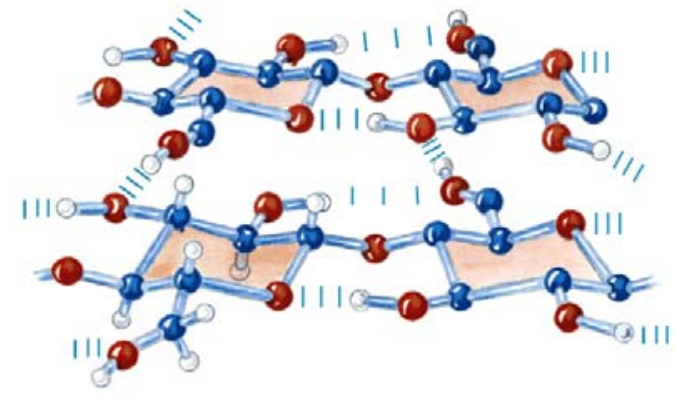

(b)

FIGURA 22. Interações entre as unidades de glicose nos biopolímeros de celulose. (b) conformação em camadas sobrepostas dos derivados de celulose.

Os gráficos abaixo demonstram o comportamento apresentados pela associação entre a CMC e os surfactantes. 
Capítulo 4


FIGURA 23. Gráficos da razão 1/3 e excimero/monomero do pireno em função de (A) Unitol L-230, (B) Unitol L-70, (C) Renex 95 em soluções com diferentes concentrações de carboximetilcelulose. Pireno foi adicionado durante o preparo da solução. 
Capítulo 4

\subsubsection{A RAZÃO EXCÍMERO/MONÔMERO DO PIRENO}

O espectro na FIGURA 16 também permite a análise da razão excímero/monômero para várias concentrações de amilopectina e a interação com surfactantes não-iônicos. Como esperado, a razão excímero/monômero mostrou resultados completamente dependentes do método de preparação empregado para a solução amilopectina/pireno (FIGURA 24).
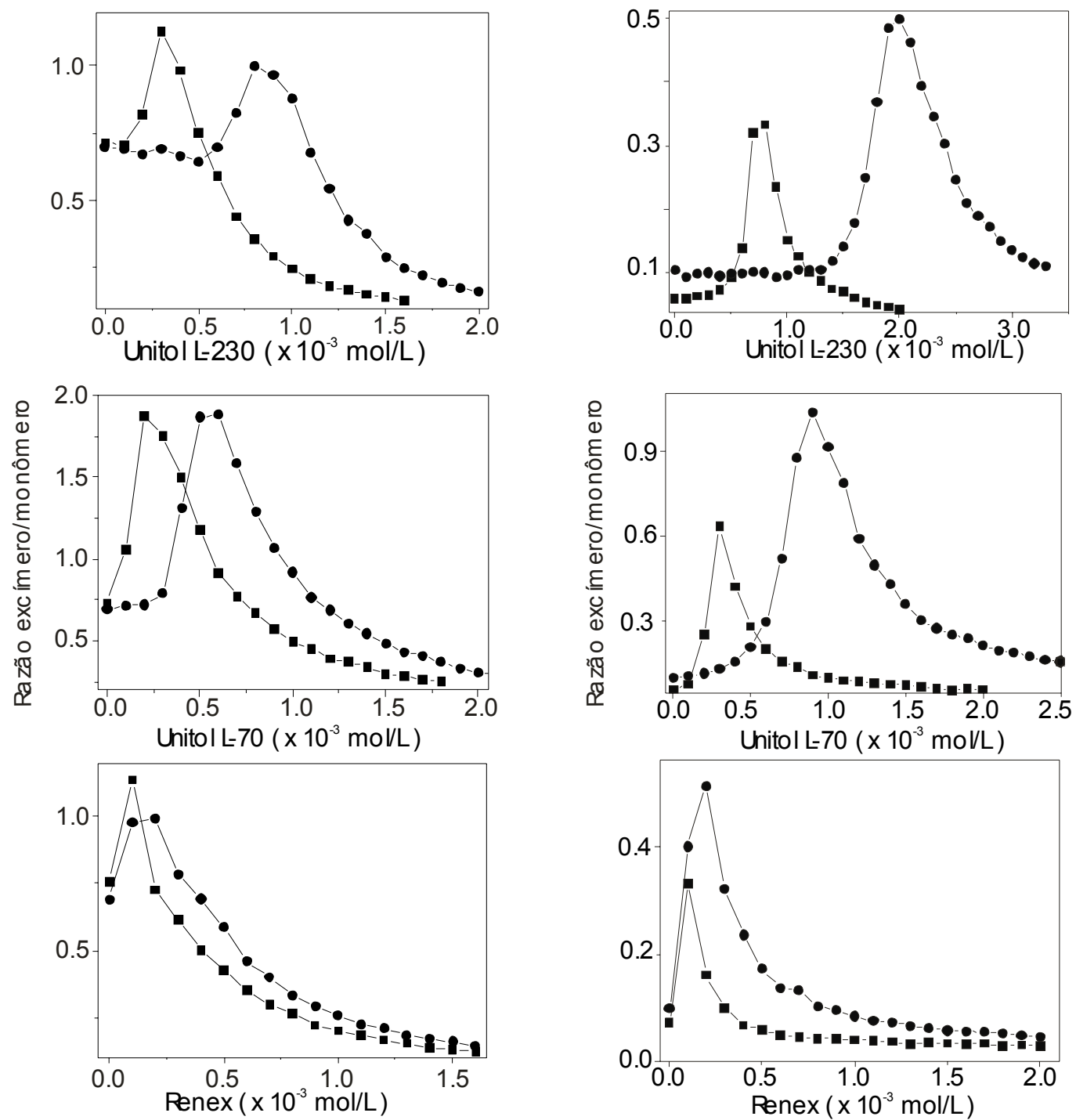

FIGURA 24. Gráficos da razão excímero/monômero do pireno em função de $(A)$ Unitol L-230, (B) Unitol L-70, (C) Renex 95 em soluções de amilopectina ( - - 0,2 \%; - - 1,0 \%). (ESQUERDA) Pireno foi adicionado após o resfriamento da solução. (DIREITA) Pireno foi adicionado durante o preparo da solução. 
Capítulo 4

Se a razão $1 / 3$ do pireno está relacionada com polaridade do microambiente, a emissão de fluorescência do excímero de pireno fornece informações sobre a dinâmica presente no sistema investigado (WINNIK \& REGISMOND, 1996), por exemplo, o processo de dissolução da amilopectina, a associação cooperativa dos surfactantes não-iônicos na estrutura do biopolímero e do processo de micelização. Em especial, o conhecimento do arranjo da conformação da amilopectina e surfactantes não-iônicos é possível, desde que a conformação favoreça ou não a emissão do excímero de pireno.

A emissão de fluorescência centrada em $480 \mathrm{~nm}$ somente será observada se a concentração de moléculas de pireno no meio aumentar. Assim, caso o pireno ocupe regiões diferentes no arranjo proporcionado pela amilopectina em solução, aumentando sua concentração nos microambientes gerados, notaremos facilmente a formação do excímero.

Quando moléculas dos surfactantes não-iônicos são adicionadas à solução de amilopectina, especialmente Unitol, a intensidade da emissão de fluorescência do excímero atinge um valor máximo e então decresce com a concentração de surfactante. Na FIGURA 24, a concentração de surfactante onde a razão excímero/monômero está aumentando, corresponde à cac, enquanto que o máximo coincide com os valores de cmc (TABELA 3). Na FIGURA 24, quando pireno é aquecido juntamente com a amilopectina, a razão excímero/monômero é praticamente constante abaixo da cac e acima da $\mathrm{cmc}$. A máxima razão excímero/monômero é atingida entre esses dois valores.

A explicação para tal comportamento está relacionada com a forma como a sonda foi adicionada à solução de amilopectina. Quando a solução já está fria, o pireno prefere manter-se fora dos clusters de amilopectina e então, mais sensível à concentração de surfactante. Na segunda condição, o pireno está dentro dos clusters de amilopectina. A conformação da amilopectina muda quando moléculas de surfactante são adicionadas a solução. O pireno é liberado para um local mais polar. O resultado total é o aumento da intensidade de emissão do excímero em relação ao monômero antes da cmc. Após a cmc, as micelas do surfactante oferecem um melhor local para a solubilização do pireno.

Outro aspecto importante que a estrutura vibracional permite analisar, são as relações entre suas intensidades como ferramenta auxiliar na interpretação dos 
Capítulo 4

fenômenos de translocação da sonda que estejam ocorrendo no interior dos clusters de amilopectina. Para elucidar e fundamentar um pouco melhor estas hipóteses, realizamos experimentos de fluorescência resolvida no tempo na ausência de surfactante e escolhendo concentrações de tensoativos antes da cac, entre a cac e cmc e superior a cmc, para uma concentração fixa de amilopectina, com o intuito de avaliar o comportamento dinâmico do equilíbrio monômero/excímero do pireno. A partir destes resultados, os tempos de vida do estado excitado das duas espécies foram estimados determinando o decaimento cinético de fluorescência do pireno em comprimentos de onda mais representativos $(373,384 \mathrm{~nm}$ relacionados com o monômero; 425, 474 nm onde há uma possível mistura de emissão do monômero e do excímero e $550 \mathrm{~nm}$, emissão exclusiva do excímero do pireno).

Vale ressaltar que a formação do excímero em agregados micelares depende de vários fatores: número de ocupação de moléculas de pireno em uma dada micela, a mobilidade (relacionada com a microviscosidade) de uma molécula de pireno excitada na micela, e do tempo de vida de uma molécula excitada de pireno em uma micela (TURRO \& KUO, 1986).

Os decaimentos (FIGURA 25) mostraram-se tipicamente como funções monoexponenciais, com exceção dos obtidos para emissão determinada em $425 \mathrm{~nm}$ e $475 \mathrm{~nm}$ para as concentrações de Unitol L-230 de 0,9 e 1,8 mmol/L, respectivamente, entre a cac e cmc e acima da $\mathrm{cmc}$. 
Capítulo 4
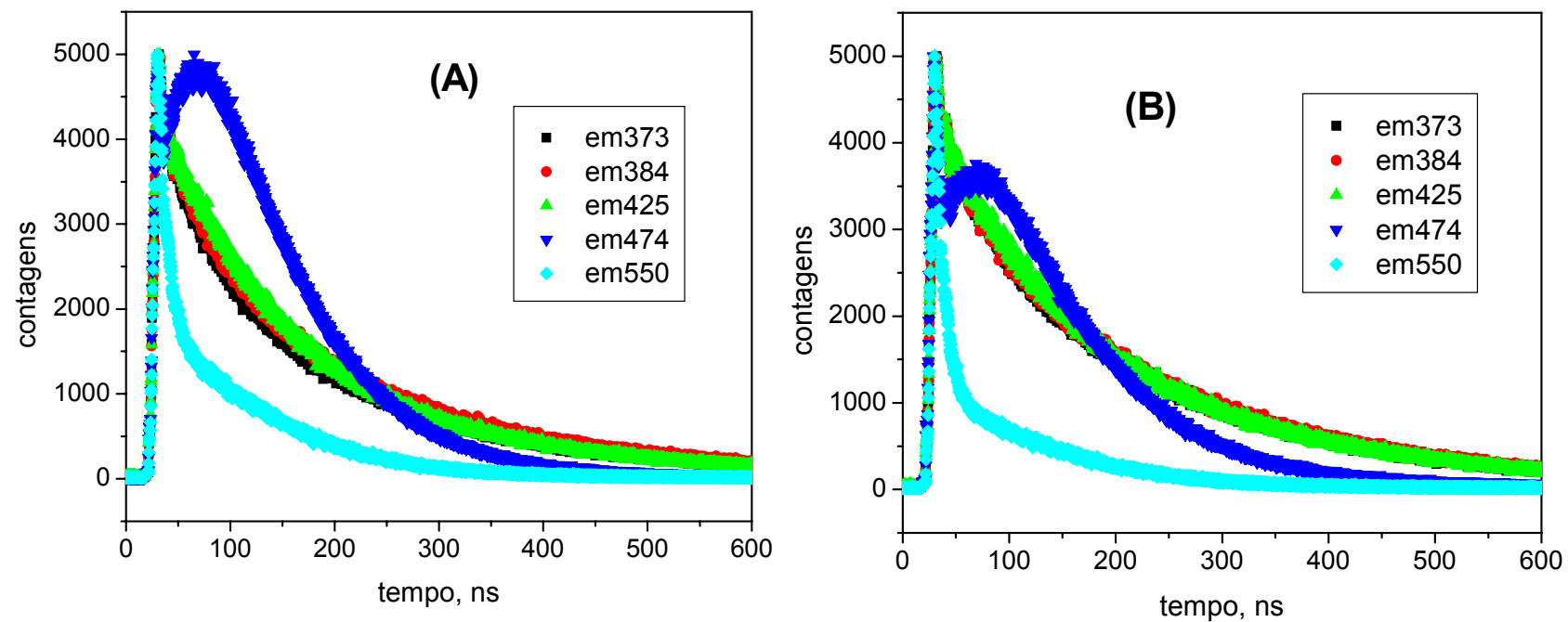

FIGURA 25. Gráficos dos decaimentos cinético de fluorescência do pireno $(1 \mu \mathrm{M})$ em função dos comprimentos de onda de emissão em (A) Unitol L-230 - 0,3 mmol/L,
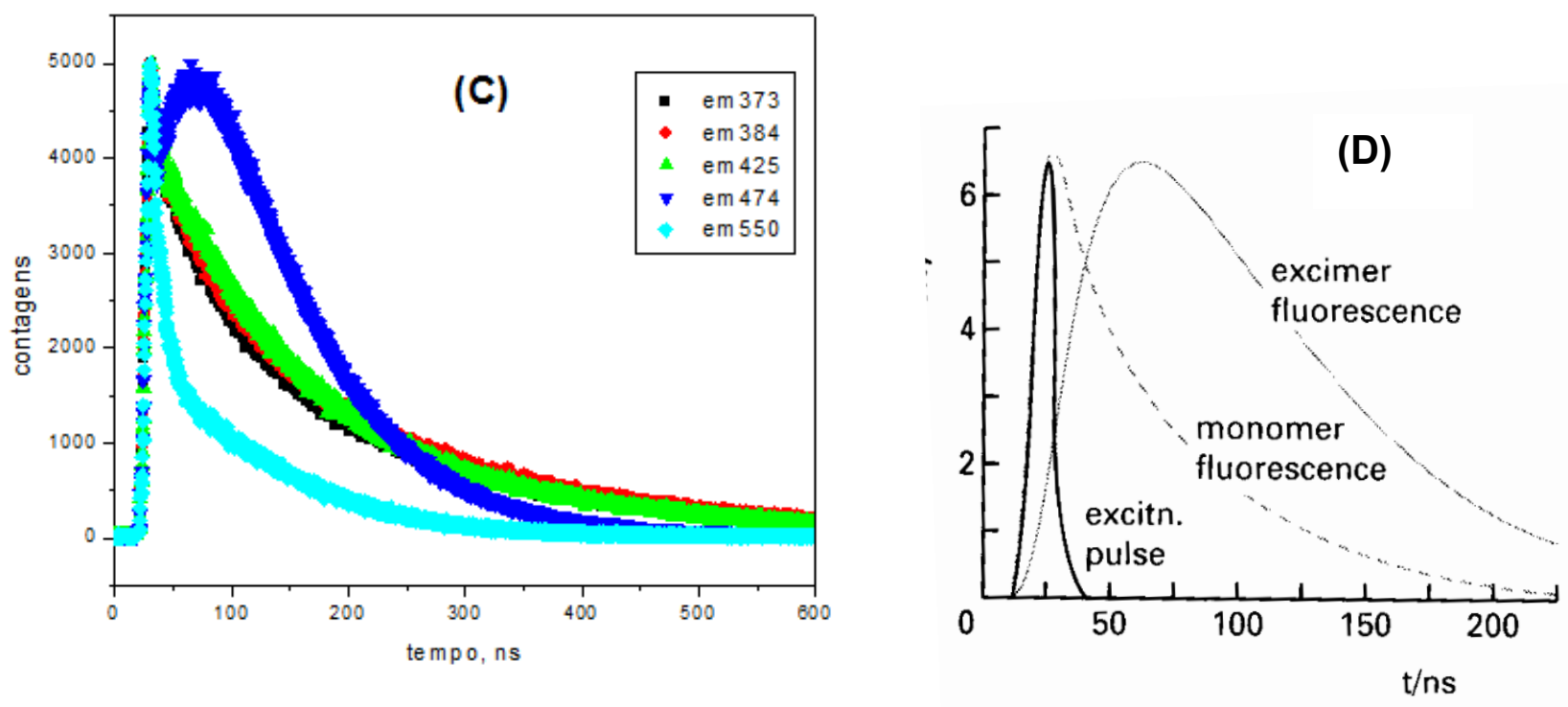

(B) Unitol L-230 - 0,9 mmol/L, (C) Unitol L-230 - 1,8 mmol/L em soluções de amilopectina $1,0 \%$. Pireno foi adicionado durante o preparo da solução. (D) Decaimentos cinéticos do pireno, destacando a emissão do monômero e do excímero (TURRO, 1991).

Os gráficos obtidos são similares àqueles reportados por Turro (1991) (FIGURA 25 D).

Para facilitar a análise, os tempos de vida dos decaimentos cinéticos de fluorescência do pireno estão dispostos na TABELA 5. 
Capítulo 4

TABELA 5. Tempo de vida de fluorescência e amplitudes do pireno, em diferentes concentrações de Unitol L-230 e amilopectina 0,2\%, monitorados em diferentes comprimentos de onda de emissão.

\begin{tabular}{|c|c|c|c|c|c|c|c|c|c|}
\hline \multirow{13}{*}{ 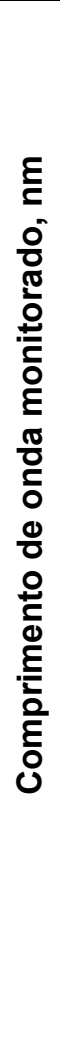 } & & & & \multicolumn{6}{|c|}{ Unitol L-230 } \\
\hline & & \multicolumn{2}{|c|}{ sem surfactante } & \multicolumn{2}{|c|}{$0,3 \mathrm{mM}$} & \multicolumn{2}{|c|}{$0,9 \mathrm{mM}$} & \multicolumn{2}{|c|}{$1,8 \mathrm{mM}$} \\
\hline & & $\tau, \mathbf{n s}$ & $\%$ & $\tau, \mathbf{n s}$ & $\%$ & $\tau, \mathbf{n s}$ & $\%$ & $\tau, \mathbf{n s}$ & $\%$ \\
\hline & \multirow{2}{*}{373} & $142,5 \pm 2,9$ & 84,5 & $145,4 \pm 0,5$ & 94,61 & $200 \pm 0,9$ & 83 & $216 \pm 1$ & 89,28 \\
\hline & & $94,5 \pm 12,4$ & 14,7 & $54 \pm 4$ & 4,59 & $60 \pm 0,9$ & 16 & $66 \pm 2$ & 10,47 \\
\hline & \multirow{2}{*}{384} & $146 \pm 0,47$ & 93,71 & $151,8 \pm 0,9$ & 91,86 & $213 \pm 1$ & 84,8 & $222 \pm 1$ & 89,31 \\
\hline & & $47 \pm 5,53$ & 5,53 & $71 \pm 6$ & 7,29 & $63 \pm 1$ & 14,9 & $68 \pm 2$ & 10,35 \\
\hline & \multirow{2}{*}{425} & $137 \pm 2$ & 70,9 & $140,3 \pm 0,2$ & 96,88 & $280 \pm 9$ & 42,5 & $235 \pm 4$ & 71,33 \\
\hline & & $37 \pm 0,7$ & 28,07 & $10,6 \pm 0,2$ & 3,12 & $115 \pm 1,4$ & 57 & $109 \pm 3$ & 28,34 \\
\hline & \multirow{2}{*}{474} & $3977 \pm 4774$ & 82,57 & $111 \pm 1$ & 39,82 & $252 \pm 0,5$ & 40,2 & $234 \pm 12$ & 82,35 \\
\hline & & $43 \pm 0,14$ & 17,38 & $32,3 \pm 0,6$ & 40,3 & $68 \pm 0,1$ & 59 & $78 \pm 1$ & 14,87 \\
\hline & \multirow{2}{*}{550} & $65,7 \pm 0,5$ & 22,4 & $51,8 \pm 0,6$ & 26,67 & $93,4 \pm 0,15$ & 90,5 & $97,6 \pm 0,2$ & 83 \\
\hline & & $32 \pm 0,26$ & 75,3 & $9,56 \pm 0,1$ & 74,33 & $6,5 \pm 0,07$ & 9,5 & $7 \pm 0,05$ & 17 \\
\hline
\end{tabular}

Na tabela acima é possível observar a discrepância entre o valor estimado para o tempo de vida de fluorescência do excímero, na ausência de surfactante, e os demais valores. A imprecisão na obtenção destes resultados pode ser facilmente justificada em relação aos rendimentos quânticos de fluorescência do excímero quando comparado ao do monômero do pireno. Deste modo, as limitações experimentais prejudicam a estimativa dos tempos de vida, sendo importante considerar, portanto, que pico maior refere-se seguramente à emissão de luz do próprio equipamento.

Tanto no sistema sem surfactante quanto no sistema onde a concentração deste foi mantida abaixo da cac $(0,3 \mathrm{mM})$, observamos a predominância da espécie com tempos de vida em torno de 145 ns. As curvas de decaimento nestes casos foram próximas às curvas monoexponenciais. Este dado refere-se à emissão do monômero do pireno presente nos clusters de amilopectina. Em água pura, o tempo de vida de fluorescência do pireno é aproximadamente 100 ns (TERPETSCHNIG \& JAMESON, 2007). No caso da solução de amilopectina sem adição de surfactante, 
os clusters do biopolímero hospedam o pireno, numa condição que desfavorece a emissão do excímero, apesar da sua baixa existência. Além da polaridade, o número de moléculas de pireno que ocupam os sítios também deve ser considerado. $\mathrm{Na}$ medida em que é adicionado o surfactante e mantendo sua concentração abaixo da cac, inicia-se o processo de migração ou associação cooperativa dos monômeros do surfactante para o esqueleto do biopolímero.

Quando a concentração de surfactante é mantida em 0,9 mM, a contribuição da emissão do excímero aumenta e os valores dos tempos de vida se alteram. Neste momento, já foi atingida a cac do sistema e, portanto, o pireno migra para os agregados polímero-surfactante formados. Como a polaridade destes agregados é menor que a dos clusters, aumenta-se o número de moléculas de pireno nestes sítios e conseqüentemente, favorece-se o equilíbrio de formação do excímero. Conseqüentemente, a razão excímero/monômero também aumenta.

Já quando a concentração de surfactante está acima da cmc (1,8 mM), diminuise a contribuição da emissão do excímero. O tempo de vida de fluorescência do monômero, novamente sofre um acréscimo, atingindo valores maiores que $210 \mathrm{~ns}$, correspondentes ao valor do tempo de vida em sistemas micelares (KALYANASUNDARAM, 1987). Neste momento, concluímos que o pireno migra para um novo sítio de polaridade menor que a dos clusters ou dos agregados, neste caso, micelas livres.

Um dado que tratamos separadamente diz respeito às cinéticas de formação do excímero cujos tempos de vida foram estimados em 1,54 e 1,12 $\mu$ s para as soluções com concentração de Unitol L-230 de 0,9 mM e 1,8 mmol/L, respectivamente. Os valores foram calculados, considerando-se um crescimento monoexponencial nas curvas obtidas.

Como já mencionado, os tamanhos dos clusters de amilopectina (cerca de 19 Å) e as micelas dos surfactantes não-iônicos podem comportar pequenas moléculas. Se assumirmos a dimensão da molécula de pireno como sendo o tamanho do mais longo eixo molecular ( $7 \AA$ ), pode-se dizer que a dimensão tanto dos clusters quanto das micelas são suficientemente grandes para comportar uma molécula. Apesar de não terem sido realizadas medidas de tempo de vida para todos os surfactantes estudados, podemos realizar algumas aproximações. Como não foram observadas 
Capítulo 4

variações significativas para a razão 1/3 das bandas de emissão do pireno para os diferentes surfactantes, é de se esperar que os tempos vida e os decaimentos sejam semelhantes. Esses resultados mostram que a sensibilidade do pireno à polaridade desses meios está diretamente relacionada com essas dimensões e que, portanto, sua sensibilidade é de curta distância.

Os resultados permitem ainda visualizar comportamentos específicos, apesar das concentrações de surfactante estarem acima dos valores estimados para a cmc. Inicialmente, podemos observar que quanto o maior a concentração de surfactante, maior o tempo de vida de fluorescência da espécie monomérica. Tal fato era de se esperar, uma vez que o pireno se solubilizará melhor em ambientes apolares, como os gerados pelas micelas do surfactante. Deste modo, a dinâmica do equilíbrio monômero-excímero é facilmente afetada.

Quando a concentração de surfactante é mantida em torno de 0,9 mM, a desativação do excímero é mais rápida, enquanto que a cinética de desativação do monômero é mais lenta. De alguma forma, a associação cooperativa entre os monômeros do surfactante e o corpo do biopolímero é favorecida nesta concentração. Além disso, é possível notar na FIGURA 25 que as cinéticas de formação do excímero teriam um tempo de vida de 1,54 e 1,12 $\mu$ s para as soluções com concentração de Unitol L-230 de 0,9 e 1,8 mmol/L, respectivamente.

As ramificações da amilopectina em associação com os monômeros do surfactante geram uma estrutura supramolecular a qual interfere nas rotas fotofísicas de desativação do pireno excitado.

Em geral, há uma boa correspondência entre o tamanho e a forma do cluster e das micelas e as dimensões moleculares da molécula de pireno. Neste caso, os grupos polares dos agregados estão o mais próximo possível das moléculas de pireno. Esta organização do polímero em torno da sonda, tendo sido denominada por Varlot (2001) de "gaiola dinâmica".

Como conseqüência, quando o caminho preferencial de desativação das sondas fluorescentes ocorre por rotação interna da sonda, a redução de mobilidade causada pela rigidez do ambiente aumenta a eficiência de emissão de fluorescência e o tempo de vida do estado excitado (ROYAL, 1993). Dessa forma, o tamanho do 
Capítulo 4

elemento de rotação na sonda determinará a extensão da sensibilidade da mesma à mobilidade da matriz polimérica.

Vale ressaltar que a mobilidade da sonda é fortemente dependente do tamanho, sondas maiores tendem a ser menos sensíveis a pequenas mudanças de volume livre que ocorrem quando a relaxação do polímero envolve segmentos pequenos. A diminuição do volume livre produz aumento da intensidade de fluorescência. De forma similar, pode-se determinar que os volumes livres próximos às extremidades da cadeia é maior do que nos centros (MEYER, 1990).

As principais conclusões que poderíamos retirar de todos os dados obtidos desta parte do trabalho seriam: (1) é necessário considerar que o microambiente comporte pelo menos duas moléculas de pireno e que favoreça tanto os movimentos de rotação e translação entre estas moléculas, para que se forme o excímero. (2) A cinética de entrada e saída do pireno destes microambientes carece de estudos com concentrações mais baixas de pireno e concentrações de surfactantes abaixo da cmc, contudo, as técnicas utilizadas começam a se tornarem limitadas. (3) O tempo de vida do monômero excitado e suas características difusionais determinam a eficiência de formação do excímero na micela duplamente ocupada. (4) Quanto maior o número de moléculas de pireno na micela maior a probabilidade de formação do excímero, que se combina com o fato de que quanto menor o número de micelas, maior a probabilidade de encontrar uma micela multiplamente ocupada.

\subsubsection{ESTUDOS COM O CORANTE DE REICHARDT}

A polaridade dos microambientes pode também ser avaliada empregando do corante de Reichardt, utilizado para investigar micelas e lipossomos (DRUMMOND, GRIESER \& HEALY, 1986). O tamponamento da solução com tampão borato, $\mathrm{pH}=$ 9,0, evita a protonação do oxigênio fenóxido (REICHARDT, 1992). Assim, por exemplo, o deslocamento da banda solvatocrômica do corante a $453 \mathrm{~nm}$ em meio aquoso para $810 \mathrm{~nm}$ em eter difenílico (REICHARDT \& HARBUSCH-GORNET, 1983) pode ser atribuído ao processo de transferência de carga do átomo de oxigênio fenóxido para o solvente. 
Capítulo 4

Neste trabalho, o corante foi aquecido juntamente com a solução de amilopectina para reproduzir as condições experimentais utilizados no preparo de amostras com o pireno. As soluções investigadas incluíram água, amilopectina 1,0\% e surfactantes a 30 $\mathrm{mmol} / \mathrm{L}$. Os resultados confirmam a formação dos complexos amilopectina-surfactantes. Os valores de $E_{\top} 30$ (TABELA 6) foram também determinados na presença de amilopectina 1,0\% e concentrações de surfactantes entre a cac e cmc.

TABELA 6. Comprimentos de onda máximos de absorção de soluções do corante de Reichardt, a $25^{\circ} \mathrm{C}$.

\begin{tabular}{lll}
\hline Sistema & $\lambda_{\max }(\mathbf{n m})$ & $\mathbf{E}_{\mathrm{T}} \mathbf{3 0}$ \\
\hline Água & 456 & 62,7 \\
Amilopectina 1,0 \% & 514 & 55,6 \\
Amilopectina 1,0 \% / Renex 95, 0,20 mmol/L & 518 & 55,2 \\
Amilopectina 1,0 \% / Unitol L-70, 0,80 mmol/L & 518 & 55,2 \\
Amilopectina 1,0 \% / Unitol L-230, 1,90 mmol/L & 518 & 55,2 \\
Renex 95, $30 \mathrm{mmol} / \mathrm{L}$ & 562 & 50,9 \\
Unitol L-70, $30 \mathrm{mmol} / \mathrm{L}$ & 564 & 50,7 \\
Unitol L-230, 30 mmol/L & 562 & 50,9 \\
Amilopectina 1,0 \% / Renex 95, 30 mmol/L & 560 & 51,1 \\
Amilopectina 1,0 \% / Unitol L-70, 30 mmol/L & 562 & 50,9 \\
Amilopectina 1,0 \% / Unitol L-230,30 mmol/L & 562 & 50,9 \\
\hline
\end{tabular}

O microambiente da amilopectina $(55,6)$ é muito similar ao etilenoglicol $(54,9)$ (REICHARDT \& HARBUSCH-GORNET, 1983). Este era um resultado esperado uma vez que várias unidades de glicose estão presentes na estrutura da amilopectina. Evans e colaboradores (1999) utilizam das propriedades de polaridade do estado triplete excitado da xantona para estudar ciclodextrinas e outros solventes. Ciclodextrinas, oligossacarídeos de glicose, possuem a mesma polaridade do etilenoglicol.

No sistema surfactante-biopolímero, entre a cac e a cmc, o corante mostrou uma polaridade similar aos clusters de amilopectina $(55,2)$. Após a cmc, independente da presença ou ausência da amilopectina, a polaridade $(50,7-51,1)$ é similar a soluções de metanol (51,9) (REICHARDT \& HARBUSCH-GORNET, 1983). As cadeias de polioxietileno produzem sítios de solubilização similares a alguns álcoois alquílicos. Os valores de $\mathrm{E}_{\top} 30$ para $\mathrm{O}$ etanol e o butanol são respectivamente, 45,6 e 47,1 (REICHARDT \& HARBUSCH-GORNET, 1983). 
Capítulo 4

\subsubsection{DETERMINAÇÃO DE N}

O método de supressão de fluorescência proposto por Turro e Yekta (1978) foi utilizado para determinar o número de agregação micelar médio, N, empregando $\mathrm{CPCl}$ como supressor e pireno como sonda fluorescente.

A FIGURA 26 apresenta um gráfico representativo das curvas $\ln F / F_{0}$ em função da concentração do supressor. Os números de agregação micelar estimados para situações onde a concentração de tensoativo foi mantida constante $(3 \mathrm{mmol} / \mathrm{L})$ ou variável na presença de amilopectina são apresentados nas TABELAS 3 e 7, respectivamente.

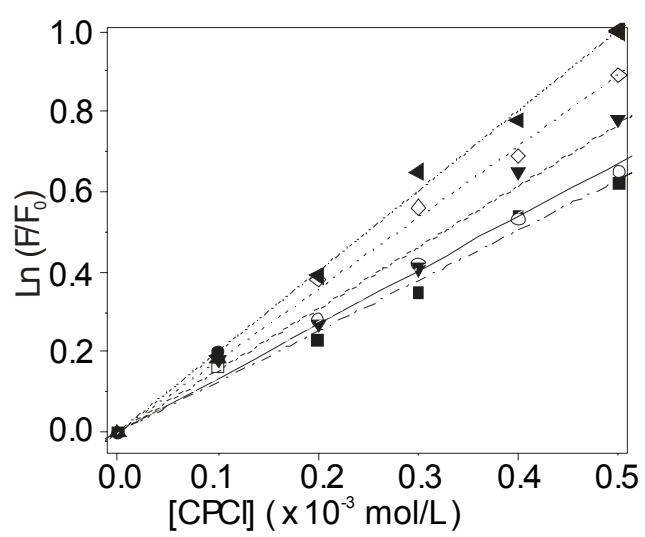

FIGURA 26. Gráfico da supressão de emissão de fluorescência do pireno em Unitol $L-230(\boldsymbol{\bullet}, 0 ; 0,0.4 ;-, 0.6 ; \diamond, 0.8$; and $\bullet, 1,0 \%)$ amilopectina a $25^{\circ} \mathrm{C}$.

TABELA 7. $\quad N$ para o sistema tensoativo Unitol/amilopectina, empregando o procedimento de aquecimento da sonda e do biopolímero.

\begin{tabular}{ccccc}
\hline Amilopectina, \% m/m & $\begin{array}{c}\text { Unitol L-70 } \\
(\mathbf{m m o l} / \mathbf{L})\end{array}$ & $\mathbf{N}$ & $\begin{array}{c}\text { Unitol L-230 } \\
(\mathbf{m m o l} / \mathbf{L})\end{array}$ & $\mathbf{N}$ \\
\hline 0,2 & 0,25 & 56 & 0,70 & 60 \\
0,4 & 0,50 & 57 & 0,90 & 57 \\
0,6 & 0,55 & 54 & 1,10 & 59 \\
0,8 & 0,60 & 59 & 1,50 & 65 \\
1,0 & 0,80 & 65 & 1,90 & 69 \\
\hline
\end{tabular}

A TABELA 3 mostra $\mathrm{N}_{\mathrm{ag}}$ de 92 e 67 para o Unitol L-230 e Renex 95, respectivamente. O valor é maior que o reportado por Tóth e Madarász (2006) reavaliado por simulações tipo Monte-Carlo a partir de medidas de espalhamento de 
Capítulo 4

nêutrons. O número de agregação é dependente da concentração e da temperatura. Neste trabalho, a fonte do surfactante não-iônico também pode fazer a diferença, uma vez que não foram realizadas purificações. Por outro lado, o $\mathrm{N}_{\mathrm{ag}}$ para o Renex 95 (67) é bastante próximo ao do nonilfenol etoxilado EO(5) (72) (GHOSH, KHATUA \& BHATTACHARYA, 2004). Esses valores também se aproximam dos já publicados, quando se analisamos os outros biopolímeros (2-hidroxietilamido e carboximetilcelulose), confirmando a não associação destes com os surfactantes.

A presença da amilopectina com Renex não afeta o N (67-71), independente do método de preparação das soluções (TABELA 3) Este resultado também confirma a ausência de uma ligação cooperativa do surfactante não-iônico com amilopectina.

Para o Unitol (L-70 e L-230), há resultados distintos. Quando o pireno é adicionado após a formação dos clusters de amilopectina, mantendo a concentração de surfactante constante em $3 \mathrm{mmol} / \mathrm{L}, \mathrm{N}_{\mathrm{ag}}$ independe da concentração de amilopectina (TABELA 3). $\mathrm{N}_{\text {ag }}$ é $77 \pm 3$ para o Unitol L-70 e $95 \pm 3$ para Unitol L-230. O outro caso é observado quando o pireno é adicionado antes da formação dos clusters, e a concentração de surfactante está acima da cmc (TABELA 3). Nesta situação o pireno já está solubilizado preferencialmente nas micelas não-iônicas. Contudo, o complexo amilopectina-surfactante/não-iônico não pode ser totalmente excluído na solubilização do pireno. O supressor não consegue distinguir tais condições. Desde que a difusão das moléculas é perturbada pela estrutura ramificada da amilopectina (GALINSKY \& BURCHARD, 1997), o número de agregação médio determinado é diretamente dependente da concentração de amilopectina. Quando a concentração de amilopectina aumenta, $\mathrm{N}_{\mathrm{ag}}$ aumenta. Este fato pode ser comprovado com os resultados da TABELA 7. No último caso, a concentração de Unitol foi mantida entre a cac e a cmc. Por esta razão, $\mathrm{N}_{\mathrm{ag}}$ para ambos surfactantes está na mesma faixa $58 \pm 4$ (L-70) e $62 \pm 5$ (L230). Geralmente, sistemas formados por complexo polímero-surfactante apresentam valores menores de $\mathrm{N}_{\mathrm{ag}}$ (SILVÉRIO \& OKANO, 2004; NASSAR et al., 1995). 
Capítulo 4

\subsubsection{EFEITO DA TEMPERATURA}

A cmc foi determinada em várias temperaturas. Mudanças na energia livre de Gibbs associada com o processo de micelização são estimados de $\Delta \mathrm{G}_{\mathrm{m}}^{0}=$ RTIn(cmc), considerando uma concentração fixa de amilopectina, 0,2 \% (TABELA 8).

TABELA 8. $\quad C m c$ e energia livre de Gibbs para o processo de micelização a diferentes temperaturas.

\begin{tabular}{|c|c|c|c|c|c|c|}
\hline \multirow[b]{2}{*}{ Temperatura $\left({ }^{\circ} \mathrm{C}\right)$} & \multicolumn{2}{|c|}{ Unitol L-70 } & \multicolumn{2}{|c|}{ Unitol L-230 } & \multicolumn{2}{|c|}{ Renex 95} \\
\hline & $\begin{array}{c}\mathrm{cmc} \\
(\mathrm{mmol} / \mathrm{L})\end{array}$ & $\begin{array}{c}-\Delta G^{0}{ }_{m} \\
(\mathrm{~kJ} / \mathrm{mol})\end{array}$ & $\begin{array}{c}\mathrm{cmc} \\
(\mathrm{mmol} / \mathrm{L})\end{array}$ & $\begin{array}{c}-\Delta G_{m}^{0} \\
(\mathrm{~kJ} / \mathrm{mol})\end{array}$ & $\underset{(\mathrm{mmol})}{\mathrm{cmc}}$ & $\begin{array}{c}-\Delta G^{0}{ }_{m} \\
(\mathrm{~kJ} / \mathrm{mol})\end{array}$ \\
\hline 20 & 0,30 & 2,93 & 0,78 & 0,71 & 0,11 & 5,38 \\
\hline 25 & 0,30 & 2,98 & 0,74 & 0,65 & 0,11 & 3,47 \\
\hline 30 & 0,28 & 3,21 & 0,72 & 0,83 & 0,14 & 4,95 \\
\hline 35 & 0,30 & 3,08 & 0,74 & 0,77 & 0,12 & 5,43 \\
\hline 40 & 0,25 & 3,61 & 0,65 & 1,12 & 0,13 & 5,31 \\
\hline 45 & 0,22 & 4,00 & 0,62 & 1,26 & 0,14 & 5,20 \\
\hline
\end{tabular}

Quando um grupo principal do surfactante é transferido da água para o agregado micelar, a mudança na energia livre é maior, resultando numa força que favorece a formação da micela. Os dados continuam a indicar que a micelização do Renex é independente da temperatura, e as micelas normais de Renex se formam.

Esta grandeza constitui uma medida conveniente da força de interação entre o surfactante e o polímero. Vale ressaltar, por um ponto de vista até mesmo do senso comum, que seria impossível ter uma cac maior do que a $\mathrm{cmc}$ do surfactante. Neste caso, as moléculas do surfactante prefeririam formar micelas livres ao invés de se ligar ao polímero. Portanto, quando o polímero interage com a micela, a energia livre do processo de micelização e, conseqüentemente a cmc sejam menores. Entretanto, nem sempre uma diminuição do valor da cmc indica uma interação efetiva entre monômeros de tensoativos e esqueleto polimérico, para a formação de um complexo efetivo entre o polímero e o surfactante. Por exemplo, adição de sal ou de um polietrólito de mesma carga de um surfactante iônico também reduz a cmc. Assim, determinações mais precisas necessitam serem exploradas. 
Capítulo 4

É possível notar ainda, que os surfactantes de Unitol formam micelas preferencialmente em temperaturas mais altas e o menor índice de unidades oxietileno (L-70) favorece a micelização. Este resultado está de acordo com o papel de resíduos do óxido de etileno na formação da micela (TURRO \& YEKTA, 1978). Tentou-se realizar medidas de microcalorimetria para melhor fundamentar estes resultados. Porém, como o polímero e os tensoativos estudados não possuem cargas elétricas, não foi possível obter com confiança alguma variação razoável entre estas medidas. 
Capítulo 5

\section{CAPÍTULO 5}

\subsection{COMPORTAMENTO FOTOFÍSICO DA XANTONA EM SOLUÇÕES DE AMILOPECTINA}

Devido a sua estrutura, a amilopectina possui uma tendência para formar agregados insolúveis em soluções aquosas (ZHONG, YOKOYAMA \& WANG, 2006). Por este motivo, optou-se pelo método descrito em Naganine \& Konae (1996) para melhor dispersão do polímero em água. Basicamente, o método consistiu no preparo das soluções de amilopectina em soluções aquosas saturada de xantona em frascos com tampas. Estes frascos foram mantidos sob agitação e aquecidos a $80{ }^{\circ} \mathrm{C}$ por meia hora. Posteriormente, ocorreu o resfriamento natural à temperatura ambiente, mantendo-se a agitação durante 24 horas antes da realização das medidas experimentais. Entretanto, apesar da utilização deste método, soluções contendo concentrações superiores a $0,7 \%(\mathrm{~m} / \mathrm{v})$ de amilopectina não se solubilizaram totalmente.

A FIGURA 27 apresenta os espectros de emissão de fluorescência da xantona em água e em diferentes concentrações de amilopectina, sob duas condições: (1) agitação do sistema por 24 horas e (2) agitação por 72 horas. 

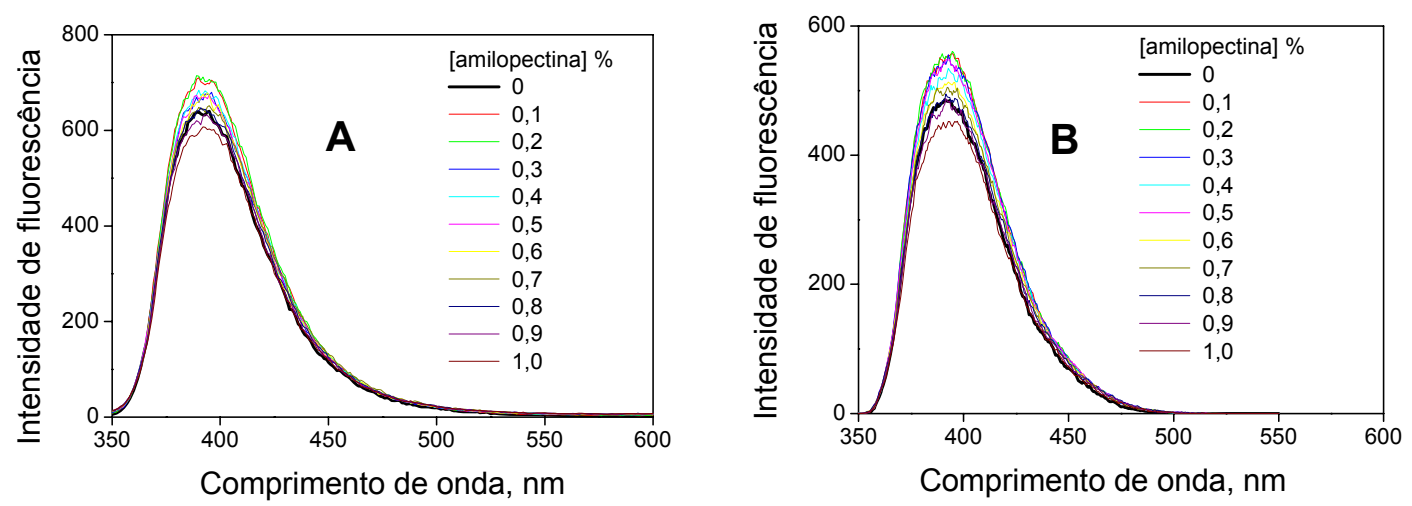

FIGURA 27. Espectros de emissão de fluorescência da xantona em água e em diferentes concentrações de amilopectina, $\lambda_{\text {exc }}=340 \mathrm{~nm}$. $f 1=f 2=5 \mathrm{~nm}$. (A) Agitação por 24 horas; (B) Agitação por 72 horas.

Comparando os espectros de emissão na presença de amilopectina com o obtido da solução saturada de xantona em água notou-se que houve um favorecimento da emissão de fluorescência para as concentrações de amilopectina inferiores a $0,7 \%(\mathrm{~m} / \mathrm{m})$. Nas demais condições analisadas, observou-se que a intensidade de fluorescência sofreu a interferência da turvação das soluções preparadas.

Para facilitar a interpretação, os comportamentos observados para o máximo de emissão de fluorescência da xantona nas condições estudadas são apresentados na FIGURA 28.
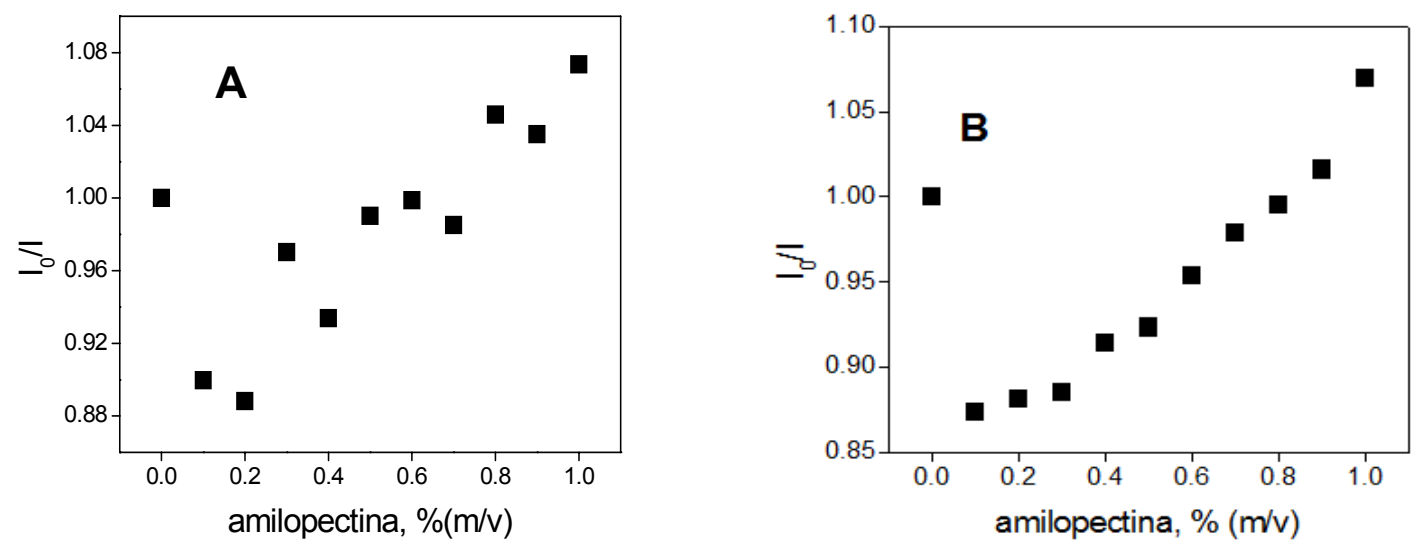

FIGURA 28. Razão $I_{d} l l$ (Intensidade de fluorescência em $392 \mathrm{~nm}$ de solução saturada de xantona em água $\left(I_{0}\right)$ e na presença de amilopectina(I)). (A) Agitação por 24 horas, (B) por 72 horas. 
Capítulo 5

Os gráficos permitem observar que a solução mantida sob agitação por 72 horas apresenta uma melhor tendência, contudo, não há significativas mudanças quanto à intensidade de fluorescência da xantona. Em concentrações mais baixas do biopolímero, haveria uma melhor mobilidade da sonda em solução de forma similar ao pireno (MIRANDA, CACITA \& OKANO, 2007), o que justificaria as alterações nas intensidades de fluorescência. Entretanto, verificou-se que a medida que a concentração do biopolímero aumenta, a tendência da sonda em solução é manter-se no ambiente aquoso.

\subsubsection{MEDIDAS DE FLUORESCÊNCIA EM PICOSEGUNDOS DA XANTONA} EM SOLUÇÕES AQUOSAS DE AMILOPECTINA

As medidas experimentais de fluorescência resolvida no tempo na escala de picosegundos foram realizadas com as soluções claras ou ligeiramente turvas, excitando-se em $304 \mathrm{~nm}$ e coletando-se a emissão em $390 \mathrm{~nm}$. Estas soluções forneceram os gráficos descritos FIGURA 29. Todas as soluções contendo amilopectina puderam ser ajustadas como decaimentos biexponenciais com uma boa redução dos quadrados mínimos não-lineares $\left(X^{2}\right)$. 
Capítulo 5
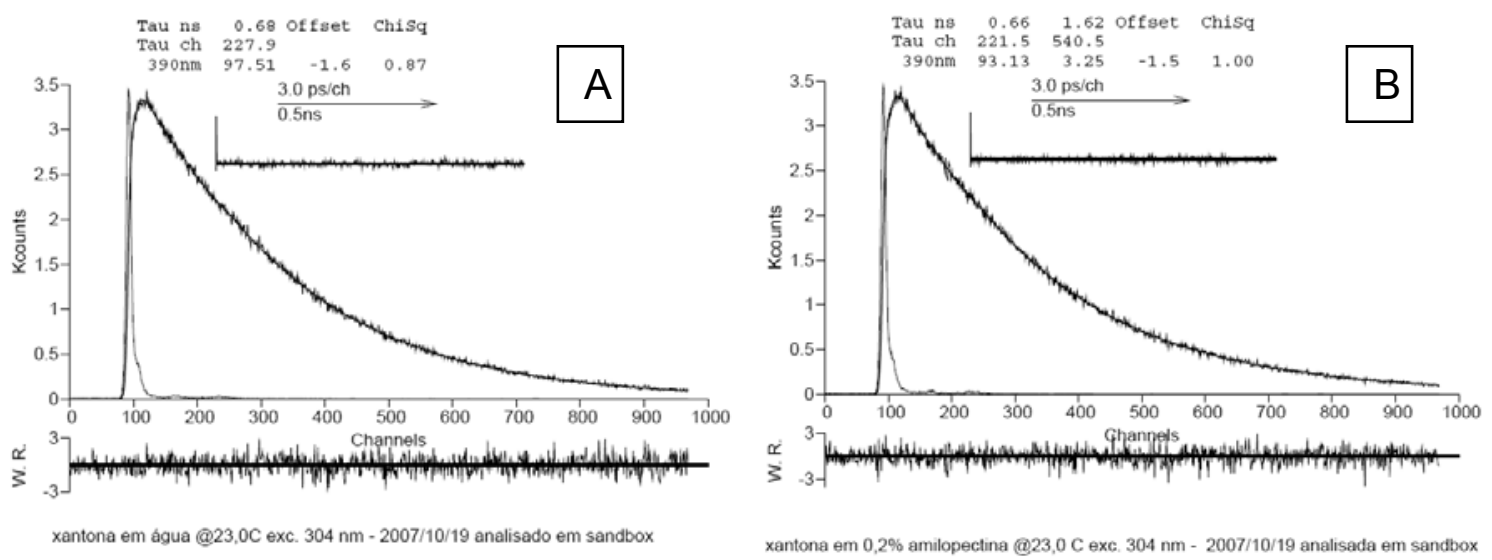



$390 \mathrm{~nm} \quad 85.82 \quad 9.82 \quad-1.5 \quad 1.07$
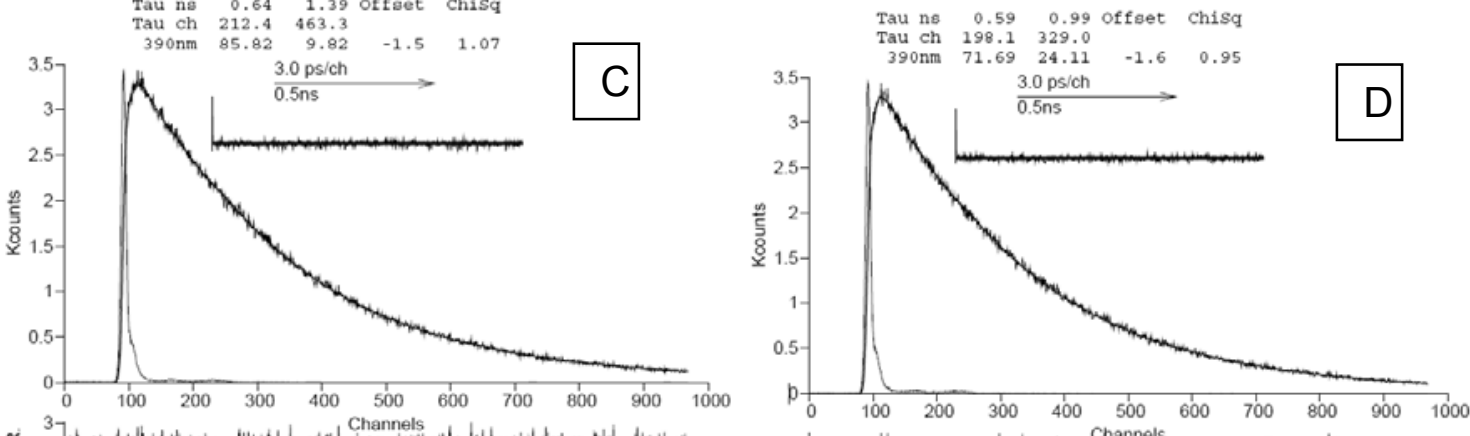

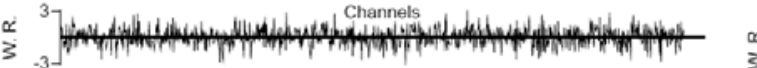

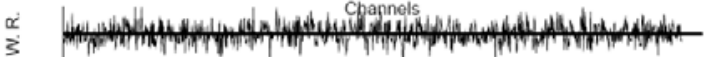

xantona em 0,5\% amilopectina @23,0C exc. $304 \mathrm{~nm}$ - 2007/10/19 analisado em sandbox xantona em 0,7\% amilopectina @23,0C exc. 304 nm - 2007/10/19 analisado em sandbox $\begin{array}{llll}\text { Tau ns } & 0.52 & 0.93 \text { offset Chisq }\end{array}$

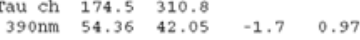

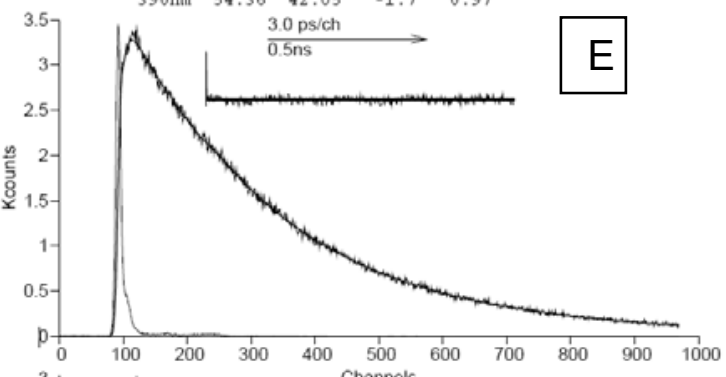

Tau ns $0.58 \quad 1.03$ offset chisg

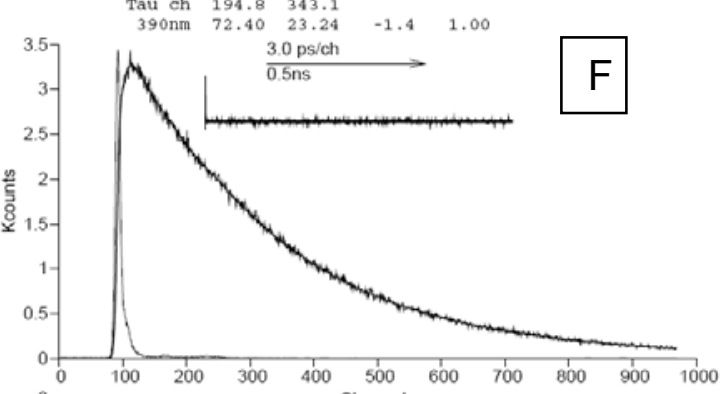

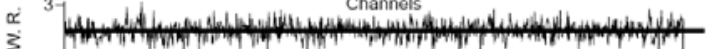

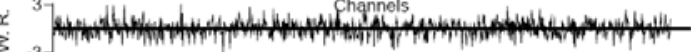

xantona em 1,0\% amilopectina @23,0 C exc. $304 \mathrm{~nm}$ - 2007/10/19 analisado em sandbox xantona em 1,2\% amilopectina @23,0C exc. $304 \mathrm{~nm}$ - 2007/10/19 analisado em sandbox

FIGURA 29. Decaimentos cinéticos de fluorescência da xantona na ausência e presença de diferentes concentrações de amilopectina. $(A)$ em água, (B) 0,2; (C) 0,5; (D) 0,7; (E) 1,0 e (F) 1,2\% de amilopectina. 
Capítulo 5

O resultado da análise global da xantona em água e em diferentes concentrações de amilopectina é apresentado na FIGURA 30.

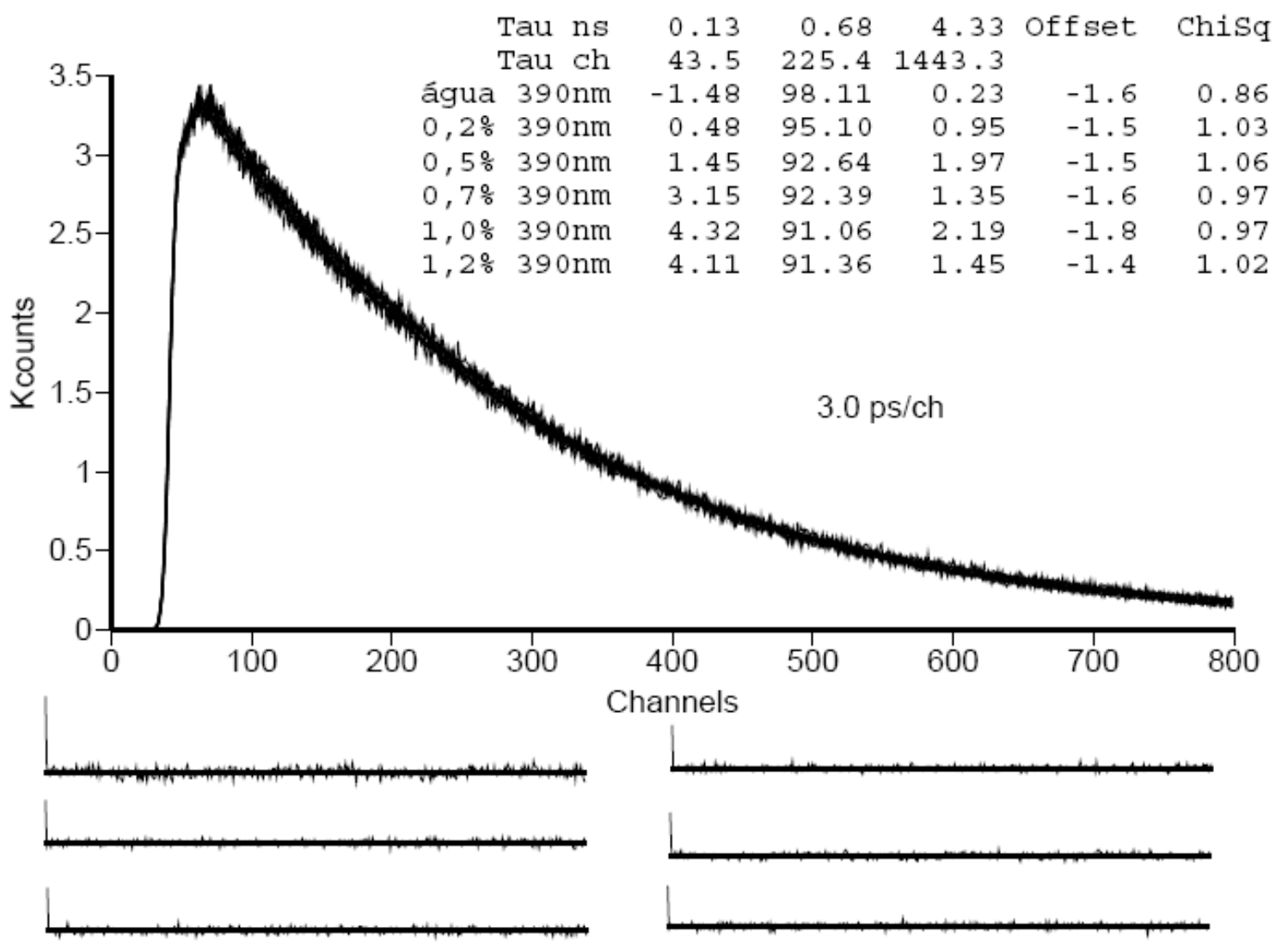

FIGURA 30. Análise global da xantona na presença de concentração variável de amilopectina.

Os tempos de vida obtidos estão descritos na Tabela 9. Nesta tabela, assumiuse como peso molecular da amilopectina em estudo como sendo $2 \times 10^{6} \mathrm{~g} / \mathrm{mol}^{3}$.

${ }^{3}$ Valor determinado por Fabiano de Almeida Silva no Laboratório de Catálise da Faculdade de Engenharia Química da UFU utilizando espalhamento estático de luz. Este valor esteve próximo ao estimado por Yang et al., (2006), 1,5 x 10 $\mathrm{g} / \mathrm{mol}$ 
Capítulo 5

TABELA 9. Valores de tempo de vida da xantona na presença de concentração variável de amilopectina

\begin{tabular}{ccccccc}
\hline $\begin{array}{c}\text { Amilopectina } \\
(\%)\end{array}$ & $\begin{array}{c}\text { Amilopectina } \\
(\mathbf{m o l} / \mathbf{L})\end{array}$ & $\mathbf{T}_{\mathbf{1}}(\mathbf{n s})$ & $\mathbf{T}_{\mathbf{2}}(\mathbf{n s})$ & $\mathbf{1 / \mathbf { T } _ { 1 } ( \mathbf { s } ^ { - 1 } )}$ & $\mathbf{1 / \mathbf { T } _ { 2 } ( \mathbf { s } ^ { - 1 } )}$ & $\mathbf{1 / \mathbf { T } _ { 1 } + 1 / \mathbf { T } _ { 2 } ( \mathbf { s } ^ { - 1 } )}$ \\
\hline 0 & 0 & 0,68 & & $1,47 \times 10^{9}$ & & $1,47 \times 10^{9}$ \\
0,20 & $1,0 \times 10^{-6}$ & 0,66 & 1,62 & $1,52 \times 10^{9}$ & $6,17 \times 10^{8}$ & $2,13 \times 10^{9}$ \\
0,50 & $2,5 \times 10^{-6}$ & 0,64 & 1,39 & $1,56 \times 10^{9}$ & $7,19 \times 10^{8}$ & $2,28 \times 10^{9}$ \\
0,70 & $3,5 \times 10^{-6}$ & 0,59 & 0,99 & $1,69 \times 10^{9}$ & $1,01 \times 10^{9}$ & $2,71 \times 10^{9}$ \\
1,0 & $5,0 \times 10^{-6}$ & 0,52 & 0,93 & $1,92 \times 10^{9}$ & $1,08 \times 10^{9}$ & $3,00 \times 10^{9}$ \\
1,2 & $6,0 \times 10^{-6}$ & 0,58 & 1,03 & $1,72 \times 10^{9}$ & $9,71 \times 10^{8}$ & $2,70 \times 10^{9}$ \\
\hline
\end{tabular}

A relação entre os tempos de vida da xantona e a concentração do polímero fornece os gráficos da FIGURA 31.
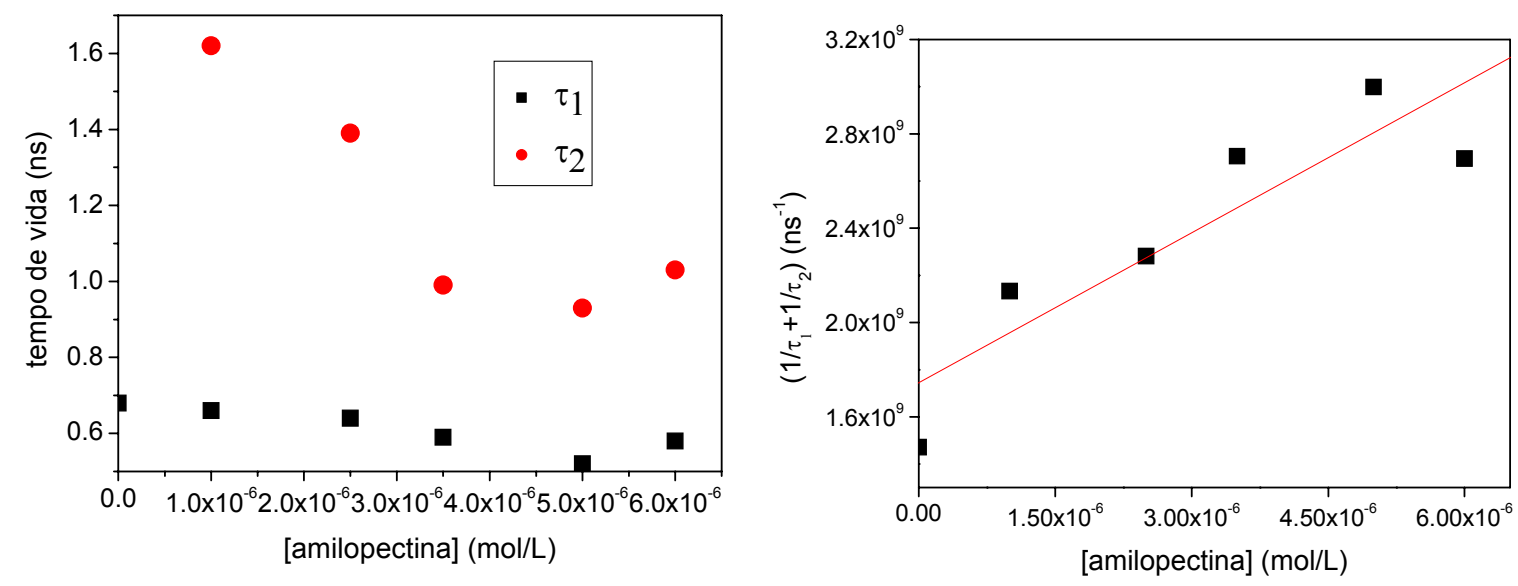

FIGURA 31. Relação entre componentes do tempo de vida da xantona em função da concentração da amilopectina.

Os gráficos da FIGURA 29 forneceram também os valores das amplitudes relacionadas a cada componente do tempo de vida da xantona em soluções de amilopectina. Os dados de amplitude e sua normalização estão mostrados na TABELA 10. A FIGURA 32 exibe o comportamento das amplitudes em função da concentração de amilopectina. 
Capítulo 5

TABELA 10. Valores das amplitudes (A) dos tempos de vida da xantona na presença de concentração variável de amilopectina, e os valores normalizados $\left(A_{n}\right)$.

\begin{tabular}{ccccccc}
\hline $\begin{array}{c}\text { Amilopectina } \\
\text { (mol/L) }\end{array}$ & $\mathbf{T}_{\mathbf{1}}(\mathbf{n s})$ & $\mathbf{T}_{\mathbf{2}}(\mathbf{n s})$ & $\mathbf{A}_{\mathbf{1}}$ & $\mathbf{A}_{\mathbf{2}}$ & $\mathbf{A}_{\mathbf{n} 1}$ & $\mathbf{A}_{\mathbf{n} 2}$ \\
\hline 0 & 0,68 & & 1 & & 1 & \\
$1,0 \times 10^{-6}$ & 0,66 & 1,62 & 93,13 & 3,25 & 0,966 & 0,034 \\
$2,5 \times 10^{-6}$ & 0,64 & 1,39 & 85,82 & 9,82 & 0,897 & 0,103 \\
$3,5 \times 10^{-6}$ & 0,59 & 0,99 & 71,69 & 24,11 & 0,748 & 0,252 \\
$5,0 \times 10^{-6}$ & 0,52 & 0,93 & 54,36 & 42,05 & 0,564 & 0,436 \\
$6,0 \times 10^{-6}$ & 0,58 & 1,03 & 72,40 & 23,24 & 0,757 & 0,243 \\
\hline
\end{tabular}

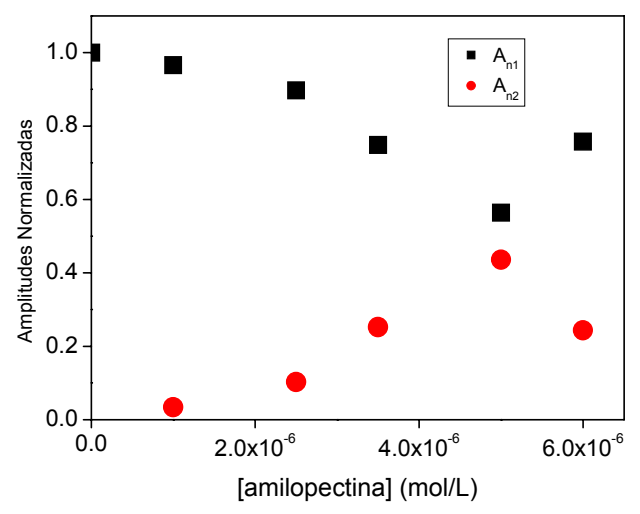

FIGURA 32. Relação entre as amplitudes dos componentes do tempo de vida da xantona em função da concentração da amilopectina.

Tentou-se analisar os componentes do tempo de vida da xantona (Xt) na presença de amilopectina $\left(\mathrm{Xt}_{\mathrm{p}}\right)$ e na fase aquosa $\left(\mathrm{Xt}_{\mathrm{aq}}\right)$ de acordo com o modelo adaptado de Noronha et al. 2004: 
Capítulo 5

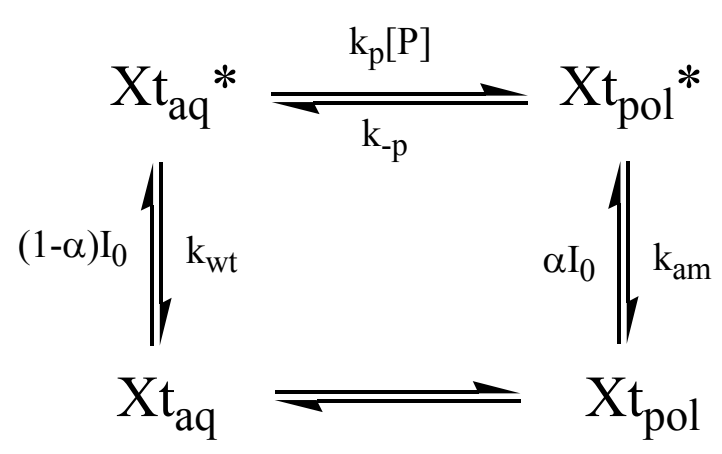

FIGURA 33. Esquema utilizado na análise do tempo de vida da xantona na presença de amilopectina e na fase aquosa.

Em outras palavras, a sonda fotofísica pode particionar-se tanto no estado fundamental $\left(\mathrm{Xt}_{\mathrm{aq}}\right.$ e $\left.\mathrm{Xt}_{\mathrm{pol}}\right)$ como no estado excitado singlete $\left(\mathrm{Xt}_{\mathrm{aq}}{ }^{*} \mathrm{e} \mathrm{Xt}_{\mathrm{pol}}{ }^{*}\right)$, entre os ambientes da solução aquosa e no interior do polímero, respectivamente. Os componentes de tempo de vida determinados possuem inclusos o valor do tempo de vida da xantona presente na fração de amilopectina $\left(1 / \mathrm{k}_{\mathrm{am}}\right)$ que a contém $(\alpha)$, enquanto o restante da sonda permanece em solução aquosa $\left(1 / k_{\mathrm{wt}}\right)$.

A solução matemática prevê que a evolução no tempo da concentração de xantona presente em solução aquosa e na amilopectina, $\mathrm{Xt}_{\mathrm{aq}}{ }^{*}$ e $\mathrm{Xt}_{\mathrm{pol}}{ }^{*}$, respectivamente, obedecem à equação 11, onde $X$ e $Y$ representam a soma de todos os processos responsáveis pela desativação de $\mathrm{Xt}_{\mathrm{aq}}$ e $\mathrm{Xt}_{\text {pol }}$, equações 12 e 13 .

$$
\begin{gathered}
\frac{d}{d t}\left[\begin{array}{c}
X t_{a q}^{*} \\
X t_{p}^{*}
\end{array}\right]=\left[\begin{array}{cc}
-X & k_{-p} \\
k_{p}[P] & -Y
\end{array}\right] \times\left[\begin{array}{c}
X t_{a q}^{*} \\
X t_{p}^{*}
\end{array}\right] \\
X=\mathrm{k}_{\mathrm{wt}}+\mathrm{k}_{\mathrm{p}}[\mathrm{P}] \\
\mathrm{Y}=\mathrm{k}_{-\mathrm{p}}+\mathrm{k}_{\mathrm{am}}
\end{gathered}
$$

Avalia-se que os decaimentos de fluorescência serão uma soma de duas Avalia-se que os decaimentos de fluorescência serão uma soma de duas exponenciais como descritas pelas equações 14 e 15, onde o recíproco dos tempos de decaimento mais curto $\left(\lambda_{2}=1 / \tau_{2}\right)$ e mais longo $\left(\lambda_{1}=1 / \tau_{1}\right)$ estão relacionadas com as constantes de velocidades representadas no esquema acima pela equação 16. 
Capítulo 5

$$
\begin{gathered}
I_{X t a q}(t)=a_{11} e^{-\lambda_{1} t}+a_{12} e^{-\lambda_{2} t} \\
I_{X t_{p}}(t)=a_{21} e^{-\lambda_{1} t}+a_{22} e^{-\lambda_{2} t} \\
\lambda_{2,1}=\frac{X+Y \pm\left((X-Y)^{2}+4 k_{p}[P] k_{-p}\right)^{1 / 2}}{2}
\end{gathered}
$$

A condição inicial $(t=0)$ :

$$
\begin{aligned}
& a_{11}+a_{12}=1-\alpha \\
& a_{21}+a_{22}=\alpha \\
& \alpha=\frac{k_{p}[P]}{k_{-p}+k_{p}[P]}
\end{aligned}
$$

As constantes pré-exponenciais $a_{11}, a_{12}, a_{21}$ e $a_{22}$ são expressas como funções das constantes de velocidade $k_{w t}, k_{p}[P], k_{-p}$ e $k_{a m}$, como descrito em Noronha et al. 2004.

Quando a xantona presente em solução aquosa e dentro do polímero possuem constantes de velocidade radioativas idênticas e frações idênticas de luz emitidas no comprimento de onda de emissão da medida, os coeficientes pré-exponenciais observados experimentalmente $A_{1}$ e $A_{2}$ são a soma dos pré-exponenciais individuais dos decaimentos de fluorescência $X t_{a q}$ e $X t_{p}$ (equações 20 e 21) e estão relacionadas com as constantes cinéticas pelas equações 22 e 23.

$$
\begin{aligned}
& A_{1}=a_{11}+a_{21} \\
& A_{2}=a_{21}+a_{22} \\
& A_{1}=\frac{(1-\alpha)\left(X-\lambda_{2}-k_{p}[P]\right)-\alpha\left(X-\lambda_{1}+k_{-p}\right)}{\lambda_{1}-\lambda_{2}}
\end{aligned}
$$


Capítulo 5

$$
A_{2}=\frac{\alpha\left(X-\lambda_{2}-k_{-p}\right)-(1-\alpha)\left(X-\lambda_{1}+k_{p}[P]\right)}{\lambda_{1}-\lambda_{2}}
$$

Assim, foram atribuídos valores para $k_{w t}, k_{p}[P], k_{-p}$ e $k_{a m}$ e calculados através das equações 22 e 23 para simularem o comportamento dos valores dos coeficientes pré-exponenciais determinados experimentalmente, as amplitudes normalizadas.

O melhor ajuste obtido foi com os valores descritos na TABELA 11 Estes valores foram avaliados através da inspeção visual do gráfico da FIGURA 34, onde as linhas contínua ou pontilhada ilustram o melhor comportamento dos valores de coeficientes pré-exponenciais calculados em relação aos valores experimentais. Os valores também foram ajustados globalmente através de uma planilha excel, onde se calculou o menor erro entre os valores determinados na TABELA 11 com a relação entre amplitudes calculadas e experimentais.

TABELA 11. Valores determinados de acordo com o modelo descrito em Noronha et al. 2004, para análise das amplitudes dos tempos de vida da xantona na presença de concentração variável de amilopectina.

\begin{tabular}{ll}
\hline $\mathrm{k}_{\mathrm{p}}$ & $1,66 \times 10^{29}$ \\
$\mathrm{k}_{-\mathrm{p}}$ & $7,76 \times 10^{7}$ \\
$\mathrm{k}_{\mathrm{wt}}$ & $1,59 \times 10^{9}$ \\
$\mathrm{k}_{\mathrm{am}}$ & $6,57 \times 10^{8}$ \\
\hline
\end{tabular}




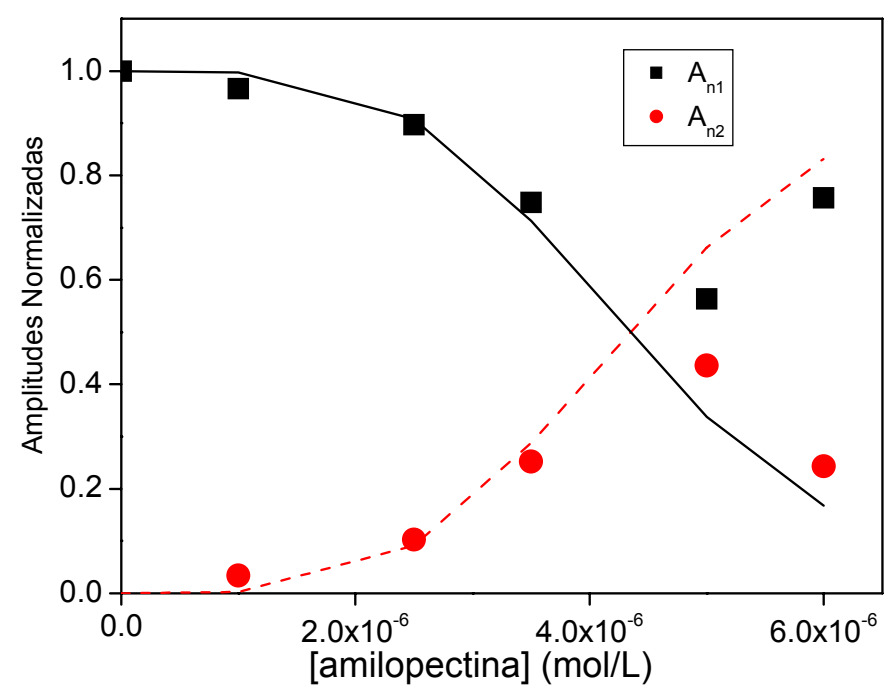

FIGURA 34. Ajuste de acordo com o modelo para descrição das amplitudes normalizadas e determinação das constantes de velocidade de desativação do estado excitado singlete da xantona presente em soluções de amilopectina (linha contínua ou pontilhada, valores calculados frente aos dados experimentais $\boldsymbol{\square}, 0$ ).

Observou-se que o valor da constante de velocidade do decaimento de fluorescência da xantona em água $\left(k_{w t}=1,59 \times 10^{9} \mathrm{~s}^{-1}\right)$ está bem próximo do determinado experimentalmente $\left(1,47 \times 10^{9} \mathrm{~s}^{-1}\right)$. A constante de velocidade de desativação do estado excitado singlete da xantona em região interna do polímero é menor do que a desativação da sonda em solução aquosa $\left(6,57 \times 10^{8} \mathrm{~s}^{-1}\right)$, possivelmente devido a proteção que as cadeias ramificadas da amilopectina oferecem a xantona. A constante de velocidade de saída da xantona no estado excitado é da ordem de $7,76 \times 10^{7} \mathrm{~s}^{-1}$, inferior a da difusão de solutos em soluções aquosas da ordem de $1 \times 10^{9} \mathrm{~s}^{-1}$ (MUROV, CARMICHAEL \& HUG, 1993). Novamente tendo como possibilidade a proteção que o esqueleto polimérico da amilopectina oferece à sonda para sua saída ao seio da solução aquosa. Porém, o valor da constante de velocidade da entrada da sonda ao ambiente polimérico encontra-se demasiada elevada, $1,66 \times 10^{29} \mathrm{~s}^{-1}$, não possuindo significado físico apropriado.

Além disso, o gráfico mostra a tendência do comportamento esperado destes coeficientes em relação aos pontos experimentais. Verifica-se que os pontos experimentais divergem em concentrações mais elevadas de amilopectina, sendo esperado que os coeficientes aumentassem ou diminuíssem de maneira 
Capítulo 5

proporcional a quantidade de polímero. Uma possível explicação para este fato pode ser devido a insolubilidade da amilopectina em altas concentrações de polímero.

Uma outra observação importante a ser dita é que para a determinação das curvas do gráfico e das constantes de velocidade acima mencionadas, foi necessário atribuir uma concentração de amilopectina muito inferior a utilizada experimentalmente. A ordem de concentração utilizada na realidade foi de $10^{-6}$ $\mathrm{mol} / \mathrm{L}$, ao passo que para a determinação dos valores analisados estimou-se uma concentração da ordem de $10^{-20} \mathrm{~mol} / \mathrm{L}$.

Outro fator que contribui para esta justificativa é o fato que a análise global contendo os decaimentos da xantona em todas as concentrações de amilopectina pode ter um bom ajuste, mostrando um desvio das amplitudes em concentrações superiores de amilopectina. O espectro de fluorescência em estado estacionário também exibiu que a fluorescência da xantona não se altera significativamente com a concentração deste polímero. Conclui-se, portanto, que o estado fundamental da xantona encontra-se preferencialmente no seio da solução aquosa, ao invés no interior ou próximo ao esqueleto polimérico.

\subsubsection{MEDIDAS DO ESTADO EXCITADO TRIPLETE DA XANTONA EM} SOLUÇÕES AQUOSAS DE AMILOPECTINA.

O estado excitado triplete $\pi, \pi^{*}$ da xantona não é reativo a abstração do átomo de hidrogênio na maioria dos solventes, é mais polar do que o estado fundamental e a posição do máximo no espectro de absorção do triplete-triplete desloca-se em solventes de diferentes polaridades (EVANS et al., 1999). Por exemplo, em tetracloreto de carbono, o máximo ocorre em $648 \mathrm{~nm}$, enquanto que em água, desloca-se para o azul, $580 \mathrm{~nm}$ (SCAIANO, 1980). O momento de dipolo do estado excitado triplete da xantona é maior do que o estado fundamental, provocando a sua relocalização em sistemas microheterogêneos que possua a presença de diferença de polaridade. Por este motivo, na literatura (BARRA, BOHNE \& SCAIANO, 1990; OKANO et al., 2001), a xantona já foi extensamente aplicada para determinar as velocidades de entrada e saída por método direto em ciclodextrinas. 
Capítulo 5

Nesta Tese de Doutorado, tentou-se verificar a possibilidade de investigação das propriedades físico-químicas dos agregados formados pelo esqueleto polimérico da amilopectina utilizando o estado excitado triplete da xantona. Com esse propósito, utilizou-se o mesmo preparo de soluções para as medidas de fluorescência resolvida no tempo. Registraram-se espectros dos transientes formados após a excitação do laser em um equipamento de fotólise por pulso de laser, de diferentes concentrações de amilopectina e em diferentes escalas de tempo de aquisição. Comparou-se se houve um grande deslocamento no máximo registrado nestes espectros. Determinaram-se, também, o tempo de vida do estado excitado triplete em diferentes concentrações de amilopectina, em comprimento de onda fixo.

Se for verificado um grande deslocamento no máximo dos espectros de absorção T-T da xantona em diferentes escalas de tempo, em um tempo muito curto de aquisição a constante de velocidade que se determina experimentalmente $\left(\mathrm{k}_{\mathrm{obs}}\right)$ é uma função do equílibrio de entrada e saída da sonda nos agregados que tiverem diferença de polaridade em relação ao seio da solução (BOHNE, 2000).

$$
k_{\text {obs }}=k_{-}+k_{+}[\text {amilopectina }]
$$

onde $k_{+}$e $k_{-}$são as constantes de velocidade de entrada e saída da sonda nos agregados formados pela amilopectina em solução aquosa. A constante de equilíbrio do estado triplete, $K_{T}$ seria dada por:

$$
K_{T}=\frac{k_{+}}{k_{-}}
$$

Os resultados estão descritos a seguir. 
Capítulo 5

5.1.2.1. Espectros de absorção T-T da xantona presente em diferentes concentrações de amilopectina.
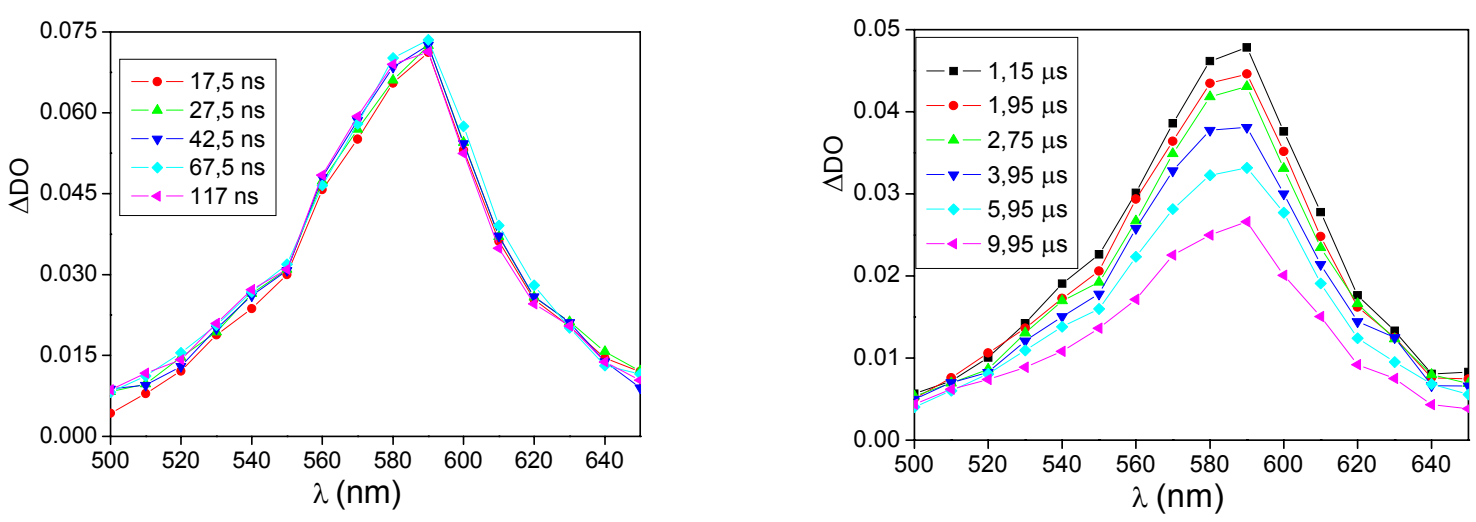

FIGURA 35. Espectro de absorção $T$ - $T$ da xantona em $0,1 \%$ amilopectina registrado em (A) 20 ns e (B) $2 \mu$ s por divisão.

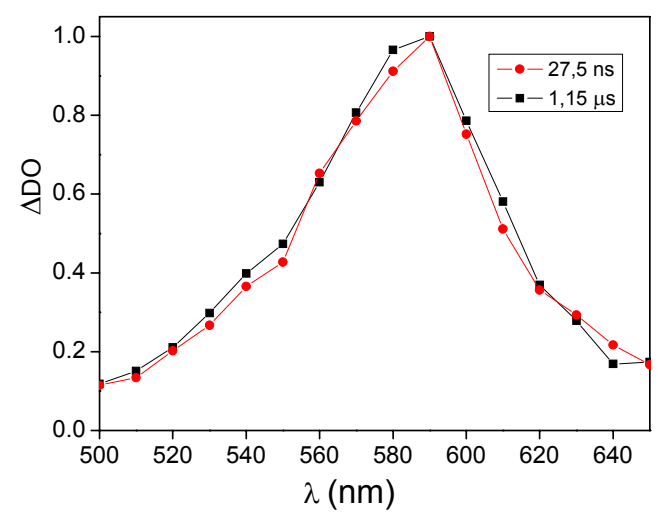

FIGURA 36. Espectro normalizado de absorção $T-T$ da xantona em $0,1 \%$ amilopectina registrado após (0) 27,5 ns e ( 1 ( $1,15 \mu$ s após a excitação do pulso de laser. 


\section{Capítulo 5}
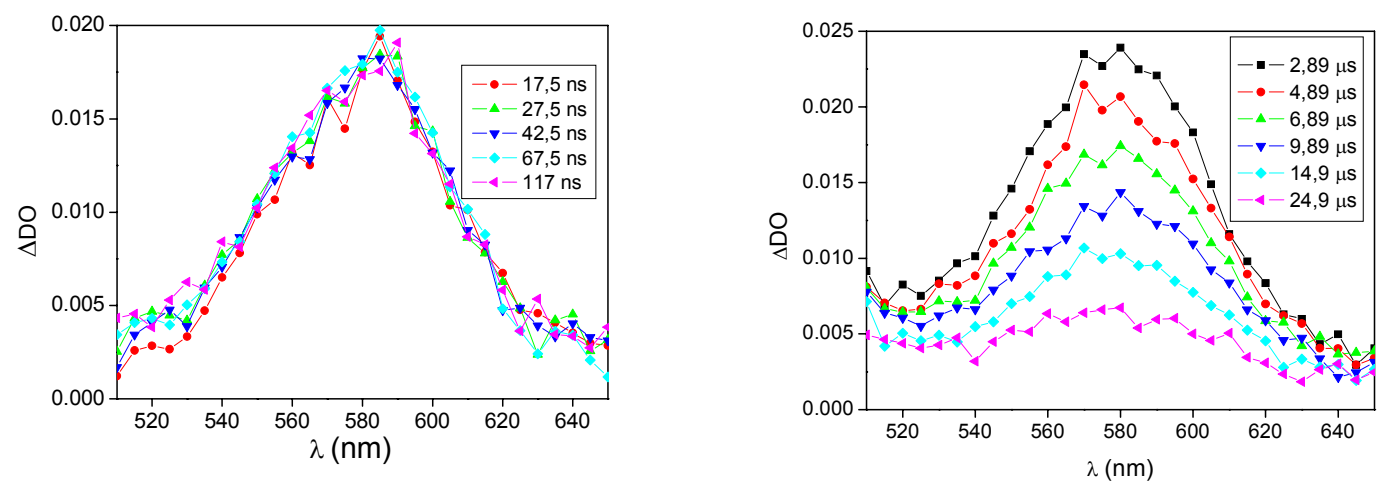

FIGURA 37. Espectro de absorção $T$-T da xantona em $0,5 \%$ amilopectina registrado em (A) 20 ns e (B) $5 \mu$ s por divisão.

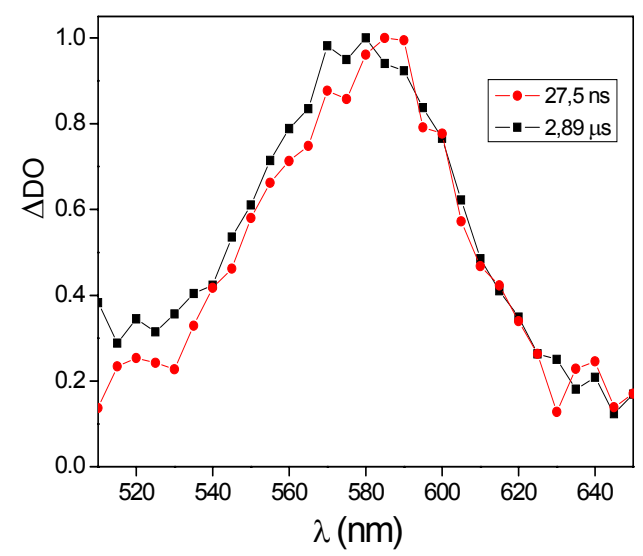

FIGURA 38. Espectro normalizado de absorção $T$ - $T$ da xantona em $0,5 \%$

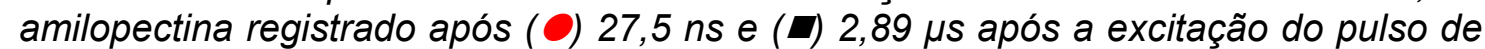
laser.
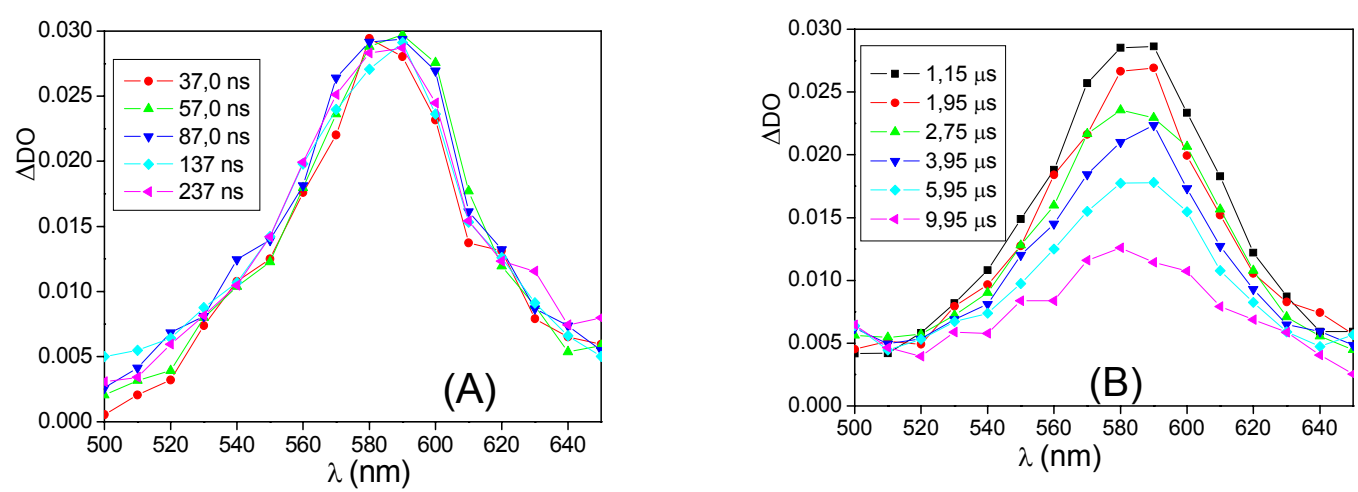

FIGURA 39. Espectro de absorção $T$-T da xantona em 1,0\% amilopectina registrado em (A) 50 ns e (B) $2 \mu$ s por divisão. 
Capítulo 5

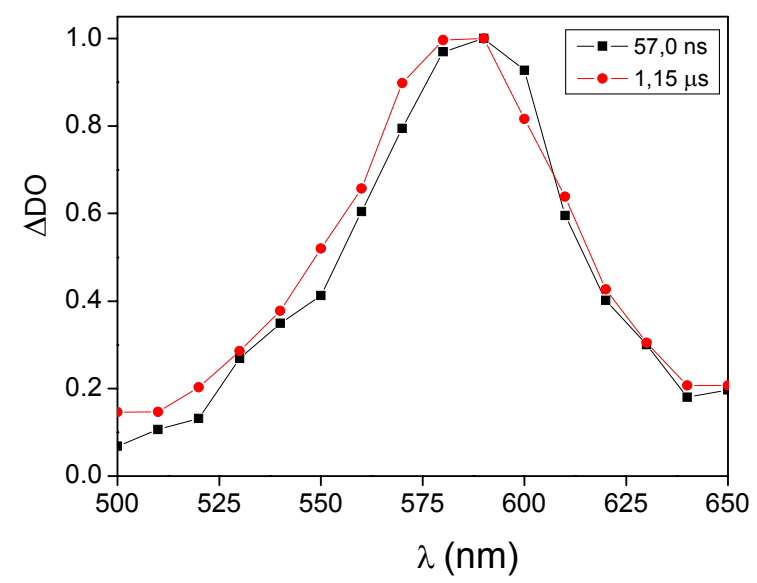

FIGURA 40. Espectro normalizado de absorção $T-T$ da xantona em 1,0\% amilopectina registrado após ( $\mathbf{\square}$ ) 57,0 ns e (O) 1,15 $\mu$ s após a excitação do pulso de laser.

Foram registrados espectros de absorção T-T da xantona presente em 0,$1 ; 0,5$ e $1,0 \%$ de amilopectina em uma escala de tempo de aquisição mais curto e longo (FIGURAS 35, 37 e 39). Como as FIGURAS 36, 38 e 40 evidenciam os espectros normalizados, verifica-se que não há deslocamento do máximo de absorção T-T da xantona nestas concentrações de amilopectina. A Figura 7 exibe a normalização o espectro dos transientes das soluções de xantona presente em diferentes concentrações de amilopectina, comparadas com o espectro normalizado da solução aquosa saturada de xantona.

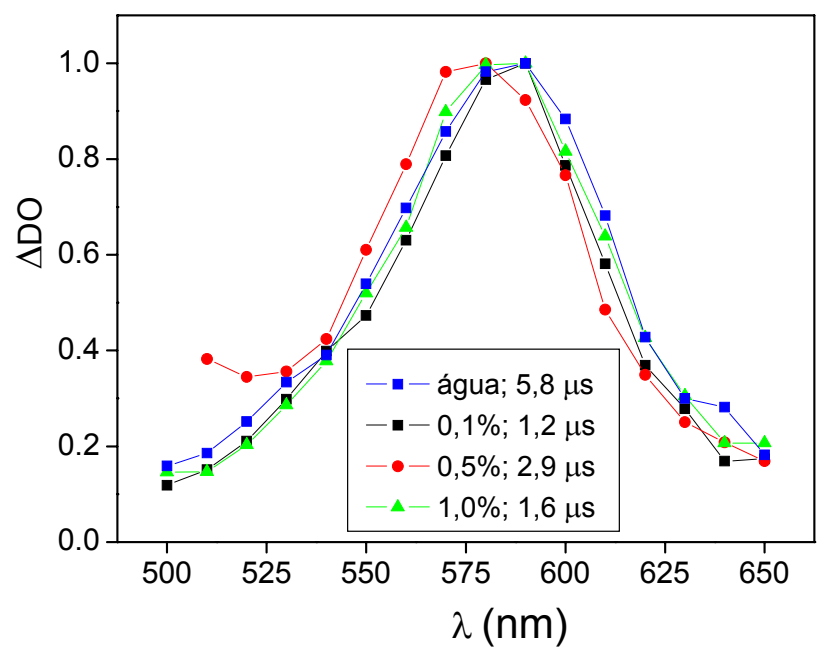

FIGURA 41. Espectro normalizado de absorção $T$ - $T$ da xantona em água ( $\boldsymbol{\square}, 5,8$ $\mu \mathrm{s})$ e em $0,1 \%(\boldsymbol{\Delta}, 1,15 \mu \mathrm{s}), 0,5 \%(0,2,89 \mu \mathrm{s})$ e $1,0 \%(\Lambda, 1,57 \mu \mathrm{s})$ de amilopectina após a excitação do pulso de laser. 
Capítulo 5

O tempo de vida do estado excitado triplete da xantona em água (EVANS et al.,

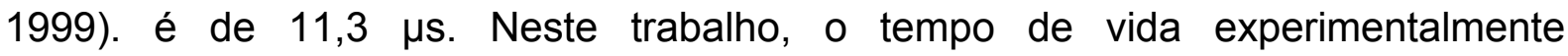
determinado para o estado triplete da xantona em água foi de 14,0 $\pm 0,6 \mu$ s. Como as medidas de fotólise por pulso de laser apresentam uma razão sinal/ ruído relativamente alto, pode-se considerar que o valor experimental do tempo de vida do estado triplete da xantona concorda com a literatura.

Por sua vez, foram registrados vários decaimentos cinéticos do estado excitado triplete da xantona nas várias concentrações de amilopectina em vários comprimentos de onda e em escalas de tempo distintas. Os valores determinados encontram-se discriminados na TABELA 12.

TABELA 12. Valor do tempo de vida do estado triplete da xantona na presença de concentração variável de amilopectina, a $580 \mathrm{~nm}$.

\begin{tabular}{cc}
\hline Amilopectina (\%) & $\tau(\boldsymbol{\mu s})$ \\
\hline 0,1 & $8,0 \pm 0,2$ \\
0,2 & $11,0 \pm 0,1$ \\
0,5 & $5,8 \pm 0,1$ \\
0,7 & $1,2 \pm 0,2$ \\
1,0 & $5,2 \pm 0,3$ \\
1,2 & $7,4 \pm 0,1$ \\
\hline
\end{tabular}

O tempo de vida do estado triplete da xantona em $0,7 \%$ de amilopectina é um valor muito baixo comparado com as demais concentrações. Isso pode ser devido a uma falha no degaseamento desta amostra. Infelizmente, a determinação deste valor não foi feita novamente.

Vale a pena observar que este tempo de vida, coletado a $580 \mathrm{~nm}$, máximo de absorção T-T, foi o mesmo registrado nos vários comprimentos de onda. Considerando que não há diferença entre os espectros, calculou-se a média destes valores como o tempo de vida da xantona no esqueleto de amilopectina como sendo de $7 \pm 2 \mu \mathrm{s}$. O valor estimado aproxima-se em ordem de grandeza ao publicado por Evans e colaboradores (1999) para a xantona em alcoóis lineares. 


\subsection{INTERAÇÃO DA XANTONA EM SOLUÇÕES AQUOSAS DE CARBOXIMETILCELULOSE.}

Devido impossibilidade de obtenção de dados mais consistentes sobre a interação entre a xantona e amilopectina, através de medidas de fluorescência resolvida no tempo na escala de picossegundos e de fotólise por pulso de laser, deciciu-se por investigar um sistema já em estudo no nosso grupo de pesquisa. $O$ sistema formado pela carboximetilcelulose (CMC) e xantona.

A carboximetilcelulose (viscosidade ultrabaixa 10-55 cPs, da Aldrich) utilizada possui um peso molecular de $52324,1 \mathrm{~g} / \mathrm{mol}$, determinado por espalhamento estático de luz (TOUSO, 2003) e um grau de substituição de 0,37, obtido por titulação condutimétrica(TOUSO, 2003; CAPITANI, PORROB \& SEGREA, 2000). Medidas anteriores (TOUSO, 2003) de fluorescência no estado estacionário, FIGURA 42, exibiram claramente a possibilidade de protonação da xantona na presença de concentração variável de CMC.

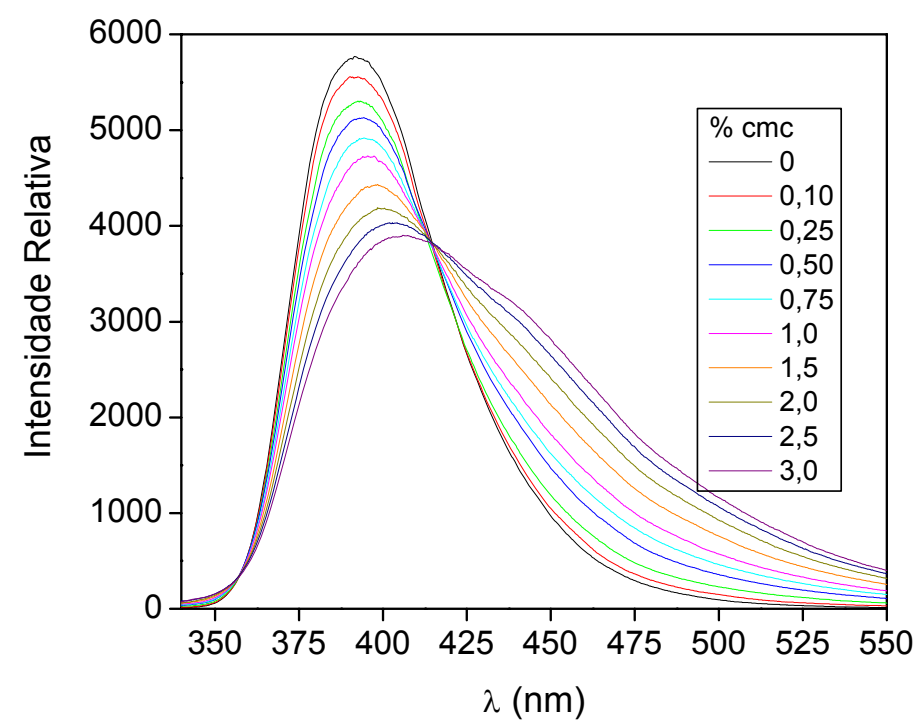

FIGURA 42. Espectros de fluorescência da xantona ${ }^{1}$ em concentração variável de CMC, $\lambda_{\text {exc. }}=320 \mathrm{~nm}$.

Os espectros da FIGURA 42 estão de acordo com o estudo de Ireland e Wyatt (1972). Em soluções aquosas, a molécula neutra da xantona fluoresce fracamente 
Capítulo 5

com emissão máxima em $395 \mathrm{~nm}$, enquanto a xantona protonada fluoresce com maior intensidade, com máximo em $456 \mathrm{~nm}$. Assim, teríamos os seguintes equilíbrios de partição da xantona na presença de CMC.

$$
\mathrm{Xt}\left(\mathrm{CO}_{2}^{-}\right) \rightleftharpoons \mathrm{Xt} \text { (água) } \rightleftharpoons \mathrm{Xt}\left(\mathrm{CO}_{2} \mathrm{H}\right)
$$

A xantona da fase aquosa poderia interagir com o esqueleto polimérico da CMC, quer seja com as unidades carboxílicas protonadas ou não.

Portanto, registraram-se os decaimentos cinéticos da xantona em soluções aquosas de concentração variável de CMC (0 a 3\%), coletando-se simultaneamente dois comprimentos de onda distintos, 390 e $475 \mathrm{~nm}$. A análise para cada concentração foi feita considerando globalmente os tempos de vida nestes dois comprimentos de onda.

Verificou-se que os melhores ajustes dos tempos de vida da xantona eram formados por triexponenciais (TABELA 13). Entretanto, em $390 \mathrm{~nm}$, a contribuição do tempo mais longo é muito pequena, ao passo que, em $475 \mathrm{~nm}$, na menor escala de tempo por canal utilizada, 3 ps/canal, o decaimento não foi coletado até o fim. Por este motivo, medidas foram refeitas com uma resolução de 4 ps/canal. 

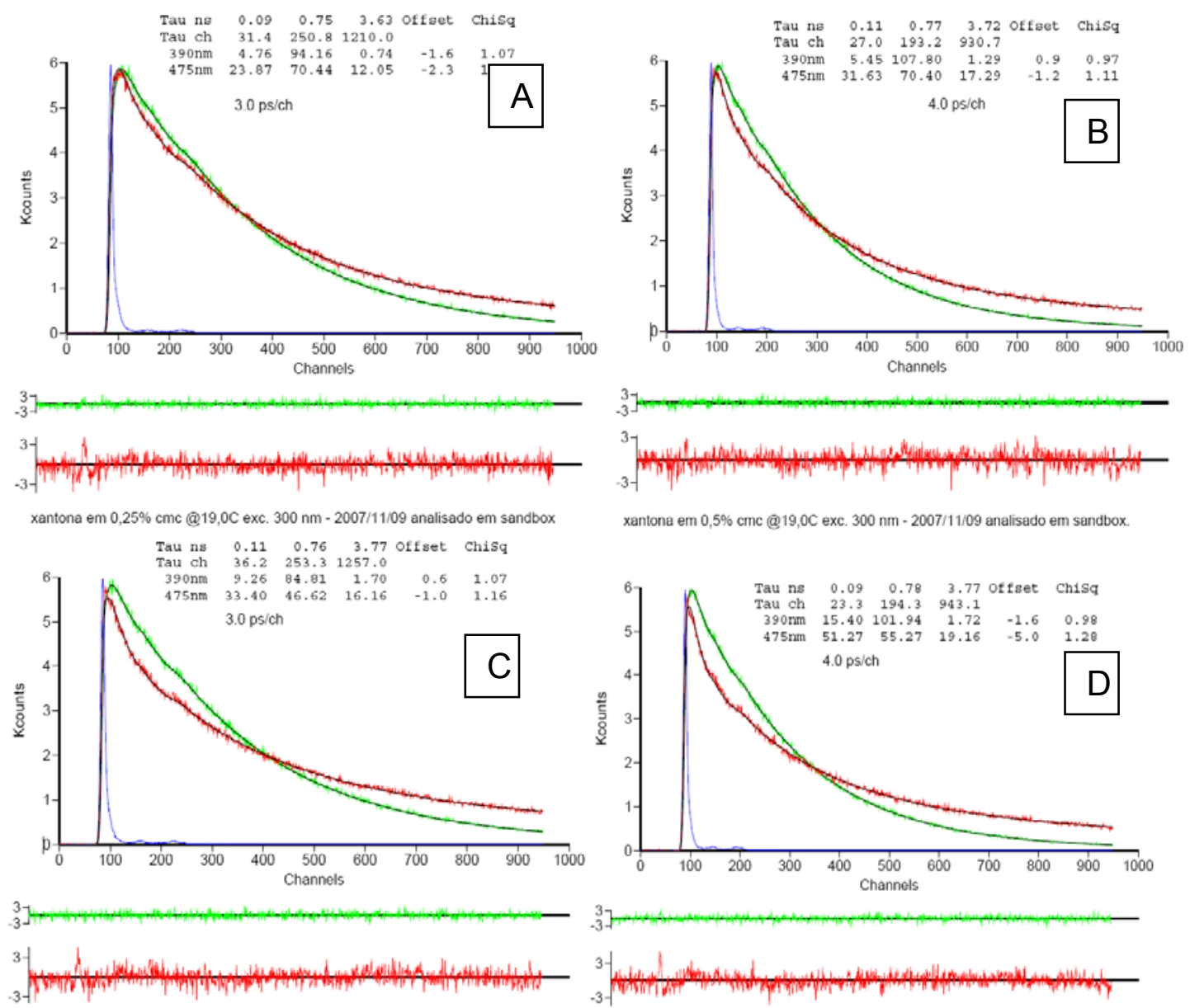

xantona em 1,0\% cmc @19,0C exc. $300 \mathrm{~nm}$ - 2007/11/09 analisado em sandbox.
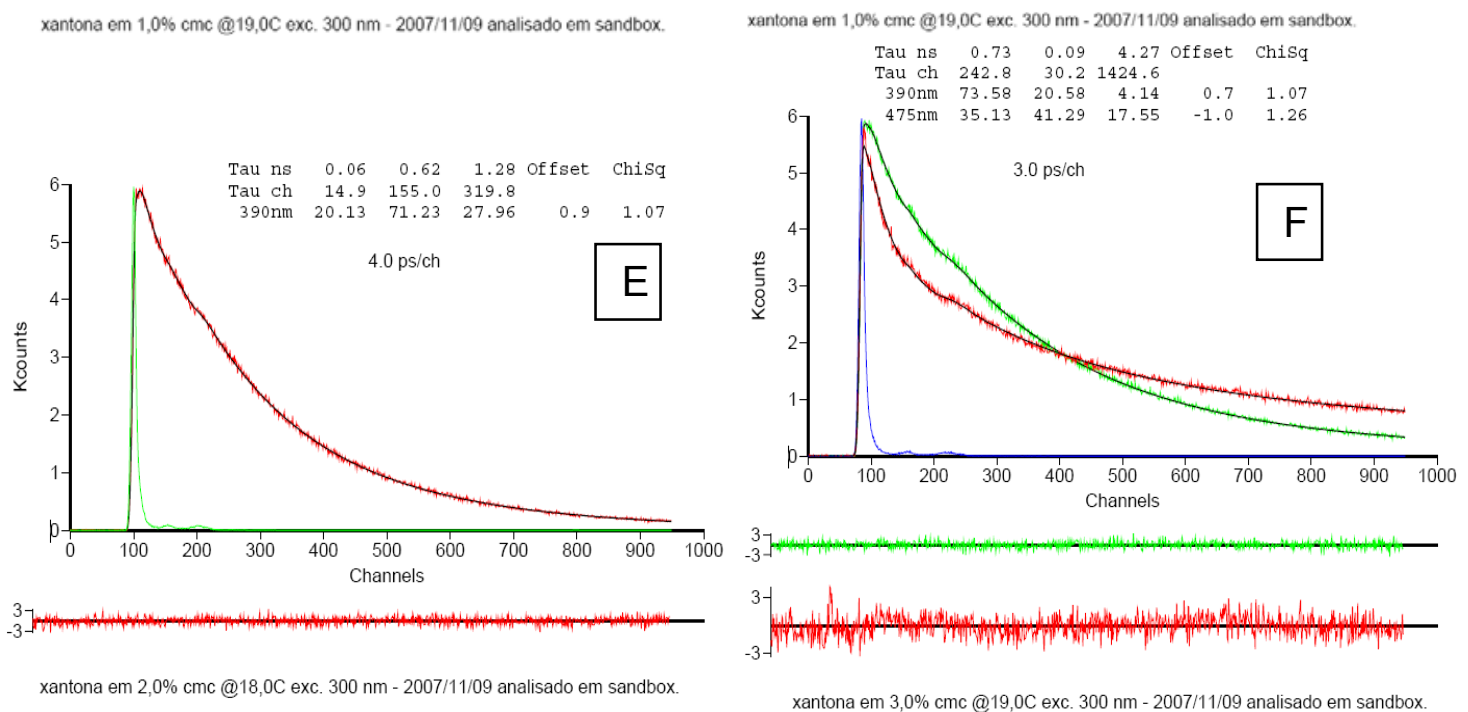
$\left.\begin{array}{r}3 \\ -3\end{array}\right]$

xantona em 2,0\% cmc @18,0C exc. 300 nm - 2007/11/09 analisado em sandbox.

FIGURA 43. Decaimentos de fluorescência da xantona na ausência e presença de diferentes concentrações de CMC (A) em água, (B) 0,2; (C) 0,5; (D) 0,7; (E) 1,0 e (F) $1,2 \%$ de CMC. 
Capítulo 5
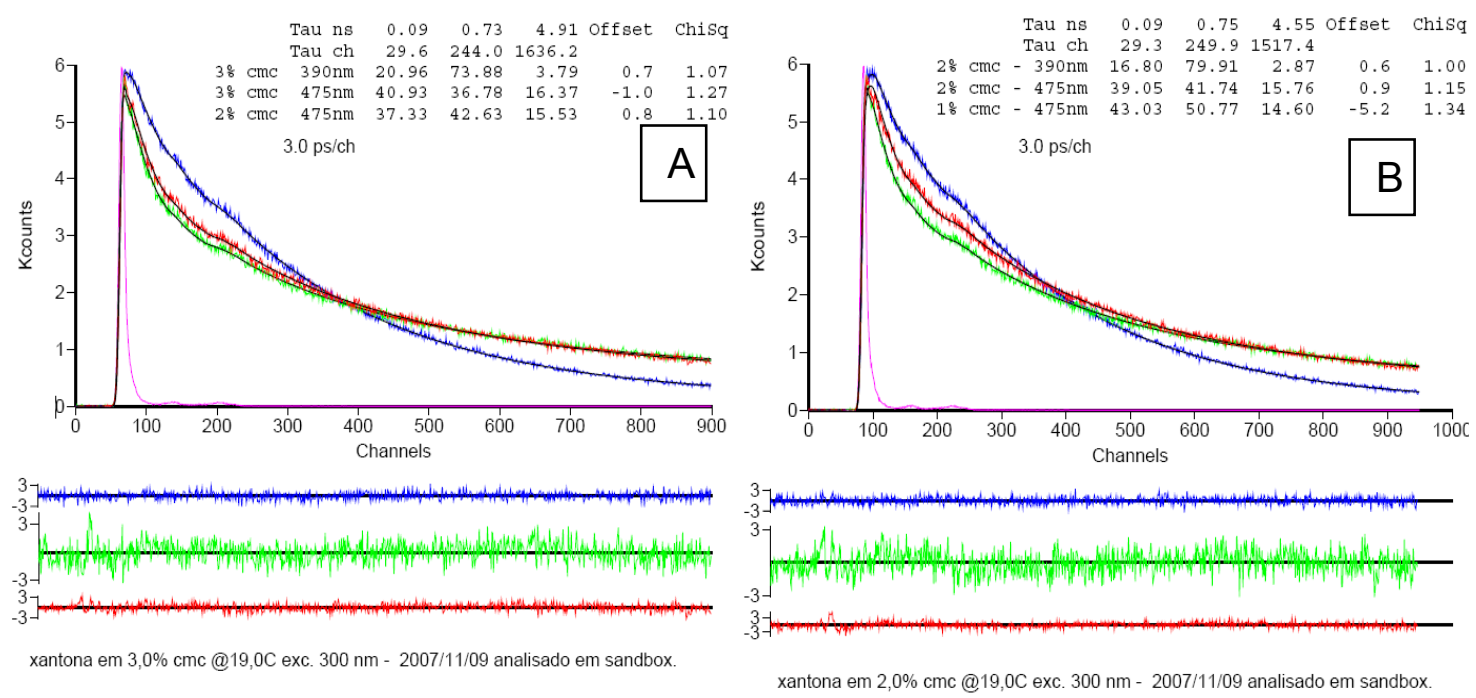

FIGURA 44. Decaimentos de fluorescência da xantona na ausência e presença de diferentes concentrações de CMC (A) $3 \%$ de $C M C$, (B) $2 \%$ de CMC.

Deste modo, iniciou-se a análise de todos os decaimentos com as medidas com a resolução de 4 ps/ canal, obtendo-se o tempo de vida mais longo. Este tempo de vida foi fixado para os decaimentos com resolução de 3 ps/ canal, para determinação dos tempos de vida menores. Nas concentrações de CMC na qual não foram feitas medidas com 4 ps/ canal, optou-se por analisar as medidas de 3 ps/ canal em conjunto com a concentração anterior, em $475 \mathrm{~nm}$, com o propósito de aumentar a contribuição do tempo mais longo. Dados obtidos de tempo de vida estão discriminados na TABELA 13. 
Capítulo 5

Análise Global - Xantona em carboximetil celulose (4,0 ps/ch)

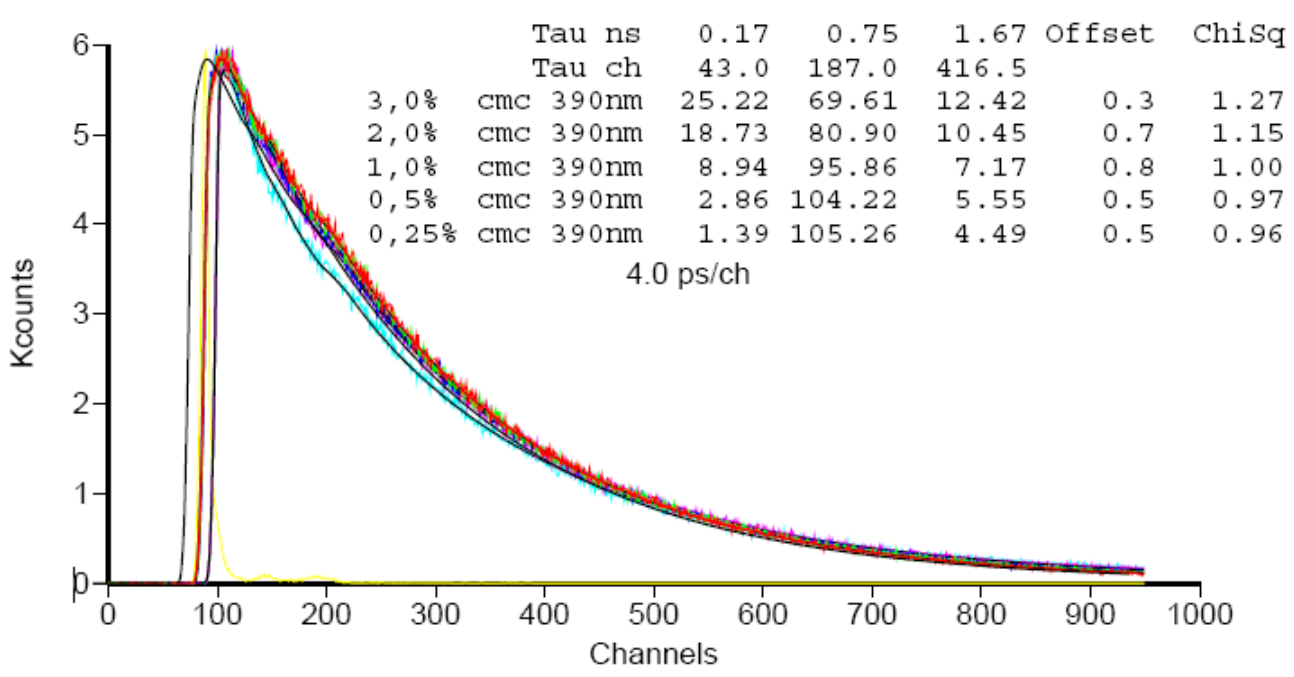

FIGURA 45. Análise global da xantona em na presença de concentração variável de carboximetil celulose.

TABELA 13. Tempos de vida da xantona presente em concentração vairável de CMC.

\begin{tabular}{ccccc}
\hline \% CMC & [monômero] mol/L & $\tau_{\mathbf{1}}$ (ns) & $\tau_{\mathbf{2}}$ (ns) & $\tau_{\mathbf{3}}$ (ns) \\
\hline 0 & 0 & & 0,68 & \\
0,25 & 0,013 & 0,090 & 0,75 & 3,63 \\
0,5 & 0,027 & 0,080 & 0,75 & 3,72 \\
1,0 & 0,053 & 0,11 & 0,76 & 3,77 \\
2,0 & 0,106 & 0,080 & 0,75 & 4,50 \\
3,0 & 0,159 & 0,090 & 0,73 & 4,91 \\
\hline
\end{tabular}


Capítulo 5

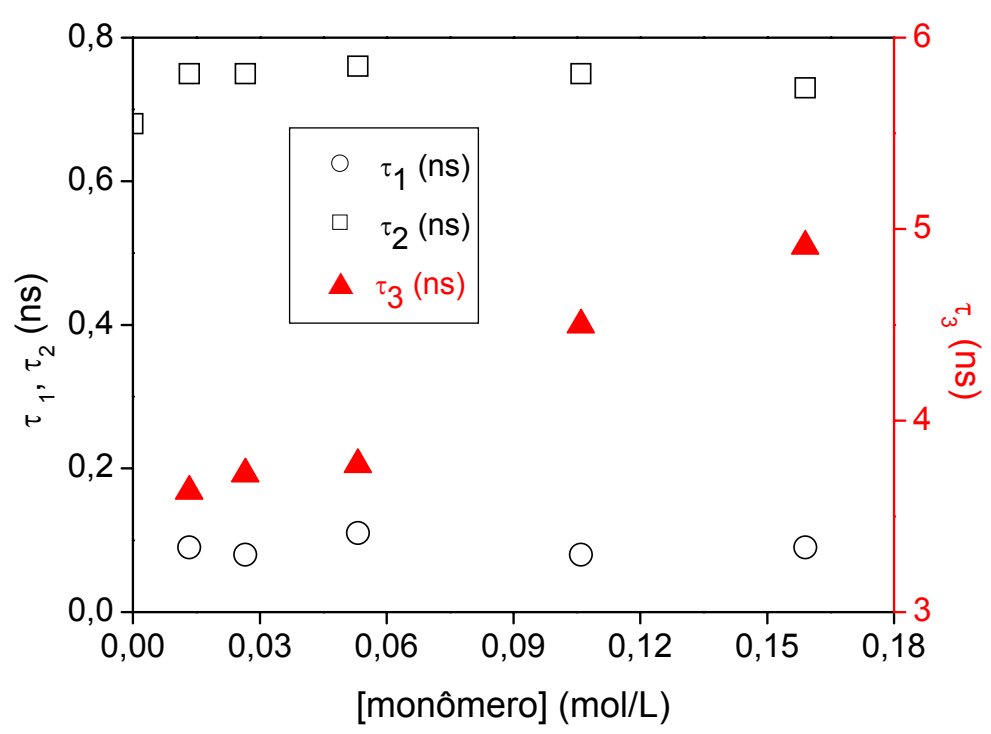

FIGURA 46. Gráfico do tempo de vida da xantona experimentalmente determinado na presença de concentração variável de monômeros de CMC.

Pela FIGURA 45, observa-se que há três tempos de vida muito distintos. Dois extremamente pequenos que não variam significativamente com a concentração do polímero. Por outro lado, um tempo de vida mais longo apresenta uma relação direta de proporcionalidade com a concentração polimérica.

A TABELA 14 mostra os valores normalizados das amplitudes para cada comprimento de onda investigado. 
Capítulo 5

TABELA 14. Valores normalizados das amplitudes determinadas para cada comprimento de onda analisado

$390 \mathrm{~nm} \quad 475 \mathrm{~nm}$

\begin{tabular}{cccccccc}
\cline { 3 - 7 } \% CMC & [monômero] mol/L & $\mathrm{A}_{1}$ & $\mathrm{~A}_{2}$ & $\mathrm{~A}_{3}$ & $\mathrm{~A}_{1}$ & $\mathrm{~A}_{2}$ & $\mathrm{~A}_{3}$ \\
\hline 0,25 & 0,013 & 0,0478 & 0,945 & 0,00743 & 0,224 & 0,662 & 0,113 \\
0,5 & 0,027 & 0,0518 & 0,935 & 0,0133 & 0,325 & 0,546 & 0,130 \\
1,0 & 0,053 & 0,0967 & 0,886 & 0,0178 & 0,347 & 0,485 & 0,168 \\
2,0 & 0,106 & 0,220 & 0,754 & 0,0267 & 0,429 & 0,415 & 0,156 \\
3,0 & 0,159 & 0,213 & 0,749 & 0,0384 & 0,435 & 0,391 & 0,174
\end{tabular}
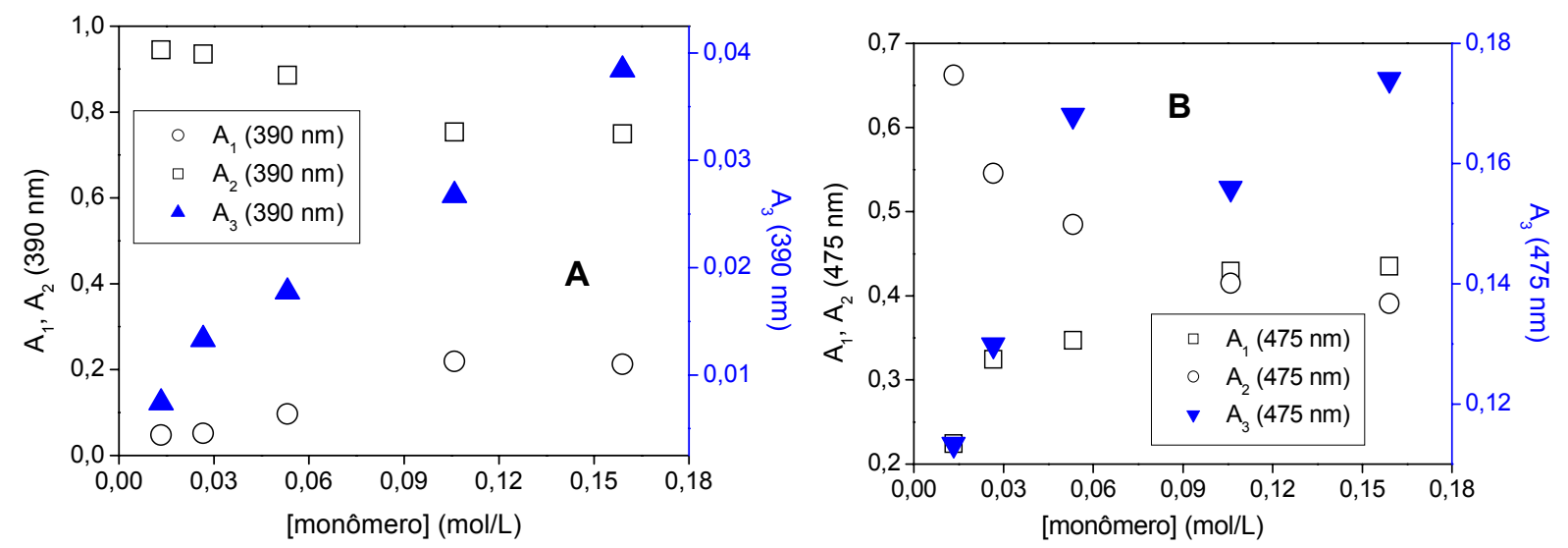

FIGURA 47. Gráfico das amplitudes normalizadas em função da concentração do monômero da CMC. (A) $390 \mathrm{~nm}$ e (B) $475 \mathrm{~nm}$.

Pelos gráficos da FIGURA 47, observa-se que as amplitudes do segundo tempo de vida $\left(A_{2}\right)$ diminui enquanto as amplitudes dos outros dois tempos de vida, $\mathrm{T}_{1}$ e $\mathrm{T}_{3}$, aumentam com a concentração polimérica.

Uma interpretação para estes dados é que a xantona inicialmente solubilizada em solução aquosa, possui um tempo de vida de 680 ps (valor da literatura (MURPHY et al., 1999) é $750 \pm 50$ ps). Com a adição da CMC a xantona particionase em sítios protonados e não protonados do esqueleto polimérico. Os primeiros sítios possuem um tempo de vida mais longo, de 3,6 a 4,9 ns, que aumentam com a concentração da CMC. O menor tempo de vida relaciona-se com os sítios desprotonados, mas próximos ou no interior polimérico. O tempo de vida da ordem 
Capítulo 5

de 730 a 760 ps correlaciona-se com o valor do tempo de vida da xantona ainda presente no seio da solução aquosa. Conforme se aumenta a concentração da CMC, a amplitude deste tempo de vida $\left(\tau_{2}\right)$ cresce à suas expensas.

Uma segunda forma de análise foi realizada levando-se em consideração o método de entropia máxima (MEM) (VALEUR, 2001; LIVESEY \& BROCHON, 1987). Para um decaimento multiexponencial com $n$ componentes cujas amplitudes fracionais são $\alpha_{i}$, a resposta do pulso- $\delta$ é:

$$
I(t)=\sum_{i=1}^{n} \alpha_{i} \exp \left(-t / \tau_{i}\right)
$$

ou, para uma distribuição de tempos de decaimentos:

$$
I(t)=\int \alpha(t) \exp (-t / \tau) d \tau
$$

O problema existe para determinar o espectro do tempo de decaimento $\alpha(\tau)$ de dados de fluorescência resolvida no tempo. $\alpha(\tau)$ aparece como o inverso da transformada de Laplace do decaimento de fluorescência deconvoluído pelo pulso de luz. Entretanto, invertendo a transformada de Laplace não é muito apropriado. Consequentemente, pequenos erros inevitáveis dentro da medida do decaimento de fluorescência ou do perfil do pulso do instrumento pode gerar muitas grandes mudanças na reconstrução de $\alpha(\tau)$, ou seja, uma quantidade muito alta soluções possíveis. Dentro das soluções que ajustam perfeitamente bem o decaimento experimental baseado em testes estatísticos (principalmente, valores de $\chi^{2}$, peso dos resíduos e funções de auto-correlação), algumas podem ser rejeitadas quando contém características não físicas. O conjunto restante de soluções é chamado de conjunto possível do qual teremos que escolher um membro.

A escolha da solução preferida dentro do conjunto de possíveis soluções pode ser feita maximizando algumas funções $F[\alpha(\tau)]$ do espectro que introduz os menores artefatos à distribuição. Utilizando a entropia $S$ de Shannon-Jaynes, tem-se a solução mínima de correlações. Todas as demais funções de maximizações (ou regularizações) introduzem correlações desnecessárias pelos dados. A função $S$ é definida como: 
Capítulo 5

$$
S=\int_{0}^{\infty}\left[\alpha(t)-m(t)-\alpha(t) \log \frac{\alpha(t)}{m(t)}\right] d \tau
$$

onde $\mathrm{m}$ é modelo que engloba nosso conhecimento prévio sobre o sistema. Tem sido demonstrado que se não há nenhum conhecimento prévio dos valores das amplitudes $\alpha$, todas possuem uma probabilidade igual a priori e $m$ uma distribuição plana $\left(m_{i}=\right.$ constante).

Empregando esta análise, obtiveram-se os gráficos da Figura 48, que mostra distribuição do tempo das amplitudes em função do tempo de vida. Como o sistema investigado são polímeros, a FIGURA 48A retrata muito bem que conforme se aumenta a concentração de $\mathrm{CMC}$, há uma distribuição muito maior de tempo de vida, devido aos vários sítios possíveis de interação entre a xantona e o polímero. 0 contraste fica por conta da Figura 48B que mostra o mesmo tratamento para a amilopectina. Neste último polímero, a distribuição de tempo de vida e amplitudes não varia com a concentração do polímero.
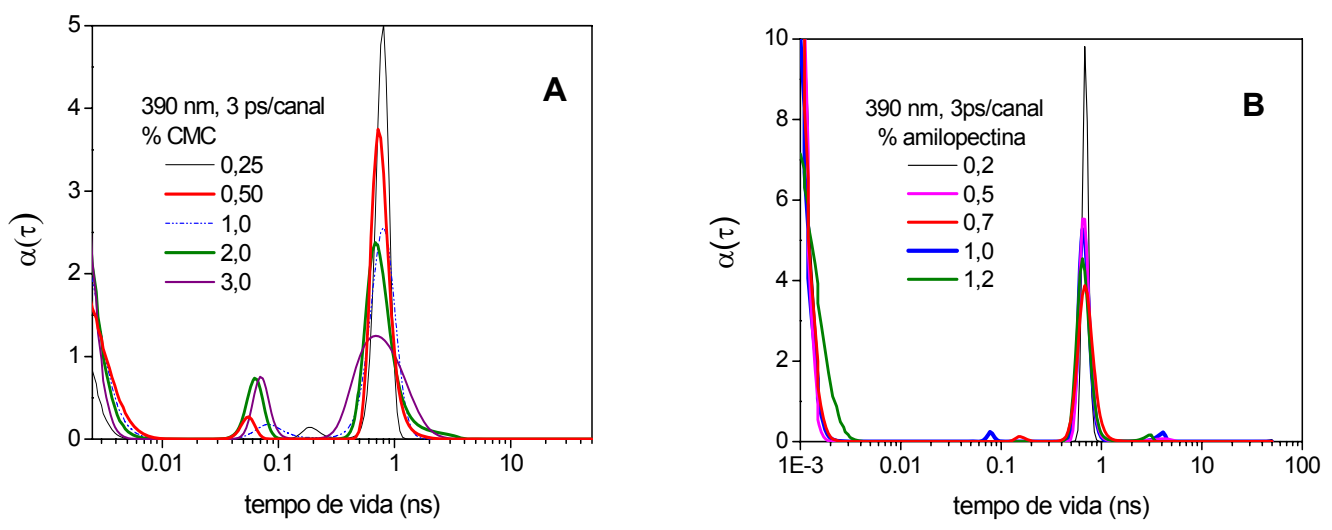

FIGURA 48. Análise dos decaimentos de fluorescência utilizando o método de entropia máxima (A) CMC e (B) amilopectina. 
Capítulo 6

\section{CAPÍTULO 6}

\subsection{A ESTABILIZAÇÃO DO CÁTION FLAVÍLIO}

Os cátions flavílio apresentam uma estabilidade fortemente dependente das condições do meio. Sua estabilização pelo meio de dispersão permitirá aplicações diversas, uma vez que as atividades biológicas e químicas decorrentes de uma das suas estruturas participantes do equilíbrio químico serão preservadas.

Neste trabalho, iniciamos o estudo da estabilização do cátion flavílio 2fenilbenzopirílio em diversos solventes orgânicos. Os solventes escolhidos foram separados em grupos com características específicas. Álcoois de cadeia simples e etilenoglicol (ETG) que são solventes com elevada viscosidade e com características semelhantes aos biopolímeros. Solventes com polaridade de intermediária a baixa. Um solvente com estrutura aromática (tolueno), o que permite obter informações para posteriores estudos de copigmentação. Um éter (tetrahidrofurano-THF) permitindo uma comparação sobre o efeito da ligação de hidrogênio dos álcoois sobre a estabilização das espécies. Ao final, verificamos o equilíbrio de estabilização do cátion flavílio nos biopolímeros: amilopectina, carboximetilcelulose e 2hidroxietilamido.

Em todos os casos, buscamos proteger as amostras da presença de luz. A metodologia adotada por nosso grupo durante os estudos de estabilidade envolveu a 
Capítulo 6

preservação da espécie em questão por meio da proteção dos frascos, que contêm as soluções, com papel alumínio sob refrigeração. Após retirar uma alíquota da solução preparada, guardávamos a mesma na geladeira para evitar sua degradação. Ao final dos experimentos a alíquota era descartada. Palamidis e Markakis (1975) observaram que a presença de luz acelerou a destruição das antocianinas em bebidas carbonatadas, coloridas com antocianinas extraídas da polpa da uva. Eles ainda reportam que o tempo de meia-vida das antocianinas a $20^{\circ} \mathrm{C}$ no escuro foi de 416 dias, diminuindo para 197 dias quando as bebidas foram expostas à luz ambiente nas mesmas condições de temperatura.

A estabilização realizada nos solventes orgânicos testados, inicialmente, não envolveu o tamponamento do sistema, o que obviamente restringe o número de espécies envolvidas no processo. No caso específico da acetonitrila, a coloração exibida pelo cátion foi verde, a qual se manteve por longos períodos (superiores a 20 dias).
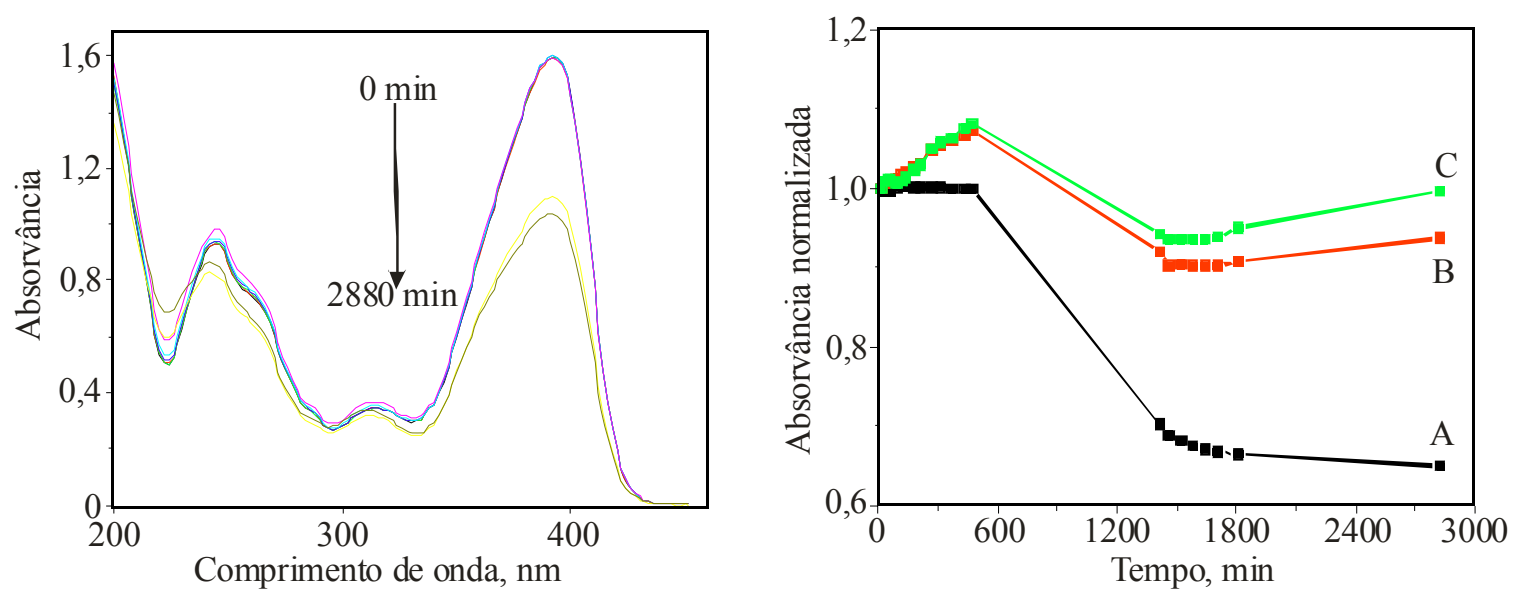

FIGURA 49. (I) espectros de absorção molecular do cátion flavílio em acetonitrila não-tamponada. (II) Absorvâncias normalizadas do cátion flavílio monitoradas a (A) $394 \mathrm{~nm}$, (B) $244 \mathrm{~nm}$ e (C) $314 \mathrm{~nm}$.

Para facilitar a interpretação dos dados obtidos com relação às possíveis espécies presentes em cada sistema estudado, apresentamos na FIGURA 50 os espectros de absorção molecular em meio aquoso. 
Capítulo 6

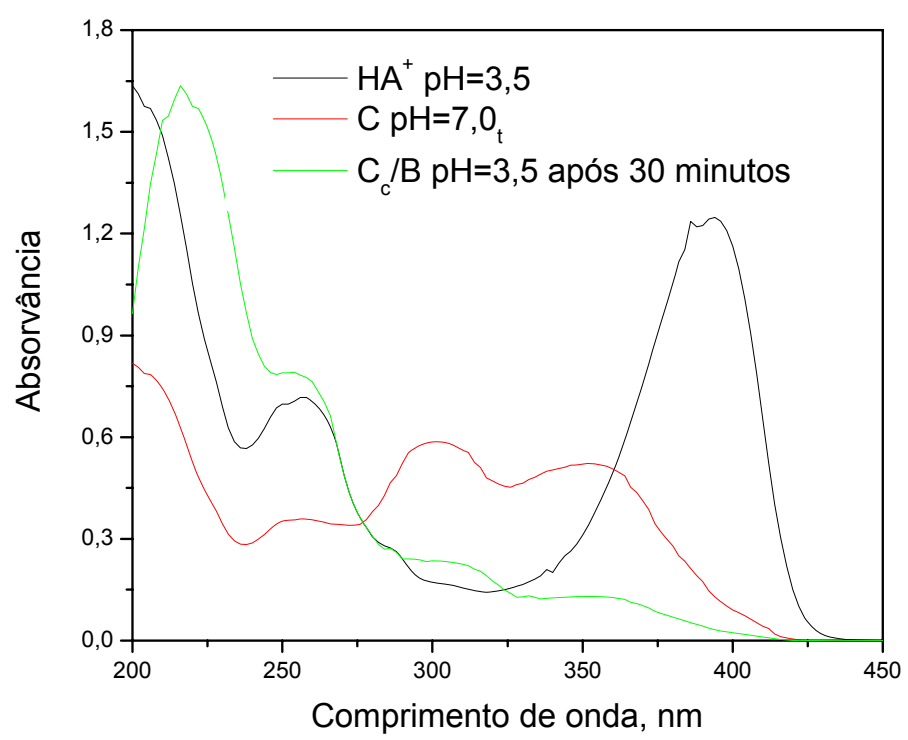

FIGURA 50. Espectros de absorção molecular do cátion flavílio em meio aquoso. $H A^{+}\left(\lambda_{\max }=394 \mathrm{~nm}\right), C_{t}\left(\lambda_{\max }=352 \mathrm{~nm}\right), B\left(\lambda_{\max }=262 \mathrm{~nm}\right), C_{c}\left(\lambda_{\max }=304 \mathrm{~nm}\right)$

Temos focado nossa atenção na estimativa dos tempos de meia-vida e na caracterização da espécie predominante em cada caso. Os valores estimados para os tempos de meia-vida, reportados aqui, correspondem ao tempo necessário para reduzir a absorvância no máximo de absorção à metade.

A seguir, apresentamos os dados obtidos nos experimentos realizados $e$ algumas propriedades físico-químicas dos solventes utilizados. No caso da utilização dos solventes puros, os valores de pKa, permitem ter uma idéia das condições experimentais investigadas. 
TABELA 15. Tempos de meia-vida do cátion flavilio e em diferentes meios de dispersão.

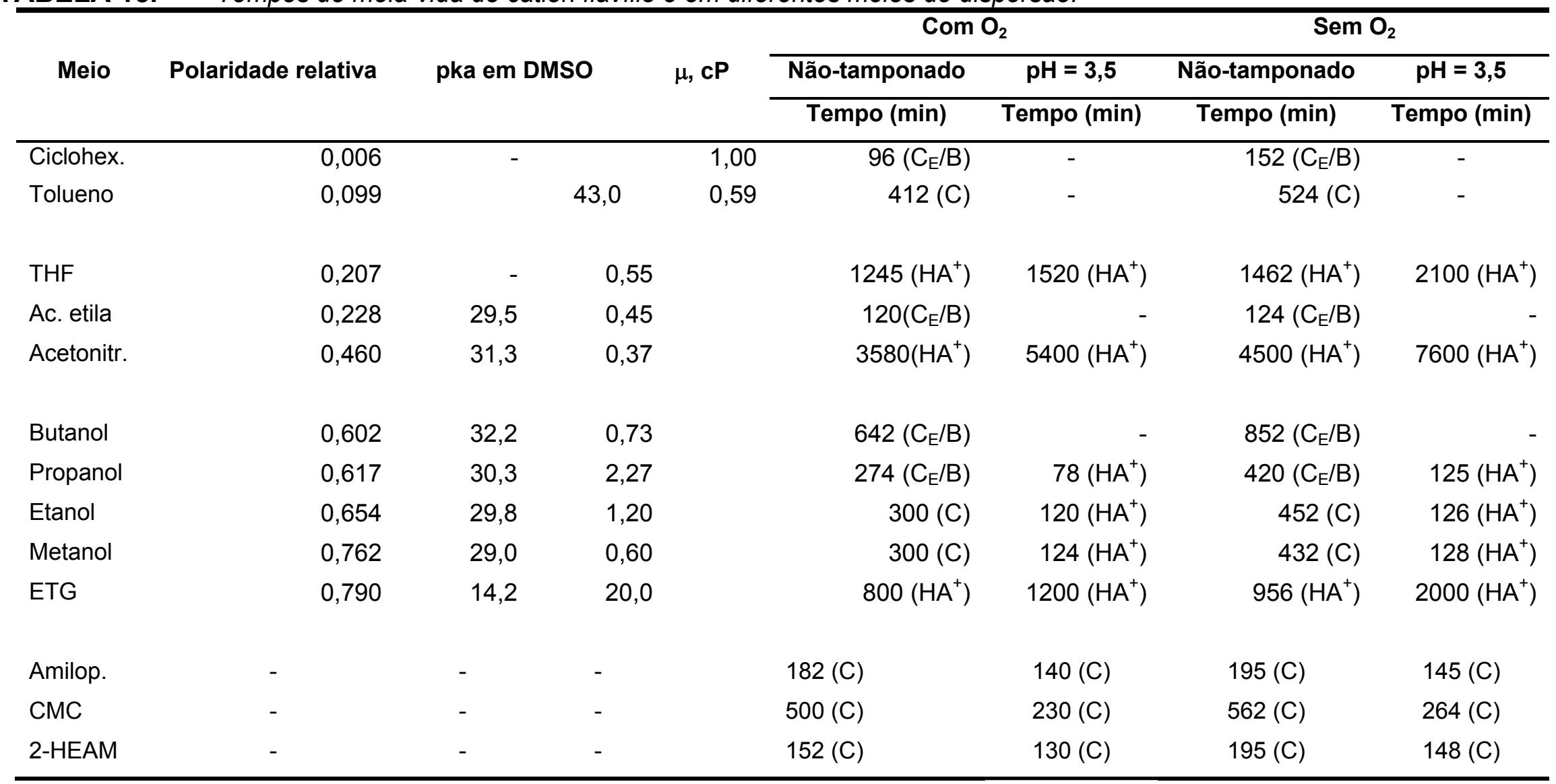

THF = tetrahidrofurano; ETG = etilenoglicol; Amilop. = amilopectina 0,2\% CMC = carboximetilcelulose 0,2\%; 2-HEAM = 2hidroxietilamido $0,2 \%$. 
Capítulo 6

Como não há possibilidade de formação da base quinonoidal devido à ausência de hidroxilas na estrutura do composto, o foco é direcionado ao processo de hidratação do cátion, formando o hemiacetal $(B)$ e posteriormente os isômeros da chalcona $(\mathrm{C})$.

Ao observarmos a TABELA 15 notamos claramente a necessidade em separar os solventes em grupos menores, respeitando as características específicas de suas interações intermoleculares.

Os maiores tempos de meia-vida para o cátion $\left(\mathrm{HA}^{+}\right)$foram obtidos em acetonitrila e tetrahidrofurano, respectivamente. Quando comparamos os dois solventes, observamos o favorecimento na estabilização do cátion em razão do aumento da polaridade do meio. Já em acetato de etila, foi observada a ausência do cátion, apesar da polaridade do meio ser superior à do THF. Neste caso, interações mais específicas devem coordenar o processo de estabilização das espécies, favorecendo neste caso a rápida hidratação do cátion.

Nos solventes de mais baixa polaridade, também notamos a ausência do cátion. Neste caso vale ainda ressaltar que a maior viscosidade do ciclo-hexano em relação ao tolueno demonstra favorecer a presença das formas hemiacetal e dos isômeros da chalcona.

Metanol e etanol favorecem a estabilização da Z-chalcona enquanto propanol e butanol estabilizam as formas E-chalcona e hemiacetal. Especificamente nestes dois últimos solventes, notamos que a menor viscosidade do meio favorece a estabilização das espécies. No grupo dos álcoois, notamos ainda que, apenas em etilenoglicol foi observada a presença do cátion flavílio. A indicação da presença do cátion em etilenoglicol reforça a possibilidade de estabilização do mesmo em biopolímeros polihidroxílicos.

Nos casos onde foi realizado o tamponamento dos sistemas, notamos que a estabilização do cátion aumenta à medida que a viscosidade do meio diminui, exceto em etilenoglicol. Além disso, para os álcoois monohidroxílicos, observamos que a estabilização é favorecida pelo aumento na capacidade de formação de ligações de hidrogênio (maior tempo de meia-vida em metanol). Este dado é interessante para posteriores estudos de copigmentação. A associação das antocianinas com copigmentos ocorre por meio de ligações de hidrogênio ou do processo de 
empilhamento das moléculas mediante interações hidrofóbicas. No caso de empilhamento, proporcionam-se uma eficiente proteção aos cromóforos de antocianinas contra o ataque nucleofílico e, especialmente, a hidratação e perda de cor (MAZZA \& BROUILLARD, 1987; JACKMAN \& SMITH, 1996). Desta forma, a copigmentação é considerada como processo seletivo das formas coloridas (BROUILLARD \& DUBOIS, 1977; BROUILLARD, 1982).

Outro fator a ser considerado na estabilização das espécies diz respeito à desoxigenação dos sistemas. Em todos os casos estudados, observa-se o aumento da estabilidade nas soluções onde o sistema foi desoxigenado. $O$ efeito do oxigênio na degradação de antocianinas foi descoberto por Tressler e Pederson (1989). Eles observaram que a mudança da cor roxa para marrom em sucos engarrafados era prevenida enchendo-se completamente as garrafas, ou seja, eliminando o oxigênio do seu interior. Falcão et al. (2004) verificaram que a presença de nitrogênio aumentou significativamente a estabilidade das antocianinas de uvas (Vitis vinifera $L)$.

Como em meio aquoso as antocianinas formam complexos com numerosos compostos tais como proteínas, taninos, flavonóides não-antociânicos, ácidos orgânicos, ácidos nucléicos, alcalóides, polissacarídios e íons metálicos por meio de copigmentação intermolecular (BROUILLARD \& DELAPORTE, 1977; OSAWA, 1982; ASEN, STEWART \& NORRIS, 1972; SOMERS \& EVANS, 1977; TAMURA, 1998), esperávamos que a espécie em estudo pudesse interagir com os biopolímeros estudados neste trabalho.

A concentração máxima de amilopectina utilizada para o preparo das soluções foi $0,2 \%(\mathrm{~m} / \mathrm{m})$. Concentrações superiores a esta levaram ao turvamento da solução. No caso das soluções de carboximetilcelulose e 2-hidroxietilamido, a mesma concentração foi mantida.

Tanto nas soluções não-tamponadas quanto tamponadas dos biopolímeros, predominaram os isômeros da chalcona. Os maiores tempos de meia-vida foram observados em carboximetilcelulose, o que pode ser justificado pela maior viscosidade do meio. Para todos os três biopolímeros há uma redução no tempo de meia-vida da espécie monitorada. 
Capítulo 6

Algumas antocianinas de vinho tinto foram estabilizadas em ciclodextrinas (CD) (TAMURA, 1998). Os estudos mostraram que diferentemente de ciclodextrinas, os clusters de amilopectina, apesar de seu tamanho favorável para comportar a molécula em estudo, não evita o processo de hidratação do cátion. Somente para comparamos as cavidades de sacarídeos, vale lembrar que CD podem incluir várias substâncias em sua cavidade e formar complexos hóspede-hospedeiro estáveis. Assim, a $\beta-C D$ que possui um diâmetro interno de $8 \AA$ pode incluir por exemplo, uma molécula de naftaleno, enquanto a $\gamma-C D$, com cavidade interna de $10 \AA$ pode comportar duas moléculas de naftaleno. O tamanho da molécula de antocianidinas é de aproximadamente 6 a $12 \AA$ e, segundo Tamura et al. (1998), estas moléculas podem ser incorporadas por $\beta$ - e $\gamma$-CD. Da mesma forma, a cavidade dos clusters de amilopectina apresenta cavidades da ordem de $19 \AA$ (IMBERTY \& PEREZ, 1998), dependendo do processo de preparação das amostras. Contudo, vale lembrar, que o procedimento adotado com pireno e as outras sondas estudadas, não se estende a este caso. Processos de aquecimento, com certeza, favoreceriam o processo de degradação do cátion.

Apesar de não terem sido reportados na TABELA 15, também foram realizados experimentos de estabilização do hemiacetal e da E-chalcona em micelas dos tensoativos não-iônicos, em meio aquoso não-tamponado. Observou-se que os tensoativos estudados nesse trabalho não se mostraram eficientes na estabilização do cátion, favorecendo o processo de hidratação. Os tempos de meia-vida observados foram de 58, 96 e 104 min para Renex 95, Unitol L-70 e Unitol L230, respectivamente, o que pode ser justificado pelas suas estruturas químicas. Um estudo envolvendo a estabilização de antocianinas em meio micelar é apresentado por Mulinacci et al. (2001). Estudando a estabilização de antocianinas em micelas do tensoativo neutro Triton X-100, observaram que o processo de hidratação era favorecido, levando à perda da coloração do sistema. O mesmo fenômeno foi observado para os tensoativos não-iônicos utilizados neste estudo.

Os dados reportados na literatura têm conduzido à conclusão de que a estabilização do cátion é favorecida em tensoativos aniônicos. Um exemplo pode ser dado pelos trabalhos de Sadlowski (1986) demonstrando que um equilíbrio de estabilização de cor da malvina ocorre em soluções micelares de SDS. Sua 
Capítulo 6

sugestão foi que a presença do tensoativo poderia retardar o processo de hidratação quando comparado ao mesmo processo em água pura.

Como resultado preliminar, a presença de luz interferiu negativamente na estabilidade das antocianinas. O tempo de meia vida das amostras (solventes e biopolímero) não foi monitorado, contudo, as alíquotas de solução, quando mantidas na presença de luz, perderam a coloração em intervalos de tempo inferiores a 20 minutos. Gris et al. (2007) verificaram que a luz degradou significativamente as antocianinas de cascas de uvas Cabernet Sauvignon conferindo uma redução do tempo de meia vida de cerca de 50\%. A influência da luz na estabilidade da antocianina cianidina-3-glicosídio arabinosídio isolada da Euphorbia caracasana foi avaliada por Bobbio, Bobbio \& Varella (1994), que verificaram que a presença de luz promoveu diminuição dos valores de tempo de meia vida destes pigmentos. 


\section{CONCULSÕES}

Nesta Tese de Doutorado, comprovou-se a ocorrência de uma interação de associação cooperativa da amilopectina com tensoativos não-iônicos éter dodecil ( 7 e 23)-polioxietilênico (Unitol L-70 e L-230) através de dois métodos distintos de preparo de soluções e aplicando as propriedades de emissão de fluorescência do pireno. Quando se compararam os resultados com outros dois polímeros, verificouse que a associação é menor para os sistemas formados entre os tensoativos e o 2hidroxietilamido e desfavorecidos na presença de carboximetil celulose (CMC).

$\mathrm{O}$ equilíbrio entre as espécies monomérica e excímero do pireno permitiu avaliar os movimentos de rotação e translação da sonda na presença de um polímero altamente ramificado, a amilopectina, e nos complexos amilopectinatensoativo.

O alto grau de ramificação da amilopectina afetou fortemente a solubilização da xantona no interior dos seus agregados, não acontecendo o mesmo com a CMC. Por este motivo, os resultados de fluorescência resolvida no tempo mostraram que conforme a concentração de CMC aumenta, ocorre uma mudança de localização da xantona no seio da solução. Ela passa da solução aquosa para ambientes no interior ou próxima à cadeia polimérica para ser protonada ou não, fornecendo três tempos de vida completamente distintos.

Estudos preliminares sobre a estabilização do cátion 2-fenilbenzopirílio foram realizados nos diversos sistemas de: biopolímeros, complexos polímeros- 
Conclusões

tensoativos, tensoativos não-iônicos puros e solventes. A sua estabilidade foi maior em $\mathrm{CMC}$, devido a presença de cargas negativas no esqueleto polimérico e maior viscosidade da solução. 


\section{REFERÊNCIAS BIBLIOGRÁFICAS}

ADAMO, H. P.; GRIMALDI, M.,E.; BREDESTON, L. M. The N-terminal region of the plasma membrane $\mathrm{Ca} 2+$ pump does not separate from the main catalytic fragments after proteolysis. Biochim. Biophys. Acta. 1464, 127, 2000.

ASEN, S.; STEWART, R. N.; NORRIS, K. H. Copigmentation of anthocyanins in plant tissues and its effect on color. Phytochemistry, 11, 1139, 1972.

ATTWOOD, D. FLORENCE, A.T. Surfactant systems : their chemistry, pharmacy and Biology. 1.ed. Londres: Chapman and Hall, 1983.

AZIZI, M. H.; RAO, G. V., Effect of surfactant in pasting characteristics of various starches. Food Hydrocolloids. 19(4), 739, 2005.

BALDWIN, P. M. Starch granule-associated proteins and polypeptides: a review. Starch. 53(10), 475, 2001.

BANKS, W.; GREENWOOD, C. T. Starch and its components. Edinburg: Edinburgh Univ. Press, 1975, 342.

BARRA, M.; BOHNE, C.; SCAIANO, J. C. Effect of cyclodextrin complexation on the photochemistry of xanthone. Absolute measurement of the kinetics for triplet state exit..J. Am. Chem. Soc., 112, 8075, 1990.

BERTHOD, A.; TOMER, S.; DORSEY, J. G. Polyoxyethylene alkyl ether nonionic surfactants: physicochemical properties and user for cholesterol determination in food. Talanta. 55, 69, 2001.

BHAIRI, S. M. Detergents - a guide to the properties and uses of detergents in biological systems. La Jolla: Calbiochem-Novabiochem Corporation, 2001.

BILIADERIS, C. G. Structures and phase transitions of starch polymers.

Polysaccharide Association Structures in Food, New York, Vol. 87, 57, 1998. 
BILIADERIS, C. G.; SENEVIRATNE, H. D. Solute effects on the thermal stability of glyceryl monostearate-amylose complex superstructures. Carbohydr. Res. 208, 199, 1990.

BILIADERIS, C. G.; TONOGAI, J. R. Influence of lipids on the thermal and mechanical properties of concentrated starch gels. Journal of Agricultural \& Food Chemistry. 39(5), 833, 1991.

BOBBIO, P. A.; BOBBIO, F. O. ; VARELLA, M. T. N. Effect of light and tannic acid on the stability of anthocyanin in DMSO and in water. Food Chem. 51, 183, 1994.

BOHNE, C. Supramolecular Dynamics of Guest Complexation to Cyclodextrins. The Spectrum, 13, 14, 2000.

BOLZ, R. E., and G. L. TUVE. Handbook of Tables for Applied Engineering Science. Boca Raton: CRC Press, 1973.

BONILHA, J.B.S.; NASSAR, P. M.; NOGUEIRA, L.C.; WAISSBLUTH, O.L.; QUINA, F. H. Photophysical probe studies of polymer-detergent interactions. J. Braz. Chem. Soc. 6, 173, 1995.

BOYD, R.W. Nonlinear optics. San Diego: Academic Press, 1992.

BROUILLARD, R. Chemical structure of anthocyanins. In: MARKAKIS, P. (Ed.) Anthocyanins as food colors. New York: Academic Press, 1982. p. 1-39.

BROUILLARD, R.; DELAPORTE, B. Chemistry of anthocyanin pigments. J. Am. Chem. Soc. 99(26), 8461, 1977.

BROUILLARD, R.; DUBOIS, J. E. Mechanism of the structural. transformations of anthocyanins in acidic media. J. Am. Chem. Soc. 99, 1359, 1977.

BUCKINGHAM, A.D.; LIPPERT, E.; BRATOS, S. Organic liquids: structure, dynamics, and chemical properties. New York: Wiley, 1978).

BULÉON, A.; COLONNA, P.; PLANCHOT, V.; Bal, S. Starch granules: structure and biosynthesis. International Journal of Biological macromolecules. 23(2), 85, 1998.

BULPIN, P. V.; CUTLER, A. N.; LIPS, A. Cooperative binding of sodium myristate to amylose. Macromolecules. 20(1), 44, 1987.

BULPIN, P. V.; WELSH, E. J.; MORRIS, E. R. Physical characterization of Amylosefatty acid complexes in starch granules and in solution. Starch/Staerke. 34(10), 335, 1982.

BUNCEL, E.; RAJAGOPAL, S. Solvatochromism and solvent polarity scales. Accounts of Chemical Research, 23, 226, 1990.

CAPITANI, D.; PORROB, F.; SEGREA, A. L. High field NMR analysis of the degree of substitution in carboxymethyl cellulose sodium salt. Carbohydr. Polym. 42(3), 283, 2000. 
CATALAN, C.A.N.; VEGA, M.I.; LOPEZ, M.E.; CUENCA, M.R.; GEDRIS, T.E.; HERZ, W. Coumarins and a kaurane from Gochnatia polymorpha ssp polymorpha from Paraguay. Biochem Syst Ecol. 31,417, 2003.

CHO, J. K.; AZUMA, N.; LEE, C. H.; YU, J. H.; KANNO, C. Purification of membranebound lactoferrin from the human milk fat globule membrane. Biosc. Biotechnol. Biochem. 64, 633, 2000.

CLIFFORD, M. N. Chlorogenic acids and other cinnamates-nature, occurrence. J. Sc. Food and Agriculture 80,1033, 2000.

CLOTHIER, J. G.; TOMELLINI, S. A. Chiral separation of verapamil and related compounds using micellar electrokinetic capillary chromatography with mixed micelles of bile salt and polyoxyethylene ethers. J. Chromatog. A. 723, 179, 1996.

COLLISON, R. Starch retrogradation. In RADLEY, J. R. Starch and its derivatives. London: Chapman and Hall, 1968, p.194.

DEBET, M. R.; GIDLEY, M. J. Three classes of starch granule swelling: influence of surface proteins and lipids. Carbohydrate Polymers. 64(3), 452, 2006.

DEFFENBAUGH, L. B.; WALKER, C. E. Use of the Rapid Visco-Analyzer to measure starch pasting properties. Part II: effects of emulsifiers and sugar-emulsifier interactions. Starch. 42(3), 89, 1990.

DONALD, A. M.; WAIGH, T. A.; JENKINS, P. J.; GIDLEY, M. J.; DEBET, M.; SMITH, A. Internal structure of starch granules revealed by scattering studies. Special Publication - Royal Society of Chemistry. 205, (Starch), 172, 1997.

DONG, D.C.; WINNIK, M.A. The py scale of solvent polarities. solvent effectson the vibronic fine structure of pyrene fluorescence and empiricalcorrelations with $E t$ and $Y$ values. Photochem. Photobiol. 35, 17, 1982.

ELIASSON, A. C. Starch-lipid interactions studied by differential scanning calorimetry. Thermochimica Acta. 95(2), 369, 1985.

ELIASSON, A. C.; FINSTAD, H.; LJUNGER, G. A study of starch-lipid interactions for some native and modified maize starches. Starch. 40(3), 95, 1988.

ELIASSON, A. C.; KROG, N. Physical properties of amylose-monoglyceride complexes. Journal of Cereal Science. 3(3), 239,1985.

ELIASSON, A.C. Interactions between starch lipids studied by DSC. Thermochemica Acta. 246, 343, 1994.

ELIASSON, A.C. On the effects of surface active agents on the gelatinization of starch - a calorimetric investigation. Carbohydrate Polymers. 6(6), 463, 1986.

ELIASSON, A.-C. Starch gelatinization in the presence of emulsifiers. A morphological study of wheat starch. Starch. 37(12), 411, 1985. 
ELIASSON, A.-C.; LARSSON, K. Cereals in breadmaking: a molecular colloidal approach. New York: Marcel Dekker, 1993; p.376.

ESMANN, M.; SKOU, J. C. Kinetic properties of C12E8 solubilized (Na+ + K+)ATPase. Biochim. Biophys. Acta. 787, 71, 1984.

ESPIN, J. C.; SOLER-RIVAS, C.; WICHERS, H.; GARCIA-VIGUERA, C. Anthocyanin-based natural colorants: a new source of antiradical activity for foodstuff. J. Agric. Food Chem. 48,1588, 2000.

EVANS, C. H.; PRUD'HOMME, N.; KING, M.; SCAIANO, J. C. Calibration of the triplet-triplet absorption of xanthone as a microenvironment sensor. J. Photochem. Photobiol. A: Chemistry, 121, 105, 1999.

EVANS, I. D. An investigation of starch/surfactant interactions using viscosimetry and differential scanning calorimetry. Starch. 38(7), 227, 1986.

EVANS, I. D.; HAISMAN, D. R. The effect of solutes on the gelatinization temperature range of potato starch. Starch. 34(7), 224, 1982.

FALCÃO, L.D.; GAUCHE, C.; BARROS, D. M. ; PRUDÊNCIO, E. S. ; GRIS, E. F. ; SANT'ANNA, E.S.; OGLIARI, P.J.; LUIZ, M.T.B. stability of anthocyanins from grape (vitis vinifera I.) Skins with tannic acid in a model system. Italian J. Food Sci. 16(3), 323, 2004.

FENDLER, J.H. Membrane mimetic chemistry. New York: Wiley, 1982.

FORSTER, T.; KASPER, K.Z. Ein Konzentrationsumschlag Der Fluoreszenz Des Pyrens . Elektrochem. 59(10), 976, 1955.

FREITAS, A. A.; PAULO, L.; MAÇANITA, A. L.; QUINA, F. H. Acid-base equilibria and dynamics in sodium dodecyl sulfate micelles: Geminate recombination and effect of charge stabilization. Langmuir. 22, 7986, 2006.

FRENCH, A. D.; MURPHY, V. G. Computer moldeling in the study of starch. Cereal Foods World. 22, 61, 1977.

FRENCH, D. Organisation of starch granules. In Starch: chemistry and technology, WHISTLER, R. L.; BEMILLER, J. N.; PASCHALL, E. F., Eds. Orlando: Academic Press, 1984.

FRENCH, D.; PULLEY, A. O.; WHELAN, W. J. Starch fractionation by hydrophobic complex formation. Staerke. 15, 349, 1963.

GALEMBECK, E.; ALONSO, A.; MEIRELLES, N. C. Effects of polyoxyethylene chain lenght on erythrocyte hemolysis induced by poly[oxyethylene $(n)$ nonyphenol] nonionic surfactants. Chem. Biol. Inter. 113, 91, 1998.

GHIASI, K.; VARRIANO-MARSTON, E.; HOSENEY, R. C. Gelatinization of wheat starch. II. Starch-surfactant interaction. Cereal Chemistry. 59(2), 86, 1982. 
GIDLEY, M. J.; BULPIN, P. V. Aggregation of amylose in aqueous systems: the effect of chain length on phase behavior and aggregation kinetics. Macromolecules. 22(1), 341, 1989.

GIESTAS, L.; YIHWA, C.; LIMA, J. C.; VAUTIER-GIONGO, C.; LOPES, A.; MAÇANITA, A. L.; QUINA, F. H. The dynamics of ultra-fast excited state proton transfer in anionic micelles. J. Phys. Chem. A. 107, 3263, 2003.

GILBERT, A.; BAGGOTT, J. Essentials of molecular photochemistry. Oxford: Blackwell Scientific Publications, 1991.

GODET, M. C.; BULLEÓN, A.; TRAN, V.; COLONNA, P. Structural features of fatty acid amylose-complexes. Carbohydrate Polymers. 21, 91, 1993.

GODET, M. C.; TRAN, V.; COLONNA, P.; BULEON, A.; PEZOLET, M. Inclusion/exclusion of fatty acids in amylose complexes as a function of the fatty acid chain length. International Journal of Biological Macromolecules. 17(6), 405, 1995.

GRIS,E.F.; FERREIRA,E.A.; FALCÃO,L.D.; BORDIGNON-LUIZ, M.T. Caffeic acid copigmentation of anthocyanins from Cabernet Sauvignon grape extracts in model systems. Food Chem., 100(3), 1289, 2007.

GRUEN, D.W.R. The standard picture of ionic micelles. Progr. Colloid. Polym. Sci. 70, 6, 1985.

HARTLEY, G.S. Aqueous solution of paraffin-chain salts. Kolloid-Z. 88, 22, 1939.

HIEMENZ, P.C.; RAJAGOPALAN, R. Principles of colloid and surface chemistry. New York: Marcel Dekker, 1986

IMBERTY, A.; PEREZ, S. Conformational analysis and molecular modelling of the branching point of amylopectin. International journal of biological macromolecules. 11(3), 177, 1989.

IRELAND, J. F.; WYATT, A. H. Excited singlet and triplet pK values of xanthone in aqueous solution. J. Chem. Soc. Faradays Trans. 68, 1053, 1972.

JABLONSKI, A. Efficiency of anti-Stokes fluorescence in dyes. Nature. 131, 839, 1933.

JACKMAN, R. L.; SMITH, J. L. Anthocyanins and betalains. In: HENDRY, G. A. F.; HOUGHTON, J. D. (Eds.) Natural food folorants. 2.ed. Londres: Chapman \& Hall, 1996.

JANE, J. L. Structure studies of amylose-V complexes and retrograded amylose by action of alpha amylases, and a new method for preparing amylodextrins. Carbohydr Res. 132(1), 105, 1984.

JENKINS, P. J.; DONALD, A. M. Gelation of starch: a combined SAXS/WAXS/DSC and SANS study. Carbohydrate Research. 308(1-2), 133, 1998. 
JUNGERMANN, E. Cationic Surfants. In: Surfactant Science Series. New York: Marcel Dekker, 1970.

Kalyanasundaram, K. Photochemistry in Microheterogeneous Systems; Academic Press: Orlando, 1987.

KALYANASUNDARAM, K.; THOMAS, J.K. Environmental effects on vibronic band intensities in pyrene monomer fluorescence and their application in studies of micellar systems. J. Am. Chem. Soc., 99, 2039, 1977.

KAMLET, M. J.; ABBOUD, J. L. M.; TAFT, R. W. An examination of linear solvation energy relationships. Prog. Phys. Org. Chem., 13, 485, 1981.

KARKALAS, J.; MA, S.; MORRISON, W. R.; PETHRICK, R. A. Some factors determining the thermal properties of amylose inclusion complexes with fatty acids. Carbohydrate Research. 268(2), 233, 1995.

KONG, J. M.; CHIA, L.; GOH, N.; CHIA, T.; BROUILLARD, R. Analysis and biological activities of anthocyanins Phytochemistry. 64, 923, 2003.

KOSOWER, E. M. The Effect of Solvent on Spectra. I. A New Empirical Measure of Solvent Polarity: Z-Values. J. Am. Chem. Soc., 80, 3253, 1958.

KOWBLANSKY, M. Calorimetric investigation of inclusion complexes of amylose with long-chain aliphatic compounds containing different functional groups.

Macromolecules. 18(9), 1776, 1985.

KROG, N. Influence of food emulsifiers on pasting temperature and viscosity of various starches. Starch. 25(1), 22, 1973.

LAKOWICZ, J. R. Principles of fluorescence spectroscopy. 2.ed. New York: Kluwer Academic/Plenum Publishers, 1999.

Le MAIRE, M.; CHAMPEIL, P.; MOLLER, J. V. Interaction of membrane proteins and lipids with solubilizing detergents. Biochim. Biophys. Acta. 1508, 86, 2000.

LeROSEN, A. L.; REID, C. E. An Investigation of Certain Solvent Effect in Absorption Spectra. J. Chem. Phys., 20, 233, 1952.

LINDMAN,B. In: TRADOS, T.F. Surfactants. Londres: Academic Press, 1984.

LINFIELD, W.M. Anionic Surfactants. In: Surfactant Science Series. New York: Marcel Dekker, 1976.

LIVESEY, A. K.; BROCHON, J. C. Analyzing the Distribution of Decay Constants in Pulse-Fluorimetry Using the Maximum Entropy Method . Biophys. J. 52, 693, 1987.

LUNDQVIST, H.; ELIASSON, A.-C.; OLOFSSON, G. Binding of hexadecyltrimethylammonium bromide to starch polysaccharides. Part I. Surface tension measurements. Carbohydrate Polymers. 49(1), 43, 2002. 
LUNDQVIST, H.; ELIASSON, A.-C.; OLOFSSON, G. Binding of hexadecyltrimethylammonium bromide to starch polysaccharides. Part II. Calorimetric study. Carbohydrate Polymers. 49(2), 109, 2002.

LUNDQVIST, H.; NILSSON, G. S.; ELIASSON, A.-C.; GORTON, L. Changing the amylopectinsodium dodecyl sulfate interaction by modifying the exterior chain length. Starch/Staerke. 54(3-4), 100, 2002.

MARKAKIS, P. Stability of anthocyanins in foods. In: MARKAKIS, P. (Ed.) Anthocyanins as food colors. New York: Academic Press, 1982.

MATAGA, N.; KAIFU, Y.; KOIZUMI, M. Solvent effects upon fluorescence spectra and the dipole-moments of excited molecules. Bull. Chem. Soc. Jpn. 29, 465, 1956.

MAZZA, G.; BROUILLARD, R. Recent developments in the stabilization of anthocyanins in food products. Food Chem. 25, 207, 1987.

MAZZA, G.; MINIATI, E. Anthocyanins in fruits, vegetables and grains. Boca Raton: CRC Press, 1993.

MIKUS, F. F.; HIXON, R. M.; RUNDLE, R. E. Complexes of fatty acids with amylose. J. Am. Chem. Soc. 68, 1115, 1946.

MILES, M. J.; MORRIS, V. J.; RING, S. G., Some recent observations on the retrogradation of amylose. Carbohydrate Polymers 1984, 4, (1), 73-77.

MIRANDA, J.A.; CACITA, N.; OKANO, L.T. Evaluation of Amylopectin Clusters and Their Interaction with Nonionic Surfactants Colloid Surf. B, 60, 19, 2007.

MITCHELL, W. A. Starch solubility. J. Chem. Educ. 54, 132, 1977.

MOROI, Y. Micelles: theoretical and applied aspects. New York: Plenum Press, 1992.

MORRISON, W. R. Starch lipids: a reappraisal. Starch/Staerke. 33(12), 408, 1981.

MULINACCI, N.; ROMANI, A.; PINELLI, P.; GALLORI, S.; GIACCHERINI, C.; Vincieri, F.F. Stabilization of natural anthocyanins by micellar systems. Intern. J. Pharmaceutics 216, 23, 2001

MUROV, S. L.; CARMICHAEL, I.; HUG, G. L. Handbook of photochemistry, 2nd, revised and expanded ed. New York: Marcel Dekker, 1993.

MURPHY, R. S.; BARROS, T. C.; BARNES, J.; MAYER, B.; MARCONI, G.; BOHNE, C. Complexation of Fluorenone and Xanthone to Cyclodextrins: Comparison of Theoretical and Experimental Studies. J. Phys. Chem. A. 103, 137, 1999.

MYERS, D. Surfaces, interfaces and colloids: principles and applications. 2.ed. New York: Wiley-VCH, 1999.

NAGANINE, T.; KOMAE, K. Improvement of a method for chain-length distribution analysis of wheat amylopectin. J. Chromatogr. A. 732, 255, 1996. 
NAKAJIMA, A. Solvent effect on the vibrational structures of the fluorescence and absorption spectra of pyrene. Bull.Chem.Soc.Jpn., 44, 3272, 1971.

NIERLE, W.; EI BAYA, A. W. Lipids and rheological properties of starch. Part I: the effect of fatty acids, monoglycerides and monoglyceride ethers on pasting temperature and viscosity of wheat starch. Starch. 42(7), 268, 1990.

NIERLE, W.; EI BAYA, A. W.; KERSTING, H. J.; MEYER, D. Lipids and rheological properties of starch. Part II: the effect of granule surface material on viscosity of wheat starch. Starch/Staerke. 42(12), 471, 1990.

NOEL, T. R.; RING, S. G.; WHITMAN, M. A. Physical properties of starch products: structure and function. In Food colloids and polymers: stability and mechanical properties, DICKINSON, E.; WALSTRA, P., Eds. Cambridge: Royal Society of Chemistry, 1993.

NORONHA, M.; LIMA, J. C.; LAMOSA, P.; SANTOS, H.; MAYCOCK, C.; VENTURA, R.; MAÇANITA, A. L. Intramolecular Fluorescence Quenching of Tyrosine by the Peptide -Carbonyl Group Revisited. J. Phys. Chem. A. 108, 2155, 2004.

OKANO, L. T.; BARROS, T. C.; CHOU, D. T. H.; BENNET, A. T.; BOHNE, C. Complexation Dynamics of Xanthone and Thioxanthone to beta-Cyclodextrin Derivatives. J. Phys. Chem. B, 105, 2122, 2001.

OSAWA, Y. Copigmentation of anthocyanins. In: MARKAKIS, P. (Ed.) Anthocyanins as food colors. New York: Academic Press, 1982. p. 41-67.

PAINELLI, A., TERENZIANI, F. A non-perturbative approach to solvatochromic shifts of push-pull chromophores. Chem. Phys. Lett. 312, 211, 1999.

PALAMIDIS, N.; MARKAKIS, P. Stability of grape anthocyanin. in a carbonated beverage. J. Food Sci. 40, 1047, 1975.

PARKER, R.; RING, S. G. Aspects of the physical chemistry of starch. Journal of Cereal Science. 34(1), 1, 2001.

PAULO, L.; FREITAS, A. A.; da SILVA, P. F.; SHIMIZU, K.; QUINA, F. H.; MAÇANITA, A. L. Ground- and excited-state prototropic reactivity of a hydroxycarboxyflavylium salt. J. Phys. Chem. A 110, 2089, 2006.

RAPHAELIDES, S.; KARKALAS, J. Thermal dissociation of amylose-fatty acid complexes. Carbohydrate Research. 172(1), 65, 1988.

REICHARDT, C. Solvents and solvents efects in organic chemistry. 2.ed. Cambridge: Weinhein, 1988.

REICHARDT, C. Solvochromic dyes as solvent polarity indicators. Chem. Rev. 94, 2319, 1994.

REICHARDT, C; HARBUSCH-GORNET, E. Liebigs Ann. Chem. 1983, 5, 721. 
RICHARDSON, G.; LANGTON, M.; BARK, A.; Hermansson, A.-M. Wheat starch gelatinization- The effects of Sucrose, emulsifier and the Physical state of the emulsifier. Starch. 55, 150, 2003.

RIDOUT, M. J.; GUNNING, A. P.; PARKER, M. L.; WILSON, R. H.; MORRIS, V. J. Using AFM to image the internal structure of starch granules. Carbohydrate polymers. 50, 123, 2002.

ROACH, R. R.; HOSENEY, R. C. Effect of certain surfactants on the swelling, solubility and amylograph consistency of starch. Cereal Chemistry. 72(6), 571, 1995.

RODRIGUES, R.; VAUTIER-GIONGO, C.; da SILVA, P. F.; FERNANDES, A. C.; CRUZ, R.; MAÇANITA, A. L.; QUINA, F. H. Geminate proton recombination at the surface of sds and ctac micelles probed with a micelle-anchored anthocyanin.

Langmuir. 22, 933, 2006.

SADLOWSKI, E.S. pH dependent anthocyanin reactions in micellar and copigmented solutions. Dissertation Abstr. Int. 47(4), 1579, 1986.

SCAIANO, J. C. Solvent effects in the photochemistry of xanthone. J. Am. Chem. Soc., $102,7747,1980$.

SCHICK, M.J. Noionic surfactants. In: Surfactant Science Series. New York: Marcel Dekker, 1967.

SCHNEIDER, D. P.; SCHMIDT, M.; HASINGER, G.; LEHMANN, I.; GUNN, J.E.; GIACCONI, R.; TRÜMPER, J.; ZAMORANI, G. Discovery of an X-Ray-selected Quasar with a Redshift of 4.45. The Astronomical Journal. 115, 1230, 1998.

SHAW, D. J. Introdução à química dos colóides e de superfícies - trad. Juergen Hunrech Maar. São Paulo: Edgard Blücher, 1975.

SHEN, Y.R. The principles of nonlinear optics. New York: John Wiley \& Sons, 1984.

SOMERS, T. C.; EVANS, M. E. Grape pigment phenomena: Interpretation of major colour losses during vinification. J. Sci. Food Agric. 28, 279, 1977.

STIGTER, D. On the adsorption of counterions at the surface of detergent micelles. J. Phys. Chem. 68, 3603, 1964.

STRIKER, G.; SUBRAMANIAM, V.; SEIDEL, C. A. M.; VOLKMER, A. Photochromicity and fluorescence lifetimes of green fluorescent protein. J. Phys.

Chem. B. 103, 8612, 1999.

SUPPAN, P.; GHONEIM, N. Solvatochromism. Cambridge: The Royal Society of Chemistry, 1997

SVENSSON, E.; AUTIO, K.; ELIASSON, A.C. The effect of sodium dodecylsulfate on gelatinisation and gelation properties of wheat and potato starches. Food

Hydrocolloids. 12, 151, 1998. 
SVENSSON, E.; GUDMUNDSSON, M.; ELIASSON, A.-C. Binding of sodium dodecylsulphate to starch polysaccharides quantified by surface tension measurements. Colloids and surfaces B: Biointerfaces. 9, 227, 1996.

TAKAHASHI, S.; SEIB, P. A. Paste and gel properties of prime corn and wheat starches with and without native lipids. Cereal Chemistry. 65(6), 474, 1988.

TAKEO, K.; TOKUMURA, A.; KUGE, T. Complexes of starch and its related materials with organic compounds. X. X-ray diffraction of amylose-fatty acid complexes.

Staerke. 25(11), 357, 1973.

TAMURA, $\mathrm{H}$. et al. The color stability and antioxidative activity of an anthocyanin and Y-cyclodextrin complex. In: SHIBAMOTO, T.; TERAO, J.; OSAWA, T. Functional Foods for Disease Prevention 1: Fruits, Vegetables and Teas, San Francisco: American Chemical Society, 1998, cap. 16, p.157-171.

TANFORD, C. Physical chemistry of macromolecules. New York: John Willey \& Sons, 1961

TERPETSCHNIG, E.; JAMESON, D.M. Fluorescence Lifetime. Disponível em: <http://www.iss.com/resources/tech1/index.html>. Acesso em: 19 de jul. de 2007.

TESTER, R. F.; KARKALAS, J.; Qi, X. Starch-composition, fine structure and architecture. Journal of Cereal Science. 39(2), 151, 2004.

TESTER, R.; MORRISON, W. R. Swelling and gelatinization of cereal starches. I. Effects of amylopectin, amylose, and lipids. Cereal Chemistry. 67(6), 551, 1990.

TOUSO, A. T. Estudo da interação da xantona nos agregados de derivados de celulose e tensoativo. Dissertação de Mestrado, Universidade de São Paulo, 2003.

TRESSLER, D. K.; PEDERSON, C. S. Preservation of grape juice. I. Pasteurization of Concord grape juice. Food Research. 1, 9, 1936

TUFVESSON, F.; WAHLGREN, M.; ELIASSON, A.-C. Formation of amylose-lipid complexes and effects of temperature treatment. Part 1. Monoglycerides.

Starch/Staerke. 55(2), 61, 2003.

TUFVESSON, F.; WAHLGREN, M.; ELIASSON, A.-C. Formation of amylose-lipid complexes and effects of temperature treatment. Part 2. Fatty acids. Starch/Staerke. 55(3-4), 138, 2003.

TURRO, N. J. Modern molecular photochemistry. New York: University Science Books, 1991

VALEUR, B. Molecular fluorescence: principles and applications. Weinheim: WileyVCH Verlag GmnH, 2001.

VASANTHAN, T.; HOOVER, R. A comparative study of the composition of lipids associated with starch granules from various botanical sources. Food Chemistry. 43(1), 19, 1992. 
Von LIPPERT, E. Spectroskopische bestimmung des dipolomomentes aromatischer verbindugen im ersten angeregten singulettzustand. Z. Electrochem, 61, 962, 1957.

WAIGH, T.A.; KATO, K.L.; DONALD, A.M.; GIDLEY, M.J.; CLARKE, C.J.; RIEKEL, C. Side-chain liquid-crystalline model for starch. Starch-Starke. 52, 450, 2000.

WAIGH, T.A.; PERRY, P.A.; RIEKEL, C.; GIDLEY, M.J.; DONALD, A.M. Chiral side chain liquid crystalline properties of starch. Macromolecules. 31, 7980, 1998.

WANG, H.; CAO, G.; PRIOR, R. Oxigen radical absorbing capacity of anthocyanins J. Agric. Food Chem. 45, 304, 1997.

YAMAMOTO, A.; LUO, A. M.; DODDA-KASHI, S.; LEE, V. H. L. The ocular route for systemic insulin delivery in the albino rabbit. J. Pharmacol. Exp. Ther. 249, 249, 1989.

YAMAMOTO, M.; SANO, T.; HARADA, S.; YASUNAGA, T. Cooperativity in the binding of sodium dodecyl sulfate to amylose. Bulletin of the Chemical Society of Japan. 56(9), 2643, 1983.

YAMAMOTO, M.; SANO, T.; YASUNAGA, T. Interaction of amylose with iodine. I. Characterization of cooperative binding isotherms for amyloses. Bulletin of the Chemical Society of Japan. 55(6), 1886, 1982.

YANG, C.; MENG, B.; LIU, X.; CHEN, M.; HUA, Y.; NI, Z. Dynamics of amylopectin in semidilute aqueous solution . Polymer, 47, 8044, 2006.

ZAGO NETO, O. G.; Del PINO, J. C. Trabalhando a química dos sabões e detergentes. Apostila do Instituto de Química da UFRS, v.1, 2006.

ZANA, R. J. Ionization of cationic micelles: effect of the detergent structure. Colloid Interface Sci. 78, 330, 1980.

ZHONG, F.; YOKOYAMA, W.; WANG, Q.; SHOEMAKER, C. F. Rice Starch, Amylopectin, and Amylose: Molecular Weight and Solubility in Dimethyl SulfoxideBased Solvents. J. Agric. Food Chem. 54, 2320, 2006.

ZOBEL, H. F. Molecules to granules: a comprehensive starch review. Starch. 40(2), $44,1988$. 